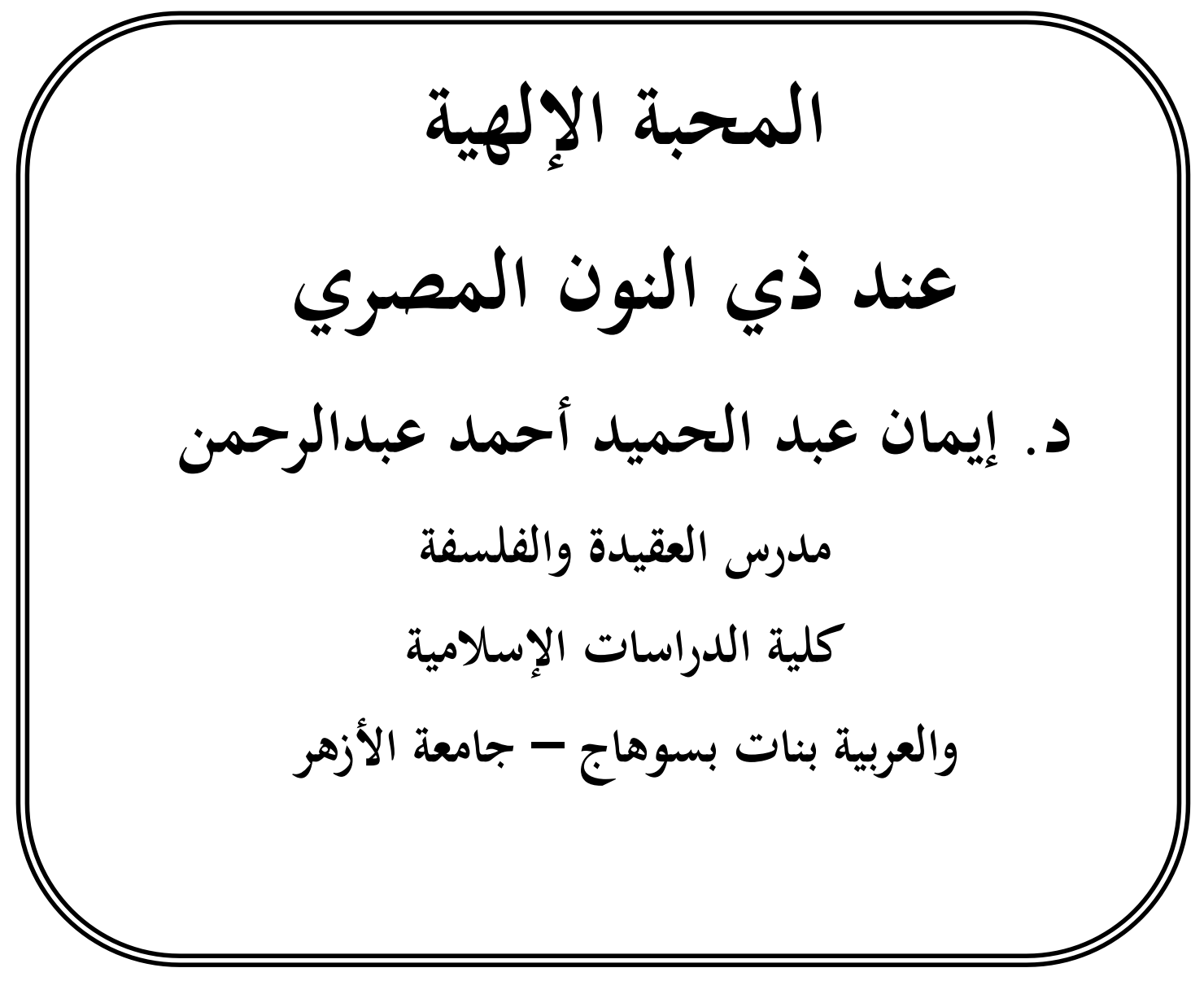





\section{ملخص بحث}

تناول هذا البحث " المحبة الإلهية عند ذي النون المصري " في القرن الثالث الهجري (التاسع الميلادي) ظهر رجال عرفوا بنظريات في المحبة الإلهية ، منهم ذو النون

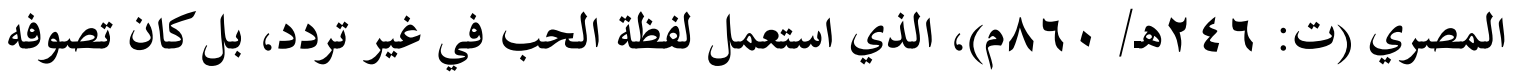
في قوامه يقوم على المحبة الإلهية التي هي روح التصوف والحال المشتركة بين المتصوفة جميعًا، هي بداية البداية، ونهاية النهاية بل ان تلك المحبة هي الزاد للصوفي في طريقه إلى الله.

بل تعد المحبة الإلهية من أعلى مقامات العارفين، وهي إيثار من الله لعباده المخلصين، وفضل منه تعالى عظيم، فما بعد إدراك المحبة مقام إلا وهو ثمرة من ثمارها، وتابع من

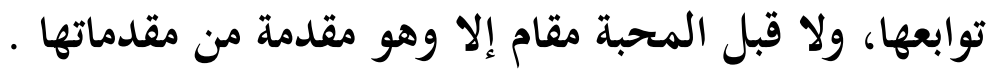
وقد تناولت المحبة الإلهية عند ذي النون المصري ، واستنطتها من أقواله وأشعاره، وانتهيت من ذلك بوجود نظرية المحبة الإلهية عنده وهي لا تقل أهمية عمن سبقه في ذلك.

وجاء البحث في عدة نقاط على النحو الآتي: تعريف بذي النون، نشأته وحياته العلمية،

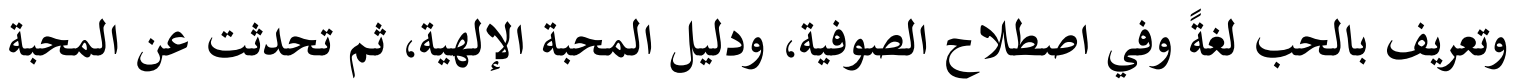
عند ذي النون وعلاماتها، وصفات المحبين ودرجاتهم عند ذي النون، كما ذكرت استعماله للرمزية في التعبير عن المحبة الإلهية، ثم تناولت علاقة المحبة ببعض الأحوال

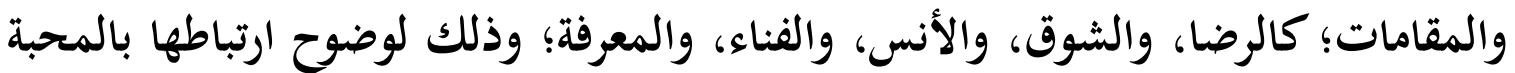
في عبارات ذي النون، ولما لها من تأثير وتأثر بالمحبة الإلهية عنده، وأخيرًا ذكرت نماذج من مشاهدات ذي النون للمحبين، ثم أنهيت البحث بخاتمة أوضحت فيها مدى أهمية المحبة الإلهية في تصوف ذي النون المصري. 


\section{Abstract}

Dhul-Nun al-Misri's Love of God This paper sheds light on the concept of Love of God in Dhul-Nun al-Misri's thought. In the thirteenth Hijri century, a group of men emerged as lovers of God, and Dhul-Nun al-Misri (Died 642 H/820 AD) is just one of them. He uses the word "love" unhesitantly, and as a matter of fact his mystic though is based on love of God which is the essence of mysticism, and a common conceptualization among all mystic figures. Love of God, for mystics, is the beginning and the end, it's the mystic's support on the path of God, one of the highest spiritual ranks, a favor from God to the devoted believers, and a great honor. There is nothing beyond realizing this Godly love unless it's one of its fruits and a consequence, and there nothing comes before it unless it's an introduction to it.

I have studied Dhul-Nun al-Misri's love of God, deducting it from his poetry and sayings and have come to the conclution that his theory of love of God is not less significant than his predecessors.

The paper sheds light on the following: a biography of Dhul-Nun al-Misri and a synopsis about his life and contributions, linguistic and mystic definitions of love, proofs of Godly love, Dhul-Nun al- Misri's concept of love, signs of that love, and characteristics and ranks of lovers. I have also highlighted his use of symbolism to express love of God, and how love relates to certain conditions and ranks like satisfaction, missing, affability, evanescence, knowledge, which are obviously relevant and effective concepts to love for DhulNun al-Misri. Finally, I have presented models of Dhul-Nun alMisri's observations of lovers of God. In the conclusion, I reflect upon the significance of love of God in Dhul-Nun alMisri's model of mysticism. 


\section{مقدمة}

الحمد الله مسبغ النعم، ومتمم الفضل، ومحيي القلوب، وصلاةً وسلامًا على الحبيب

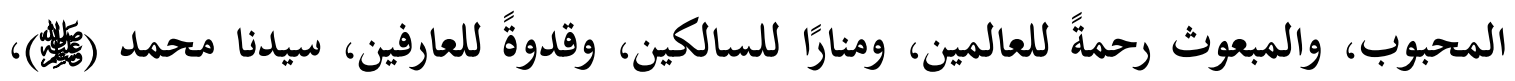
وعلى آله وصحبه والتابعين إلى يوم الدين.

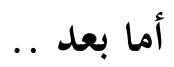

فإن المحبة هي أسمى وأرقى العلاقات في الوجود، تأتي نتيجة صفاء القلب ونقائه مما فيه من شوائب مختلفة الألوان، وفيها المحب يمنح أغلى ما لديه وأشرف ما يملكه لمحبوبه، وهو روحه التي بين جنبيه.

والمحبة الإلهية هي روح التصوف والحال المشتركة بين المتصوفة جميعًا، هي بداية البداية، ونهاية النهاية بل هي الزاد للصوفي في طريقه إلى اللى الله. كما أن المحبة الإلهية من أعلى مقامات العارفين، وهي إيثار من الله لعباده المخلصين، وفضل منه تعالى عظيم، فما بعد إدراك المحبة مقام إلا وهو ثمرة من ثمارها، وتابع من توابعها، ولا قبل المحبة مقام إلا وهو مقدمة من مقدماتها.

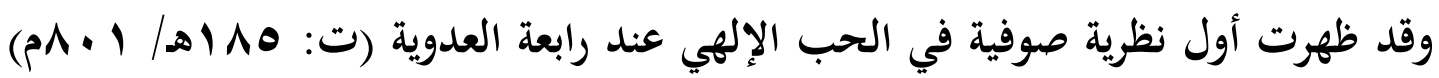

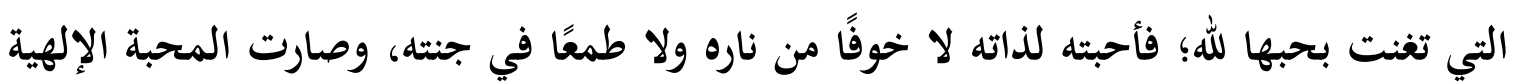
من بعد رابعة المحور الذي تدور عليه الحياة الصوفية، والهدف الذي تتجه إليه. وظهر في القرن الثالث الهجري (التاسع الميلادي) خاصةً رجال عرفوا بنظريات في المحبة

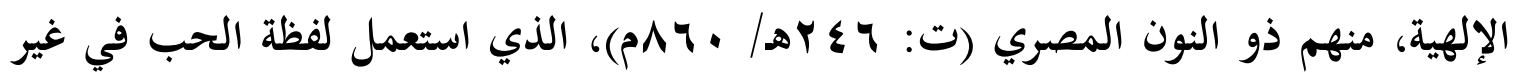
تردد، بل كان تصوفه في قوامه يقوم على المحبة الإلهية، التي هي محور موضوع هذا البحث الذي بصدده.

وسوف أتناول في هذا البحث " المحبة الإلهية عند ذي النون المصري " . وقد وقع اختياري لهذا الموضوع لأن المحبة الإلهية لم تُبحث من قبل بشكل منفرد عند ذي النون، بل إن الكتابات السابقة كانت تتحدث عن تصوف ذي النون، مع إشارات مقتضبة 
عن المحبة الإلهية عنده، اقتضتها ضرورة تلك الكتابات، لذا حرصت على السير في هذا الموضوع ، وجمع أطرافه، وبحثه في دراسة مستقلة بذاتها تبين أهميته.

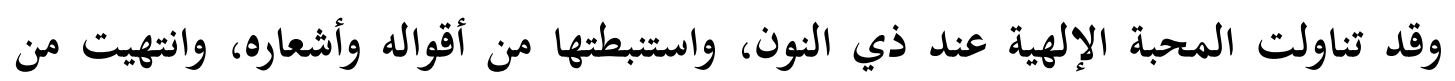

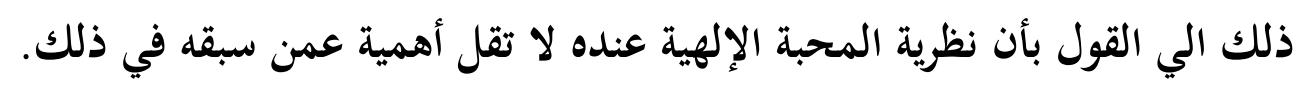

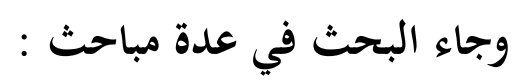

المبحث الاول : التعريف بذي النون، نشأته وحياته العلمية .

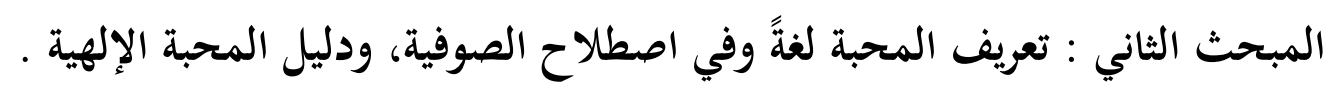

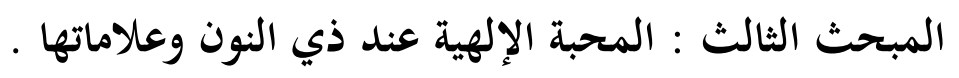

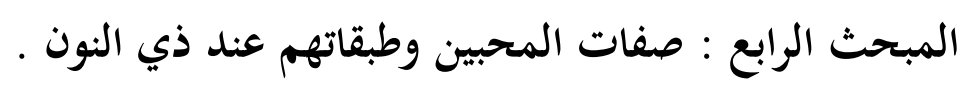

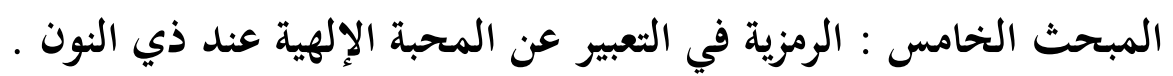

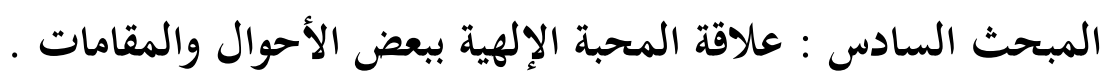

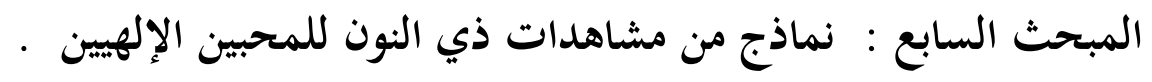

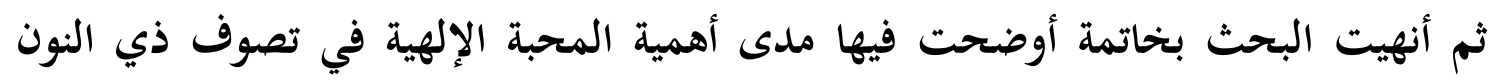

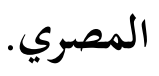




$$
\text { المبحث الاول }
$$

التعريف بذي النون المصري (نشأته وحياته العلمية)

هو أبو الفيض ثوبان بن إبراهيم المصري، المعروف بذي النون، ولد في مدينة أخميم

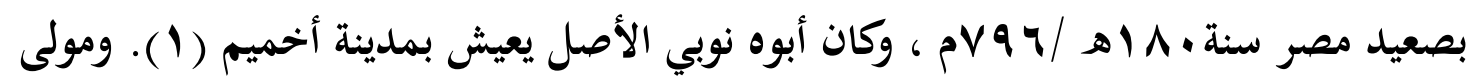

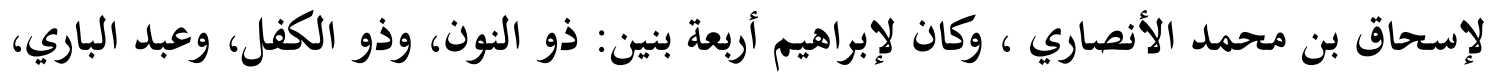

وعبد الخالق (Y) .

نشأ ذو النون في كنف أبيه وأسرته بمدينة أخميم، وتعلم بها حتى بلغ مبلغ الرجال، ووصفه

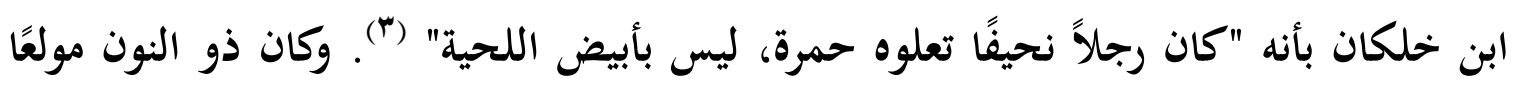

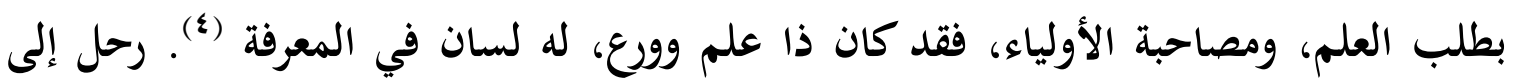
ملدينة الفسطاط، والتقى بالعديد من علمائها ورجالات التصوف بها، وذاع صيته بينهم حتى صار

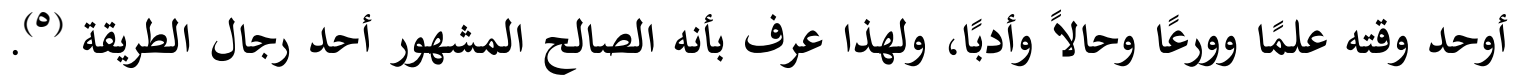
بل أصبح أحد مشاهير الزهاد في وقته بمصر (").

ووصفه المناوي بأنه " العارف الناطق بالحقائق ، الفائق للطرائق ، ذو العبادات الوثيقة والإشارات الدقيقة والصفات الكاملة ، والنفس العاملة والهمم الجلية ، والطريقة المرضية ،

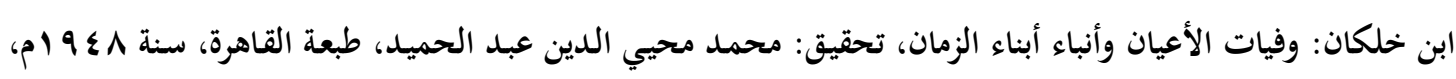

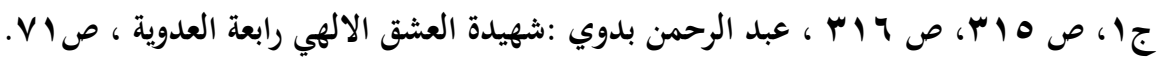

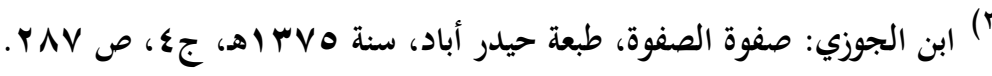

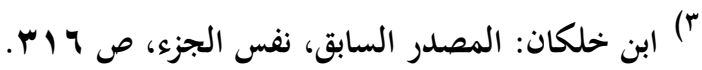

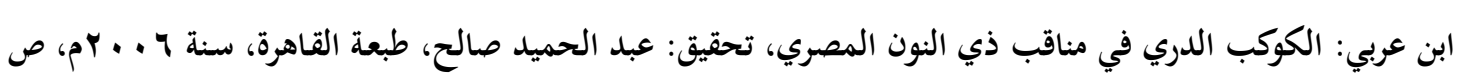

$$
\text { ابن خلكان: المصدر السابق، نفس الجزء، ص ه اس. }
$$

الهجويري: كشف المحجوب، ترجمة وتحقيق: إسعاد عبد الهادي قنديل، مراجعة أمين عبد المجيد، طبعة المجلس

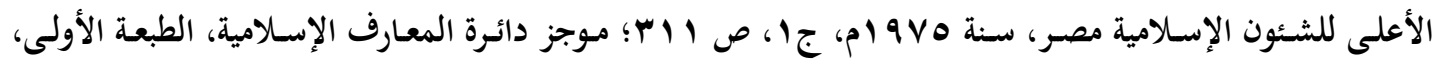

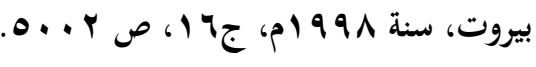


والمحاسن الجزيلة المتبعة ،والأفعال والأقوال التي لا تخشي منها تبعة ، زهت به مصر وديارها،

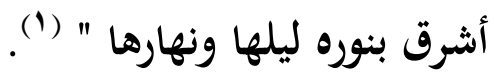

وكان لذي النون طرف كثيرة وكلمات طيبة في حقائق العلوم؛ كقوله: "العارف كل يوم أخشع، لأنه في كل ساعة أقرب" (Г). ودفعه حبه للعلم على تعلم المزيد، فدرس علم الحديث

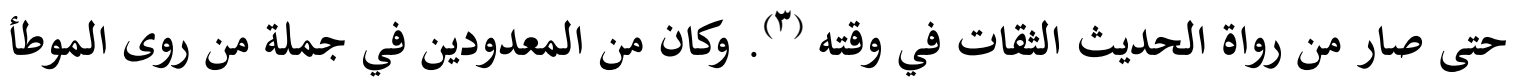
عن الإمام مالك رضي الله عنه (\&). وكان أول من تكلم في ترتيب الأحوال ومقامات أهل الولاية ، وأبرز من أدخل الوجد

$$
\text { والحب المطلق في التصوف (•) }
$$

وقد تحير أهل مصر في شأن ذي النون آنذاك، وأنكروا عليه الكثير من أقواله، وعلى حد قول الهجويري لم يعرف أحد من أهل مصر جمال حاله .." (ه). ولم يسلم من كيد الكائدين

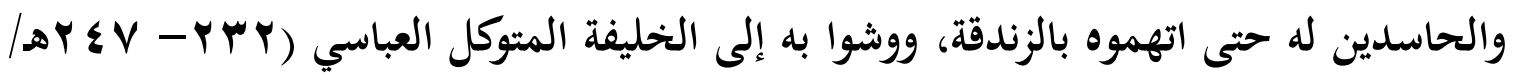

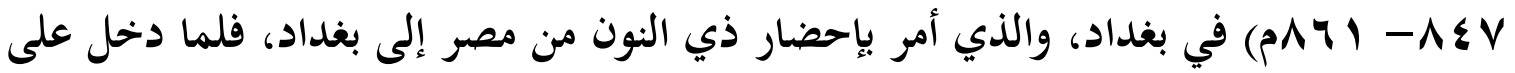
الخليفة المتوكل وعظه ذو النون، فبكى المتوكل ورده مكرمًا إلى مصر، وكان الخليفة المتوكل بعدها إذا ذكر أهل الورع بين يديه يبكي ويقول: "إذا ذكر أهل الورع فحي هلا بذي النون" (V).

$$
\begin{aligned}
& \text { (1) الكواكب الدرية ، حا القسم الثاني ،صوله هـ. }
\end{aligned}
$$

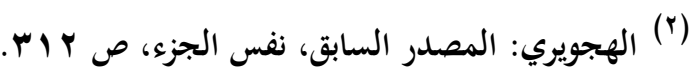

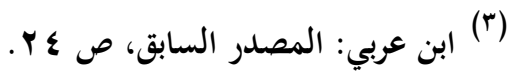

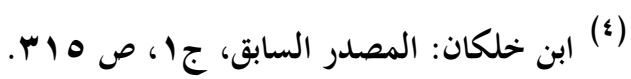

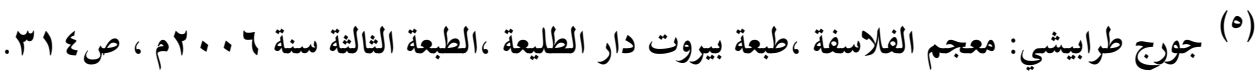

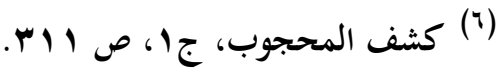

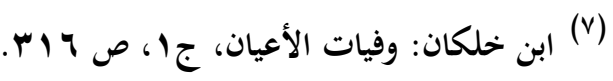


وكثرت رحلات ذي النون وسياحاته في البلدان، وتقابل مع عديد من الأولياء والصالحين

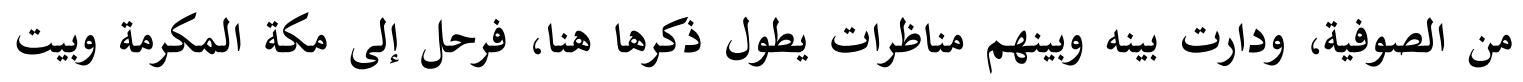

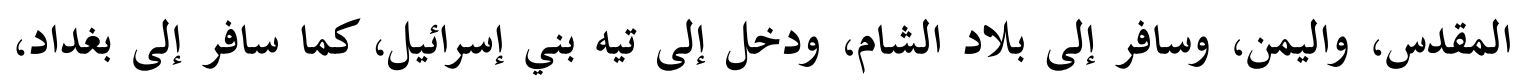

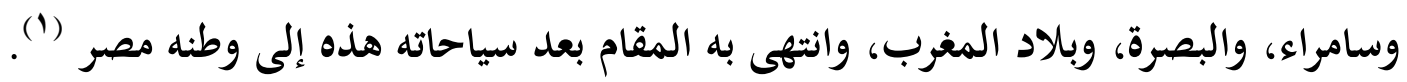

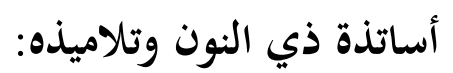

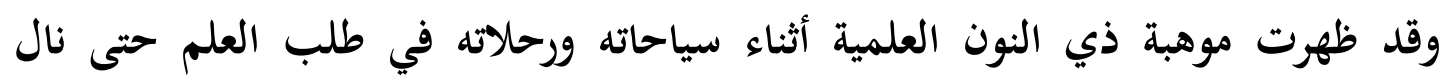

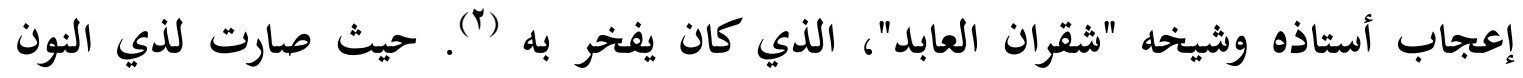

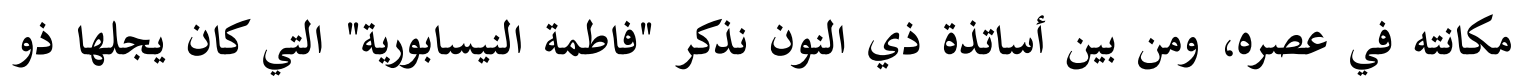

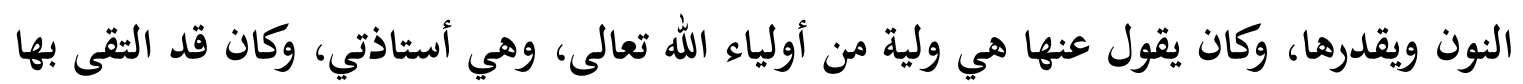

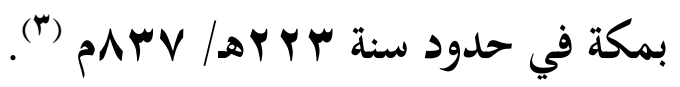

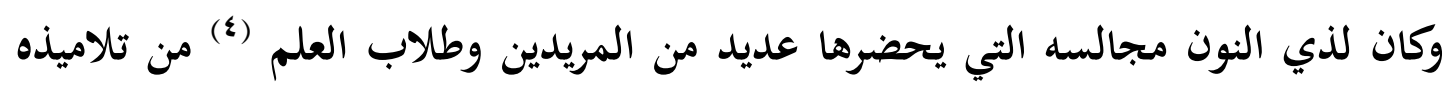

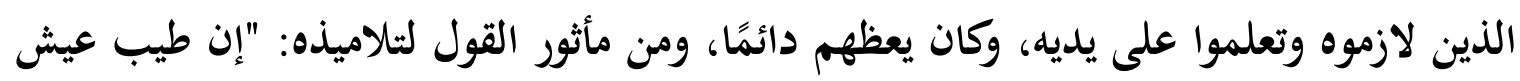

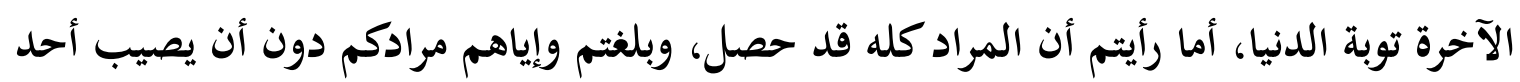

ومن تلاميذ ذي النون نذكر: إسرافيل المغربي، يوسف بن الحسين، أبو عبد الله بن الجلا،

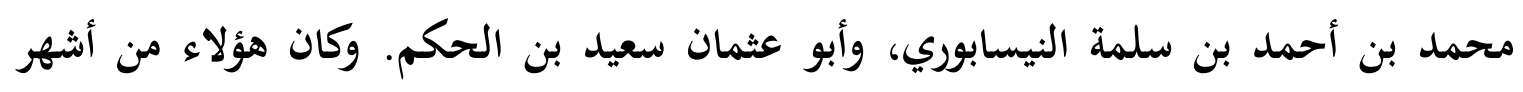

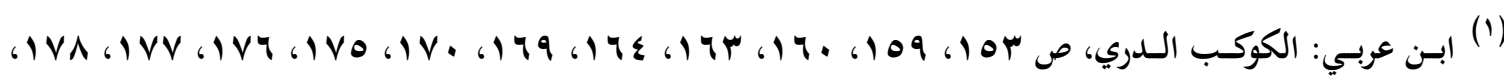

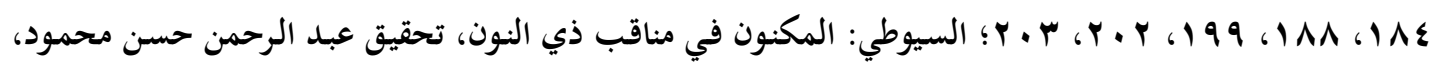

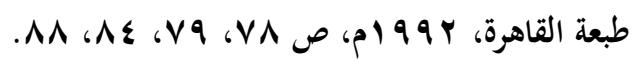

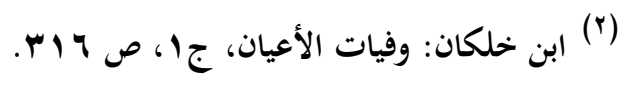

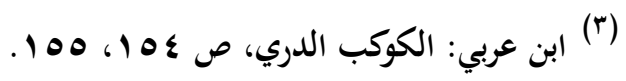

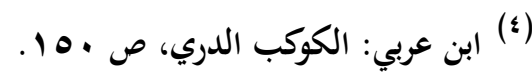

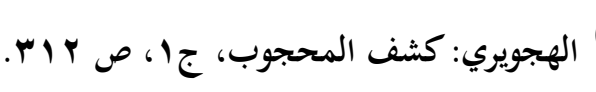


تلاميذ ذي النون المصري، الذين نقلوا عنه الكثير من أقواله، وكانوا ملازمين له في إقامثه بالجيزة من أرض مصر (1). وفي هذه الفترة بلغ ذو النون مبلغًا كبيرًا بين علماء وصوفية عصره، وينسب إليه أنه واضع أسس النصوف(ז). وكان أول من قعد وأصلح مصطلحات الطريق وبين معارفه، وكان له لسان في المعرفة والمحبة، وكلامه معظمه يدور حول الألفة والهوى والوداد والأنس والشوق والذكر والوصال والعشق، ولغته هي لغة القلوب والحب والمحبة والمحبين (Г). كما كان أول من تكلم بمصر في ترتيب الأحوال، وفي مقامات الأولياء (؛).

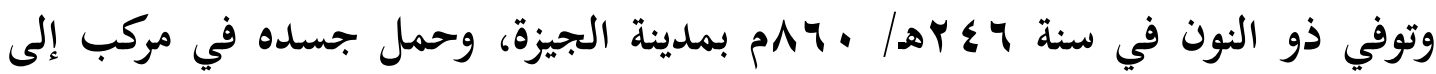
مدينة الفسطاط، خوفًا عليه من زحمة الناس على الجسر، ودفن في مقابر أهل المعافر (ه). ومما يدل على مكانة ذي النون وولايته بين أهل التصوف، ما ذكره الهجويري بأنه في الليلة التي فارق فيها ذو النون الدنيا، رأى سبعين رجلاً النبي عليه السلام في النوم يقول: "إن حبيب الله ذا النون يزمع المجيء، وقد جئت لاستقباله". وحين مات ذو النون ظهر مكتوب على جبينه: "هذا حبيب الله، مات في حب الله، قتيل الله". وذكر أيضًا أنه لما حملوا جنازته، تجمعت طيور السماء، وظللت جنازته، فتحير أهل مصر جميعًا، وندموا على ما كانوا قد ارتكبوه معه من جفاء ، وما فرط منهم في حقه واستغفروا مما انكروه عليه من ولايته

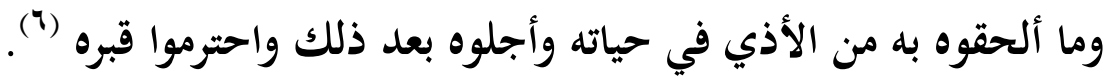

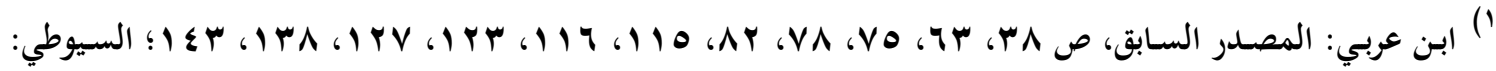

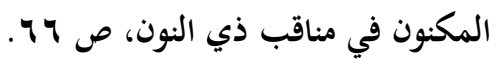

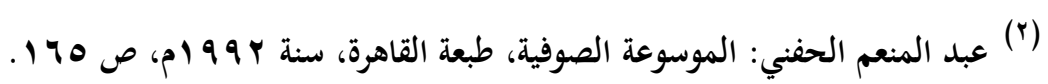

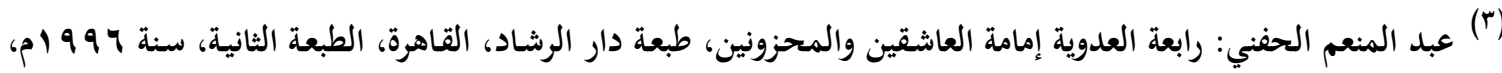

$$
\begin{aligned}
& \text { (๕) السيوطي: المصدر السابق، ص ع } 7 .
\end{aligned}
$$

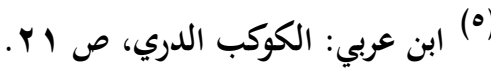

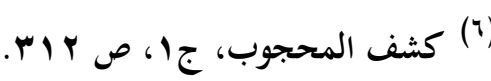




\section{المبحث الثاني}

تعريف المحبة لغةً وفي اصطلاح الصوفية، ودليل المحبة الإلهية

\section{أولاً: المحبة لغةًً: - n}

الحب: نقيض البُغض. والحب: الوداد والمحبة، وأحبه فهو مُحب، وهو محبوب. والحبة

أيضًا: اسم للحب، وتحبب إليه: تودد. والحب: الحبيب، مثل خَدن وخَدين ... الحبيب يجيء

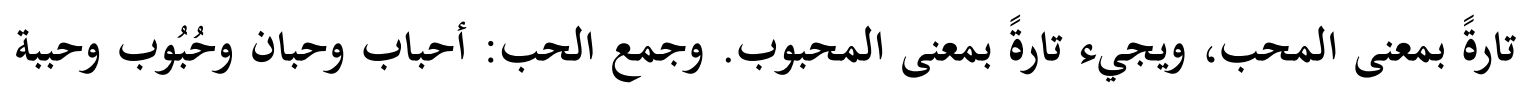

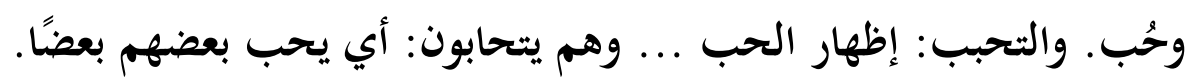
وفي أصل كلمة "حب" و "محبة" اختلف علماء اللغة، فمنهم من قال إن المحبة مشتقة من قولهم: أحب البعير إذا برك فلم يقدر على القيام، فكأن المحب قد لزم قلبه محبوبه فلم يرم عنه انتقالاً، ولم يبلغ عنه حولاً، فالمحب لا يبرح بقلبه عن ذكر المحبوب، بعد أن وقع في المحبة، ولا يقدر على الانفكاك. قال الثاعر:

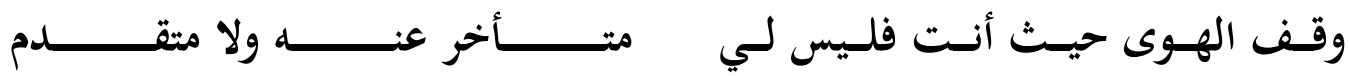

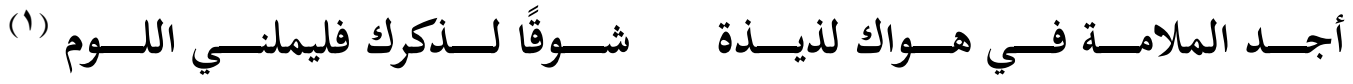

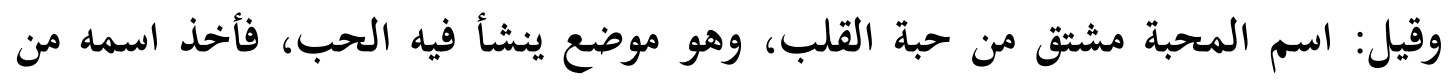
محله، وهو سويداء القلب، ويقال ثمرته، فسميت المحبة بذلك لوصولها إلى حبة القلب، قال الشاعر:

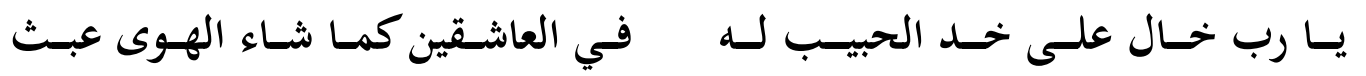

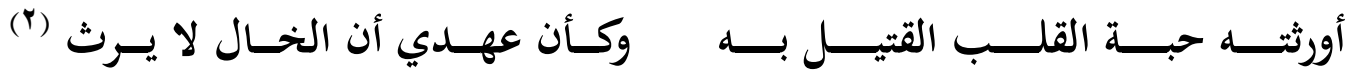

ابن منظور، لسـان العرب، طبعة دار المعارف، جY، مادة (حبب)؛ لسان الدين ابن الخطيب: روضـة التعريف بالحب

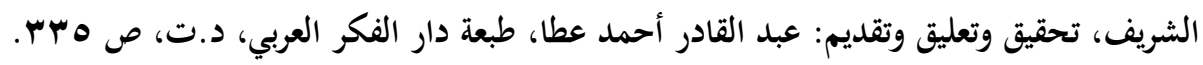

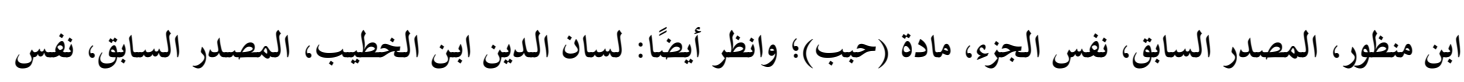


وقيل: الحب مشتق من الحبة، وهو بذر النبات؛ لأن البذور لباب النبات، والحب لباب

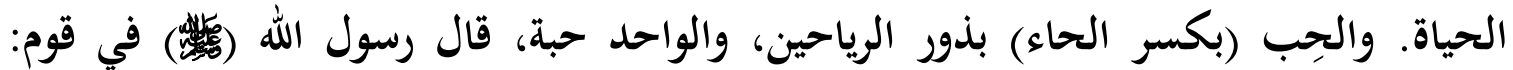

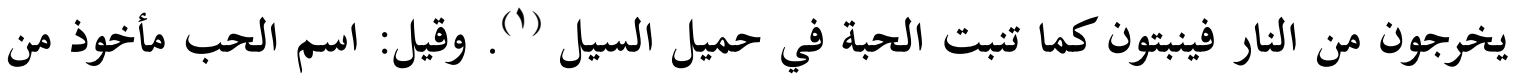

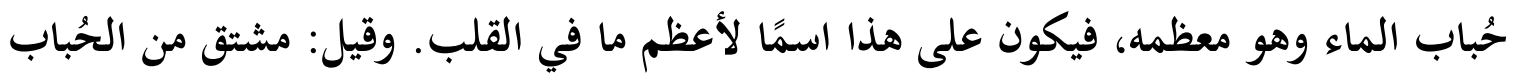

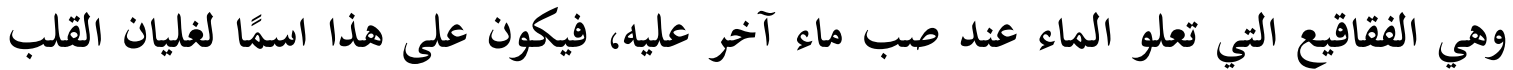
وفورانه عند الشوق والتطلع إلى لقاء المحبوب (ب).

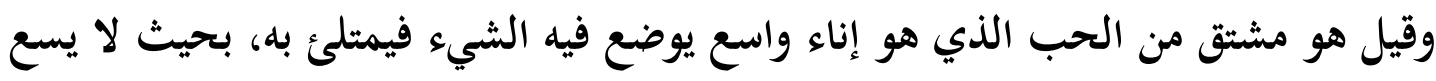
غيره، كذلك قلب المحب ليس فيه سعة لغير محبوبه. وقيل أصله من الحبّ، وهو القرط؛ لأن القرط يهتز ويميل ويضطرب في أذن المرأة المتحلية به، وكذلك المحب قلق يخشى على فيلى حبه وحبيبته فلا يثبت ولا يستقر، قال الشاعر:

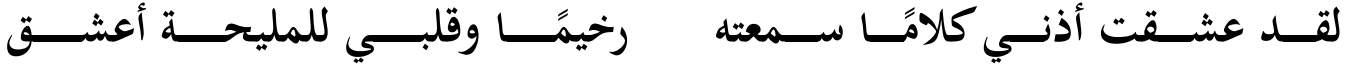

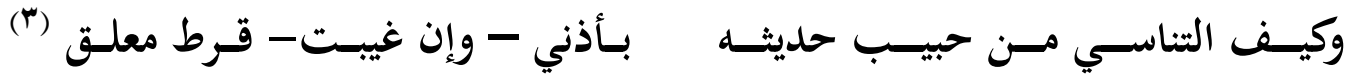
وقيل أصل المحبة الصفاء لأن العرب تقول لصفاء بياض الأسنان ونضارتها حبب الأسنان، وسميت المحبة بذلك لما يستلزم قلب المحب من الصفاء. فكأن محبة المحب هي صفاء

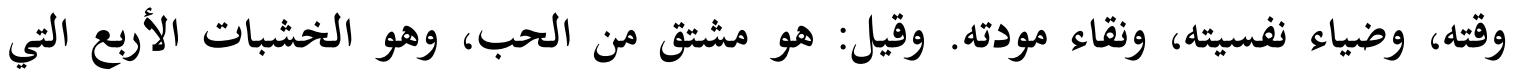
يستقر عليها ما يوضع عليها من جرة أو غيرها، فسمي الحُب بذلك؛ لأن المحب يتحمل لأجل

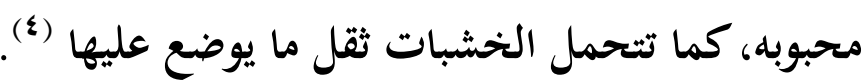
نستخلص مما سبق أن لفظة حب في اللغة العربية تفيد معاني عدة، منها اللزوم والثبات واللب والعلو والظهور، والحفظ والإمساك، والصفاء والبياض، وهذه المعاني على اختلافها تجتمع جميعها في المحب، وتدل على مدى تأثير هذه العاطفة القوية في نفسه.

$$
\text { (1) (1) ابن منظور ، لسان العرب، نفس الجزء، مادة (حبب). }
$$

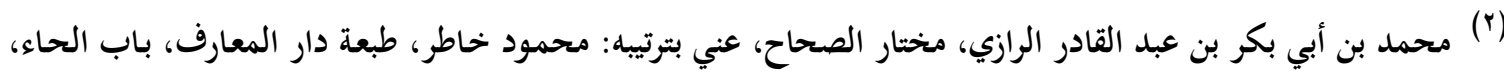

مادة (حبب).

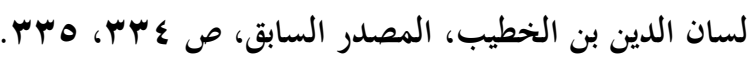

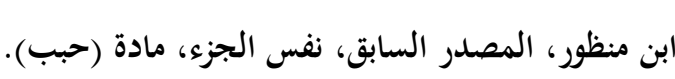




$$
\text { ثانياً : المحبة في اصطلاح الصوفية: }
$$

الحقيقة أن المتصوفة تكلموا جميعًا في المحبة، وأفردوا لها مساحات واسعة من كتاباتهم؟ لأنها الحال أو الصفة التي تفصل بينهم وبين غيرهم الذين تقوم عباداتهم الله على أساس الطمع في الثواب والخوف من العقاب. أما المتصوفة، فحال الطمع في الثواب والخوف من العقاب لا تستقيم عندهم، لأنهم تجردوا من الدنيا وعلائقها، ومن الآخرة وما فيها، وتركز طمعهم في شيء واحد هو لقاء الحبيب (الله) (1).

وهنا نتساءل ما هو تعريف الحب عند الصوفية؟

للإجابة عن هذا التساؤل نجد أنفسنا أمام رأيين مختلفين: أحدهما: يرى أن تعريف الحب بتعريف محدد مستحيل. ومن أصحاب هذا الرأي: الإمام القشيري (ז) في قوله: "ولا توصف المحبة بوصف، ولا تحد بحد أوضح ولا أقب إلى الى الفهم من المحبة ... وعبارات الناس عن المحبة كثيرة" ("َ). ويقول ابن الخطيب (\&): "ولما كانت الحدود تأتلف من مقومات التهات الشيء وأجزائه الذهائه الذاتية،

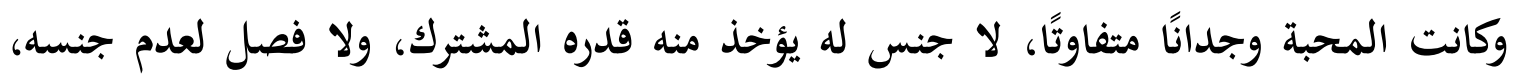

(1) عبد القادر عيسى: حقائق عن النصوف، ط. مطابع الديوان، نورويش، إنجلترا، د.ت، ص YV r.

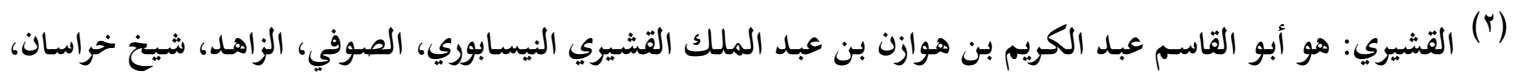

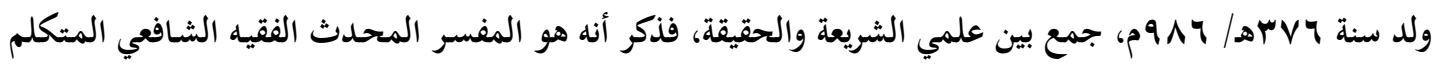

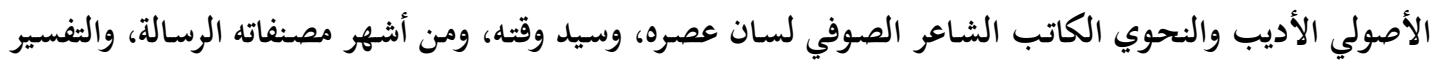

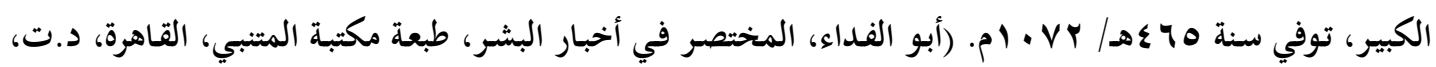

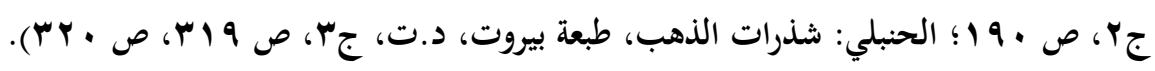

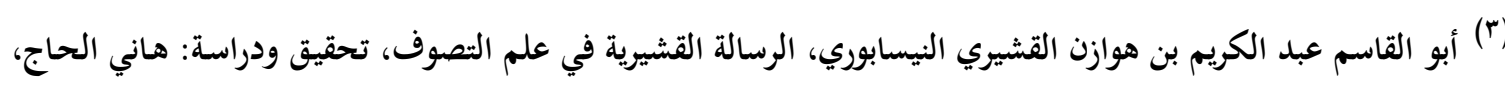

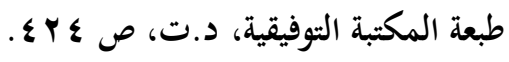

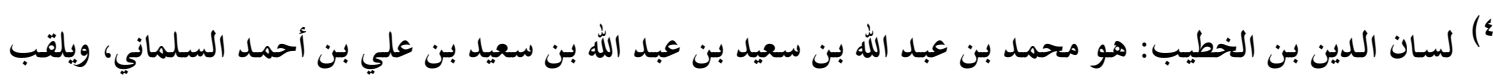

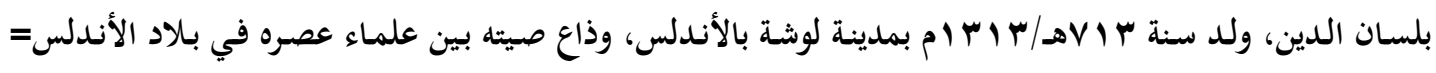


تعذر هذا المطلوب مع مسامحة كبيرة فيه، فغالب ما نقل عن المتقدمين من رسوم وتعريفات،

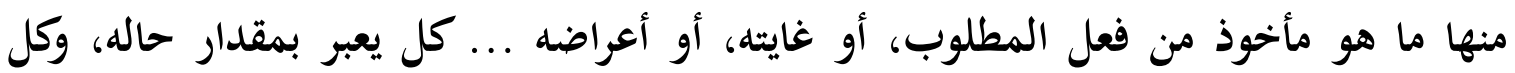

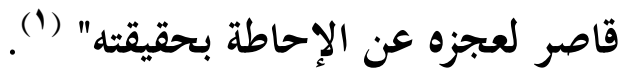

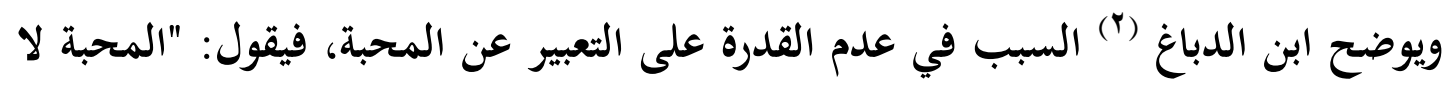

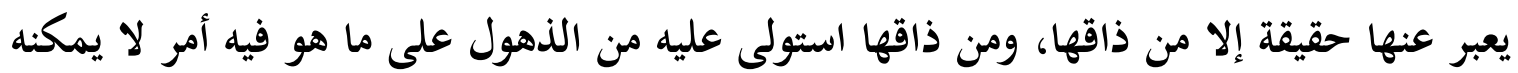

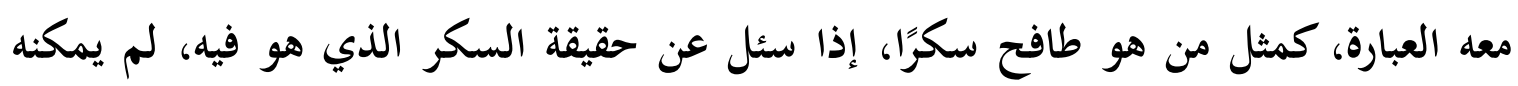

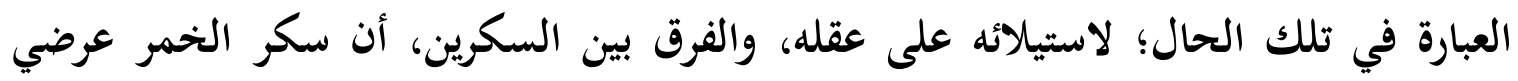

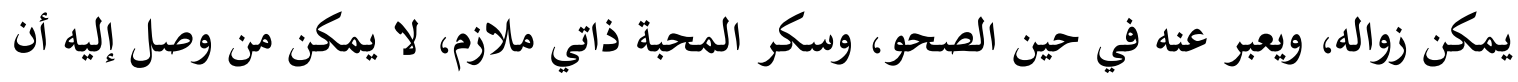
يصحو منه حتى يخبر فيه عن الحقيقة" (").

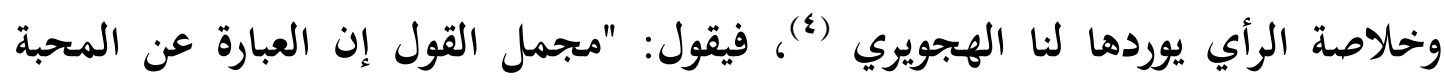

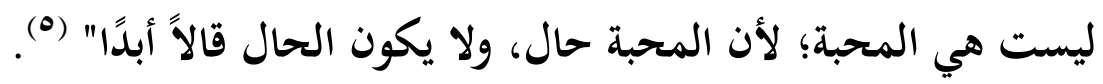

=

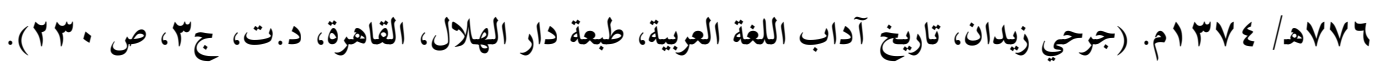

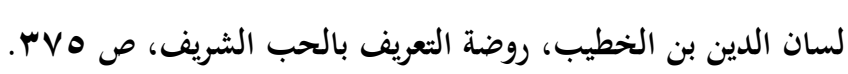

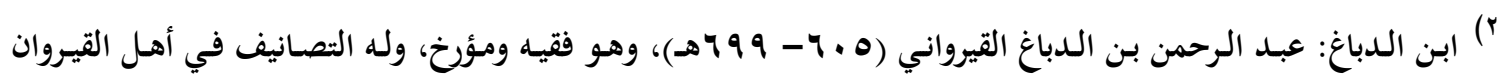

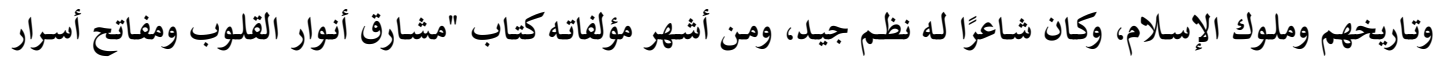

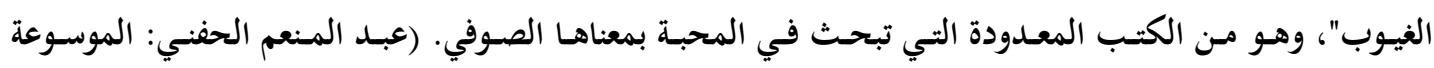

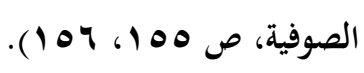

عبد الرحمن بن محمد الأنصاري المعروف بـ (ابن الدباغ): مشارق أنوار القلوب ومفاتح أسرار الغيوب، تحقيق هـ ريتر،

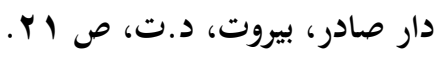

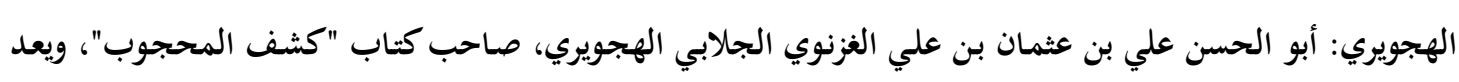

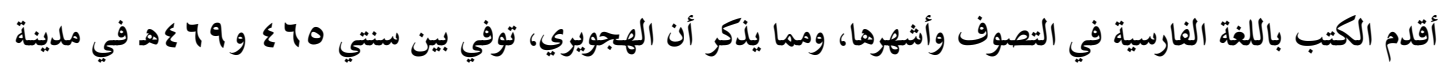

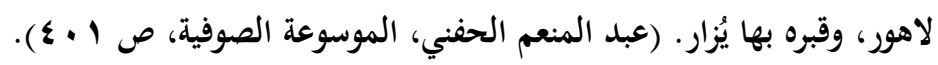

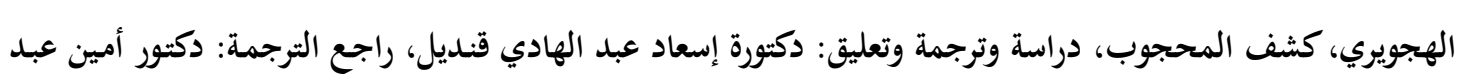

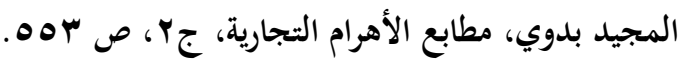


وأما الرأي الثاني: فيقرر إمكان الوصول إلى تعريف محدد لمعنى الحب، وغاية ما هنالك أن هذا التعريف ليس من قبيل التعريفات العلمية التي تكون موضع الاتفاق، وإنما لا بد فيه من وقوع الاختلاف بين تعريفات الحب تبعًا لاختلاف طبيعة الإحساس بله، وتفاوت القدرة على التعبير عنه عند الصوفية، وقد أدى ذلك إلى كثرة التعريفات وتعددها واختلافها، وإن كان الاختلاف غالبًا اختلافًا في الألفاظ لا في المعنى. ومن هذه التعريفات على سبيل المثال: يعرف المحاسبي (1) المحبة فيقول: "ميلك إلى الى لهيل الشيء بكليتك، ثم إيثارك له على نفسك وروحك ومالك، ثم مرافقتك له سرًا وجهرًا، ثم علمك بتقصيرك في حبه" (r) ويعرفها الجنيد(") بقوله: "المحبة ميل القلوب". ويشرح الكلاباذي هذا فيقول: معناه أن يميل قلبه إلى الله وإلى ما الله من غير تكلف.

(1) أبو عبد الله الحارث بن أسد المحاسبي: كان شيخ مشايخ بغداد في وقته، كان عالئًا بالأصول والفروع، واقتدى بهل

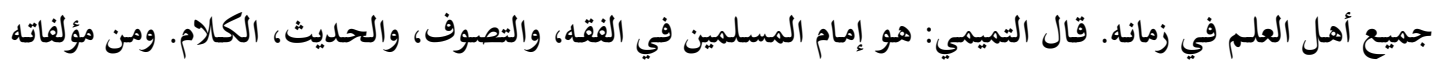

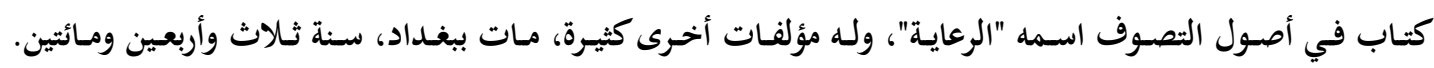

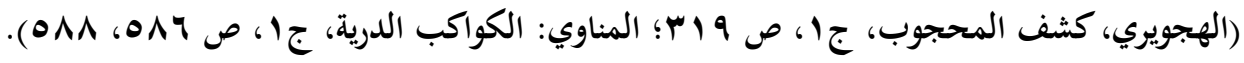

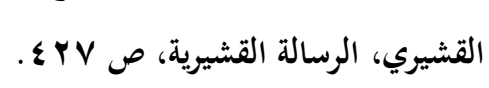

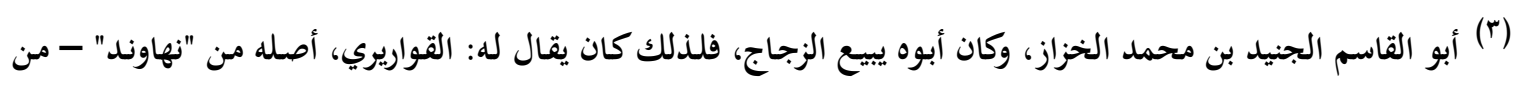

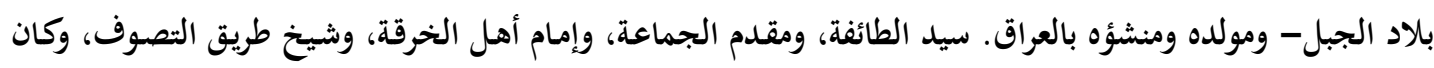

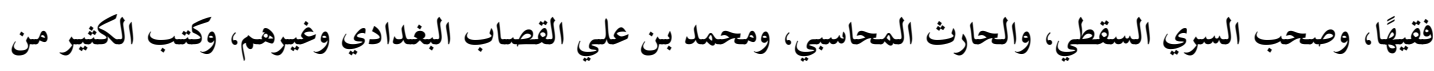

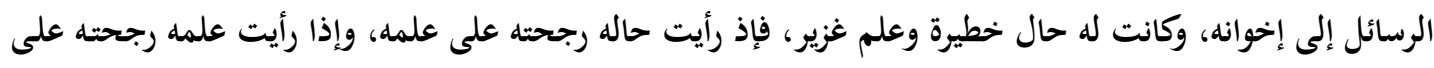

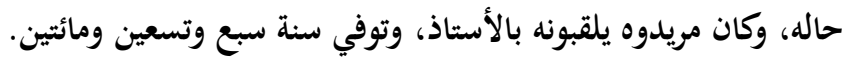

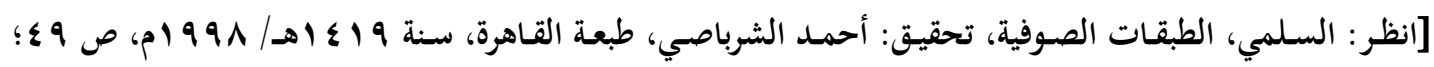

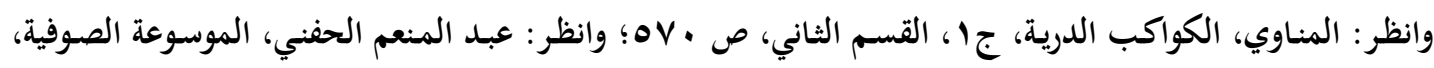

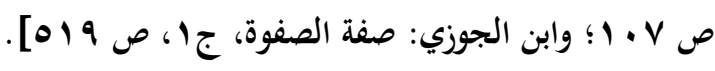


وقال غيره: المحبة هي الموافقة، معناه: الطاعة له فيما أمر، والانتهاء عما زجر، والرضا بما

حكم وقدر (1) حيرن)

وعرفها آخرون فقالوا: المحبة الميل الدائم بالقلب الهائم.

وقيل: المحبة إيثار المحبوب على جميع المصحوب.

وقيل: موافقة الحبيب في المشهد والمغيب.

وقيل: محو المحب لصفاته وإثبات المحبوب بذاته (ז).

وإذا كان الوصول إلى تعريف دقيق للمحبة أمرًا صعبًا كما يرى بعض الصوفية؛ لذلك فإن بعض المتصوفة تحدثوا عن حقيقة الحب حديثًا لا يتقيد بحدود التعريفات الموجزة، فكان

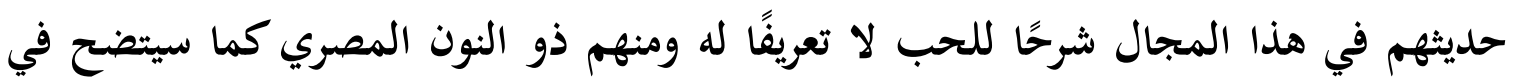

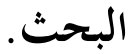

فقد قالت رابعة العدوية (") عندما سألت عن حقيقة إيمانها: "ما عبدته خوفًا من ناره، ولا

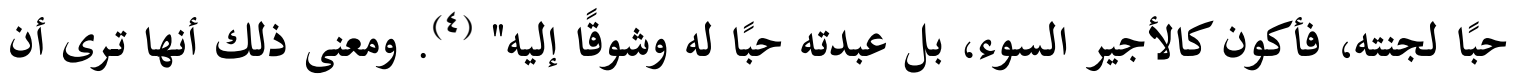
الحب لا بد أن يكون مجردًا عن المطامع والشهوات، وأن يكون المحب مخلصًا في حبه لله

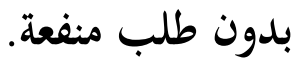

(1) أبو بكر محمد الكلاباذي، التعرف لمذهب أهل التصوف، قدم له وحققه وراجع أصوله وعلق عليه: محمود أمين

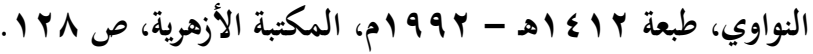

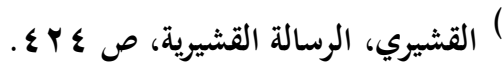

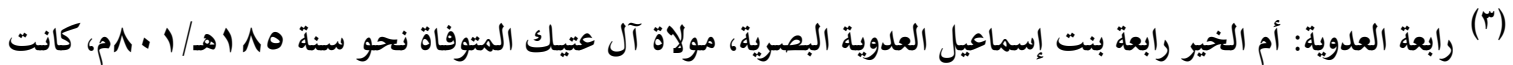

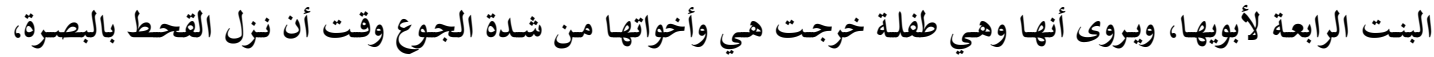

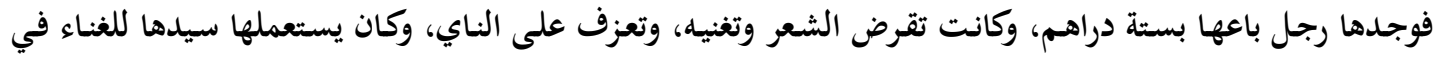
مجالسه، وكان ذلك يسخطها عليه بسبب اتجاهاتها الدينية القوية حتى أعتقها. وانصرفت بكليتها إلى العبادة والتقرب التهاب التهاب

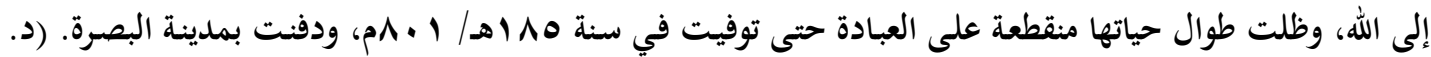

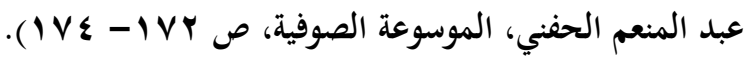

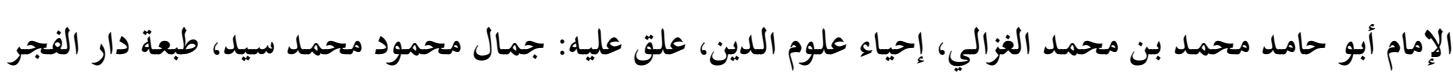


أما الكرخي (1)، فلم يبعد كثيرًا في مفهومه للمحبة عن رأي رابعة، فقد أجاب عندما سأله

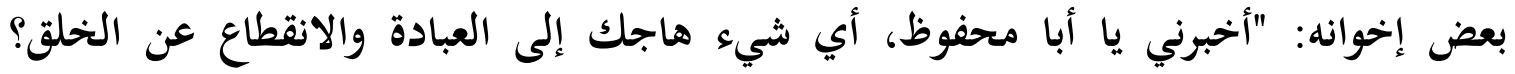

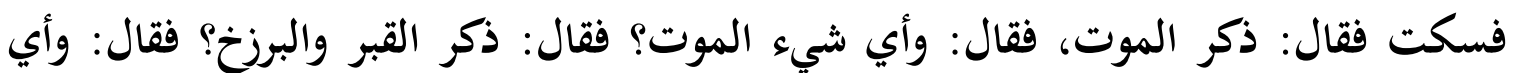

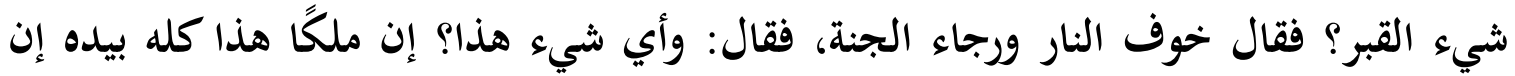

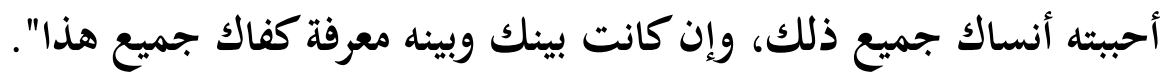

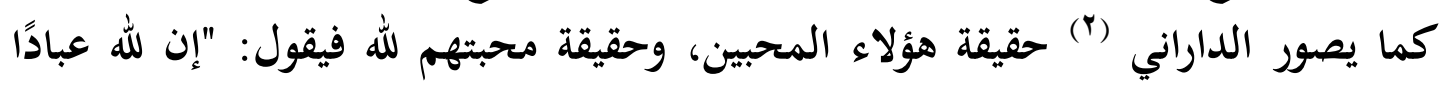
ليس يشغلهم عن الله خوف النار، ولا رجاء الجنة، فكيف تشغلهم الدنيا عن الله؟!" (ب).

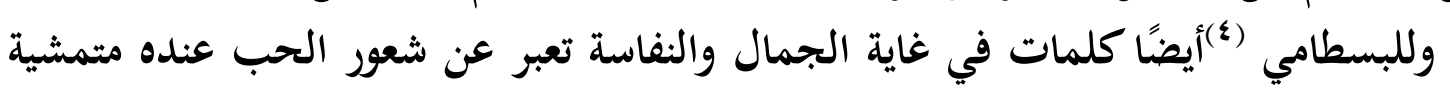

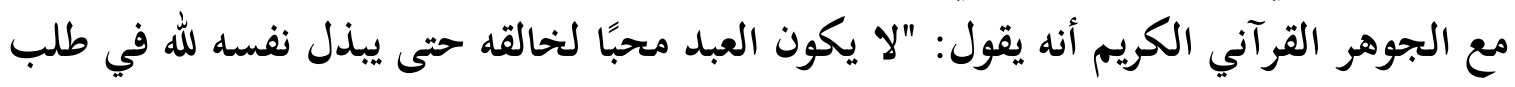

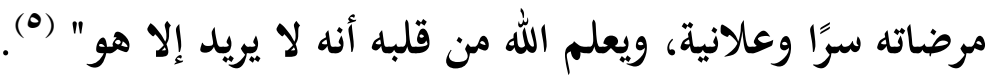

(1) أبو محفوظ معروف بن فيروز الكرخي. ويقال معروف بن الفيرزان. ويقال: معروف بن علي، وهو منسوب إلى كرخ

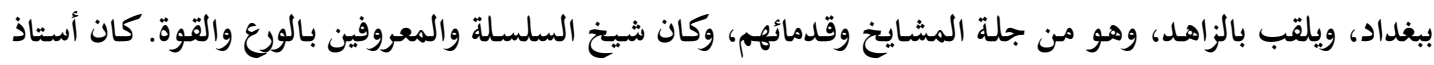

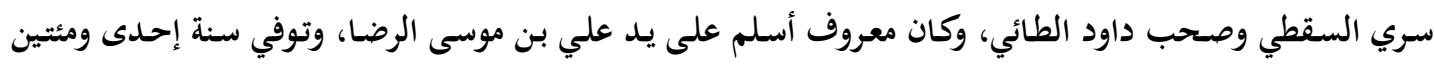

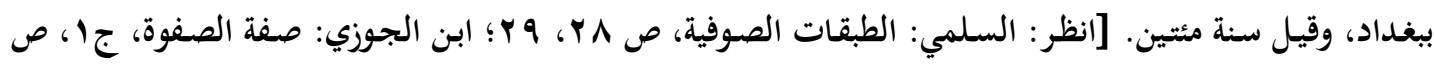
[ [

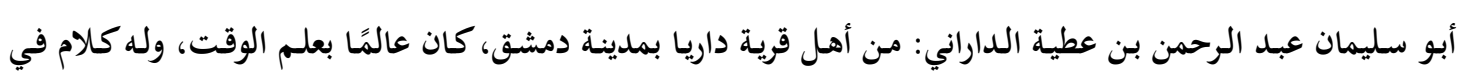

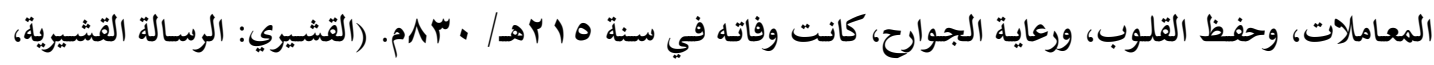

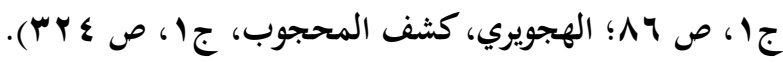

$$
\begin{aligned}
& \text { أبو حامد الغزالي، المصدر السابق، نفس الجزء والصفحة. }
\end{aligned}
$$

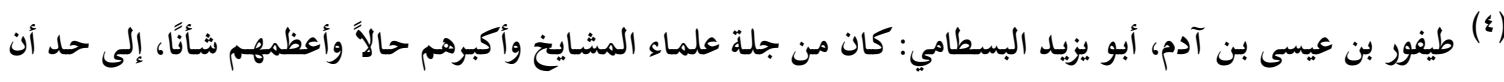

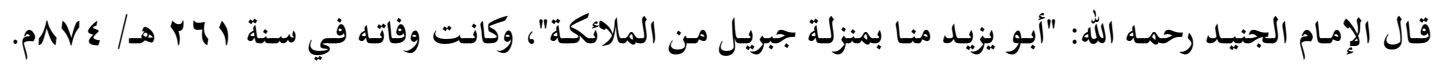

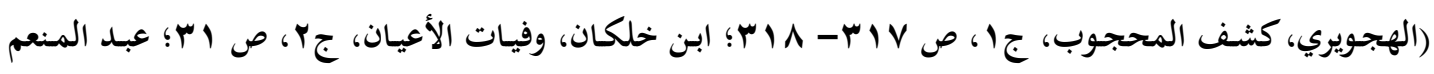

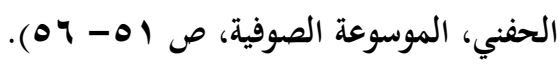

(•) عبد الحليم محمود، سلطان العارفين أبو يزيد البسطامي، طبعة القاهرة، د.ت، ص سب آ أ. 


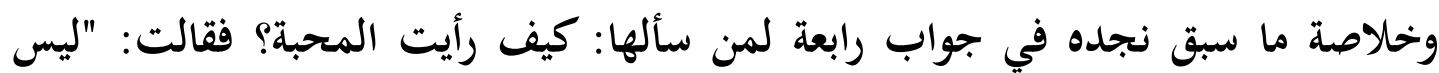

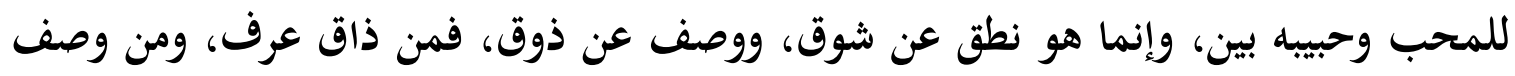

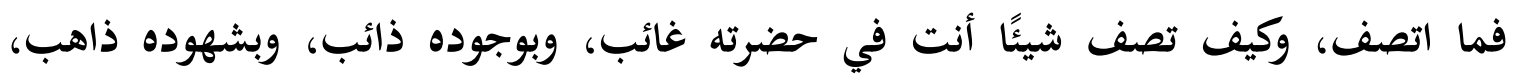

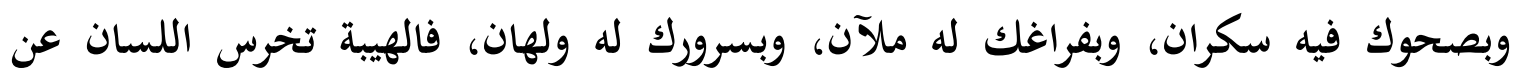

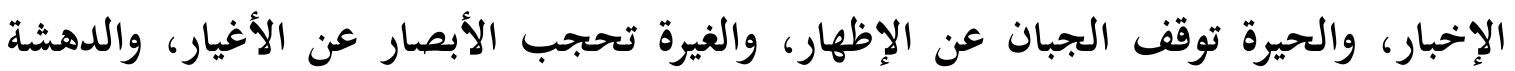

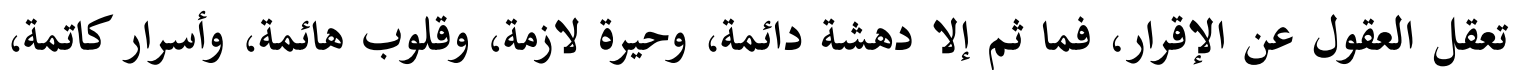

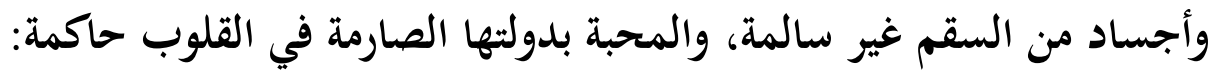

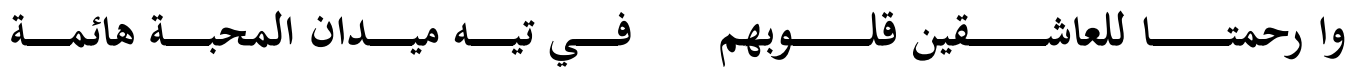

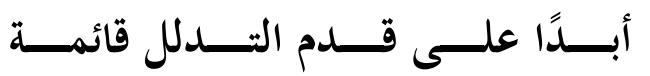

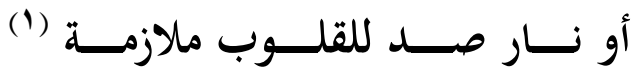

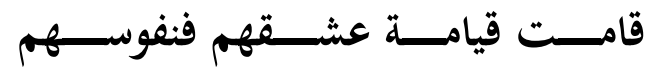

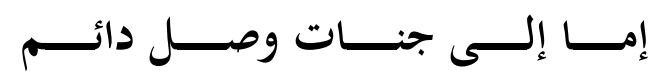

ثالثاً : دليل المحبة الإلهية : ارتبط مفهوم الحب الإلهي في تاريخ الفكر العربي الاسلامي بالصوفية ، والواقع أن مفهوم

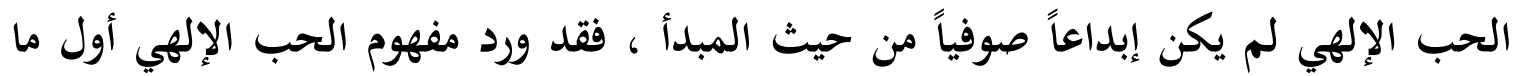

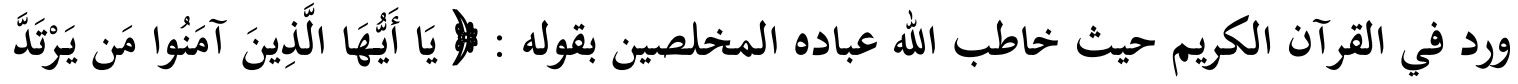

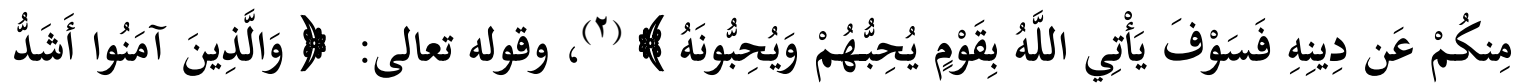

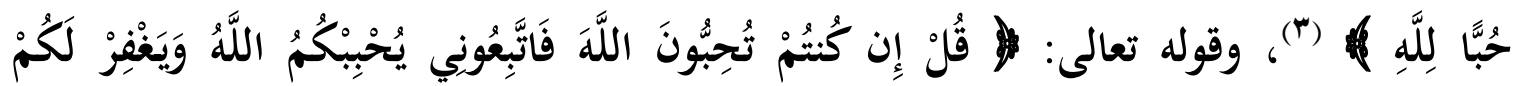

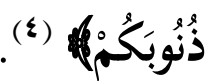

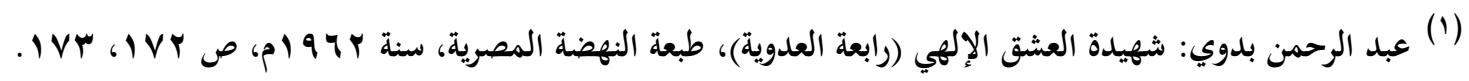

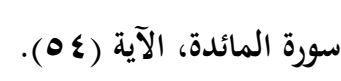

سورة البقرة، الآية (170). النظر: أبو حامد الغزالي: إحهاء علوم الدين، ج؛، ص به بـ.

$$
\text { سورة آل عمران، الآية (ال). }
$$


وقد ورد العديد من الآيات في القرآن الكريم تؤكد حب الله للمؤمنين، بحيث يشمل هذا

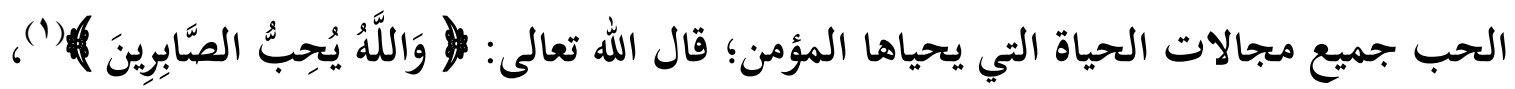

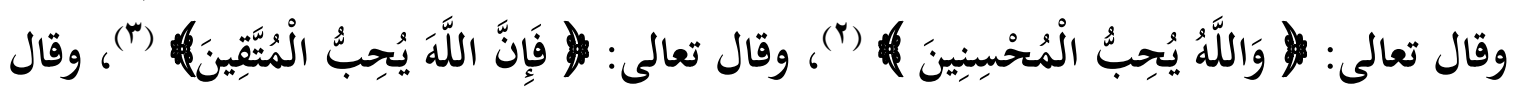

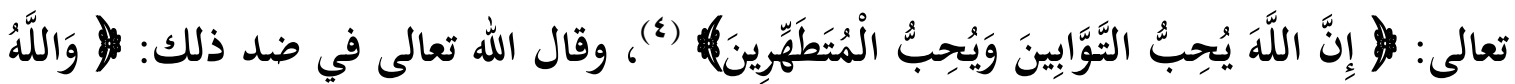

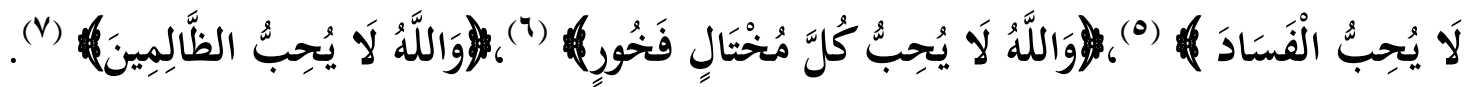
وفي السنة النبوية أيضًا كثرت الأحاديث وتعددت في الدلالة على المحبة الإلهية؛ فعن

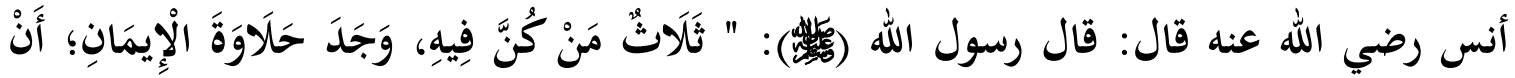

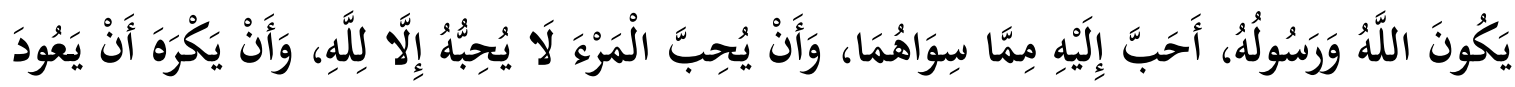

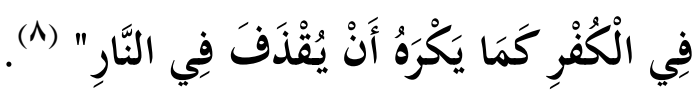

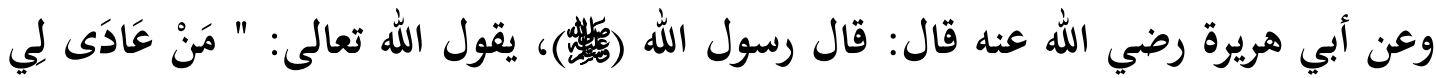

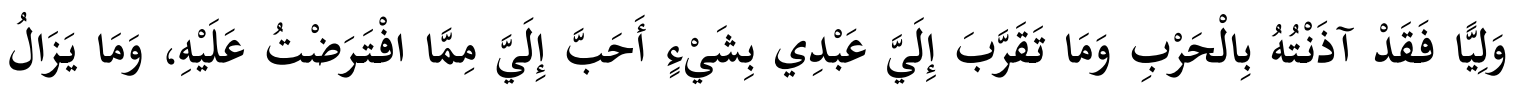

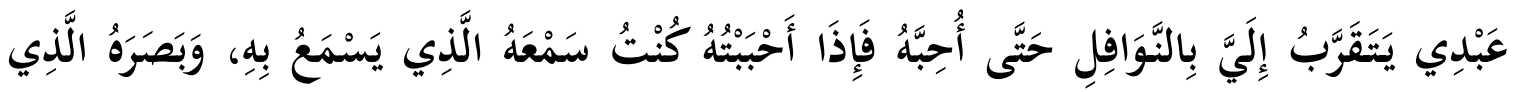

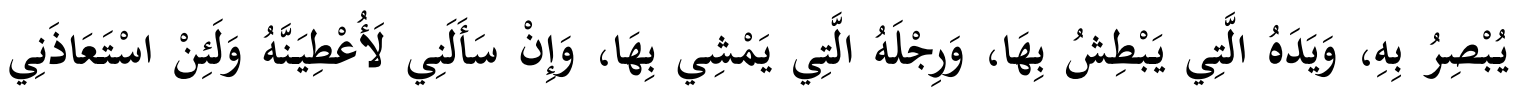

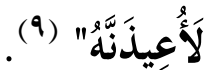

$$
\begin{aligned}
& \text { سورة آل عمران، الآية († ( ) (1). } \\
& \text { سورة المائدة، الآية (به). } \\
& \text { سورة آل عمران، الآية (VY). }
\end{aligned}
$$

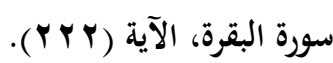

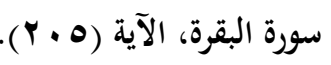

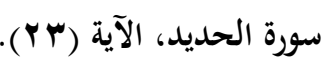

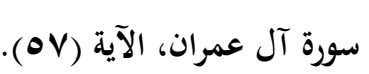

$$
\begin{aligned}
& \text { أخرجه البخاري في صحيحه في كتاب الإيمان. } \\
& \text { أخرجه البخاري في صحيحه في كتاب الرقاق، باب التواضع. }
\end{aligned}
$$




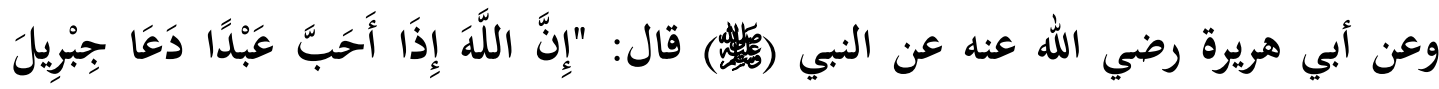

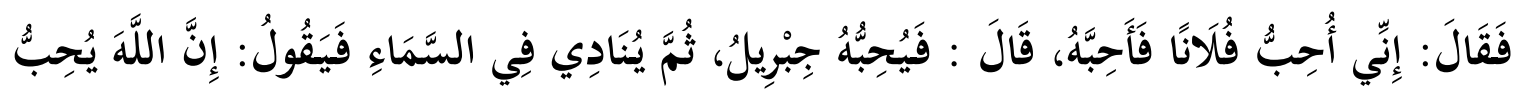

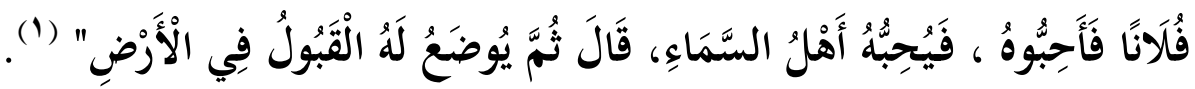

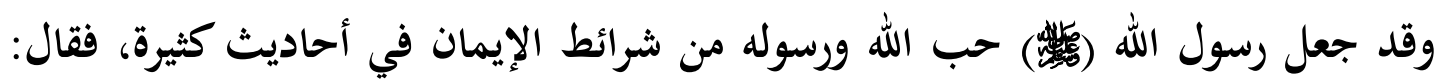

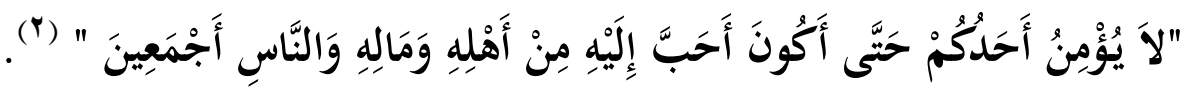

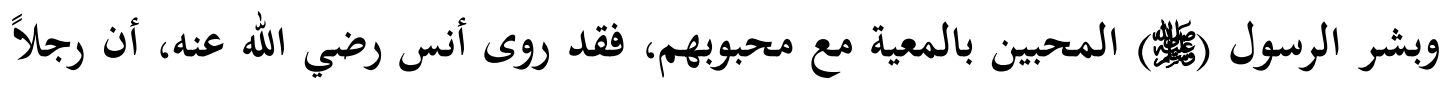

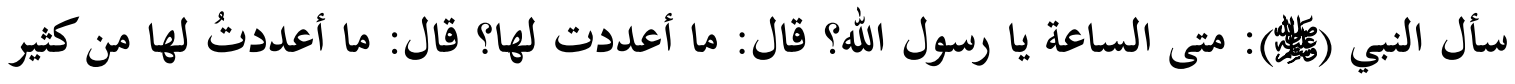

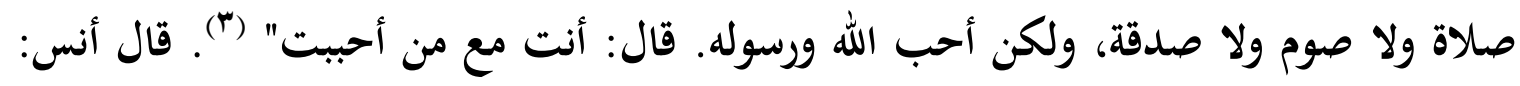
فقلت: ونحن كذلك؟ قال: "نعم"، ففرحنا بها فرحًا شديدًا.

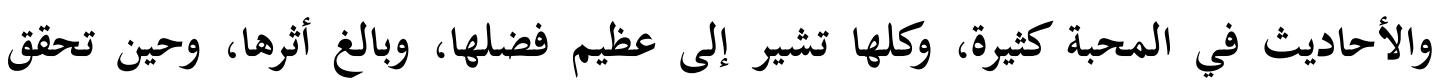

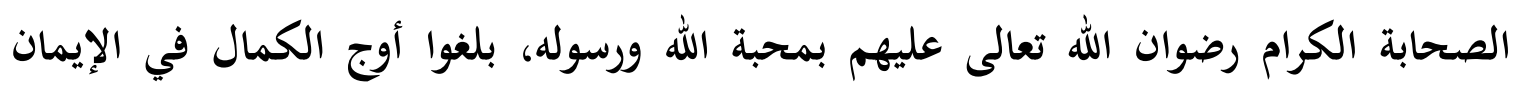

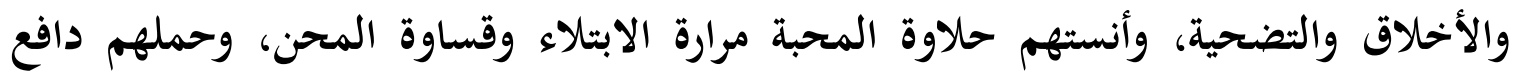

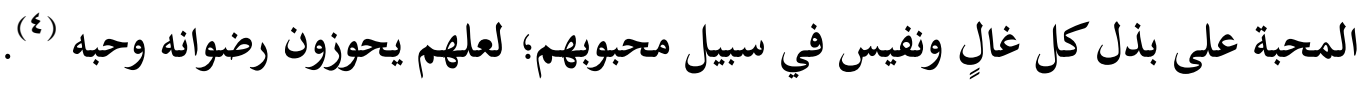

أخرجه البخاري في صحيحه في كتاب بدء الخلق، باب ذكر الملائكة.

رواه البخاري ومسلم في صحيحيهما في كتاب الإيمان عن أنس رضي الله عنه.

رواه البخاري في صحيحه في كتاب المناقب، ومسلم في صحيحه في كتاب البر عن أنس رضي الله عنه.

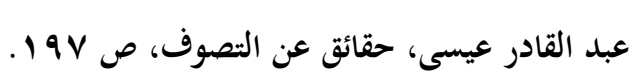




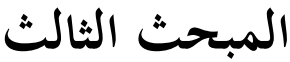

\section{المحبة الإلهية عند ذي النون وعلاماتها}

$$
\text { ا 1-المحبة الإلهية عند ذي النون : }
$$

لقد أرسى ذو النون منذ وقت مبكر في تاريخ التصوف دعائم نظيته في المحبة الإلهية،

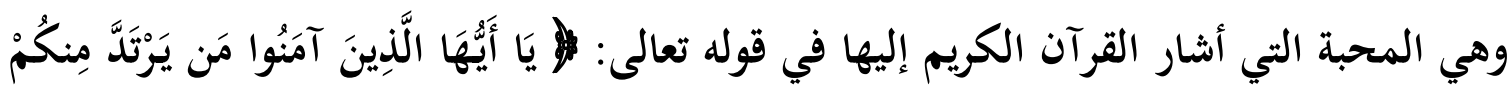

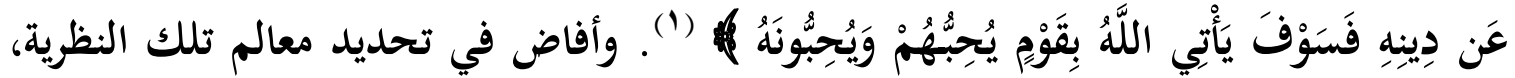
فقد كان كلامه أغلبه في المحبة، وشعره ينصرف في معظمه إلى المحبة وأشواقها ولواعجها؛ وقد تحدث ذو النون عن المحبة من جانب العبد لله بحديث جديد لم يعرف به الناس من قبل، فالذين يحبون الله ترد قلوبهم بحرًا معينًا سماه "بحر محبة الله" (ז)، فيشربون من هذا مدا البحر فيرتوون منه، حينئذ يسهل على هذه القلوب مقاومة أي عارض يعرض لها وهي في سفرها إلى سلى

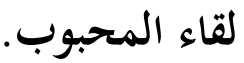

ويذكر ذو النون أن المحبة كما تكون من جانب العبد لله تكون أيضًا من جانب الله للعبد

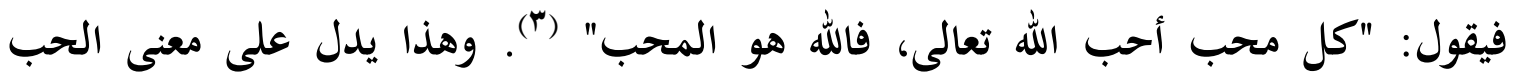
المتبادل بين العبد المحب والرب المحبوب.

والحقيقة أن ذا النون يصطنع لفظتي الحب والمحبة اصطناعًا صريحًا، سواء في تعبيره عن إقبال الله على العبد، أو إقبال العبد على الله، وأنه باستعماله لفظة الحب بنوع خاص إنما يشارك رابعة العدوية التي عاصرته، والتي تعد أول من استعمل هذه اللفظة استعمالاً صريحًا فيما

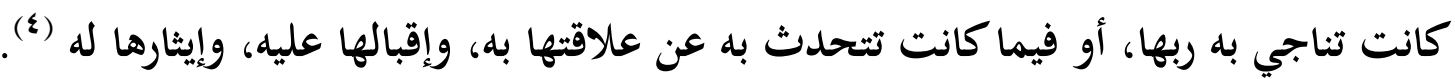

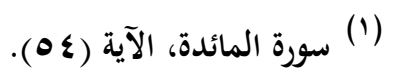

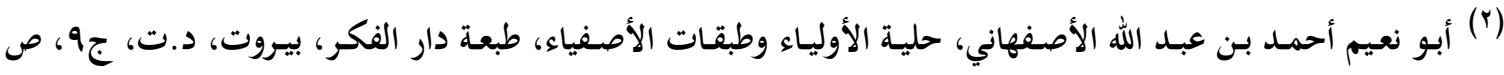

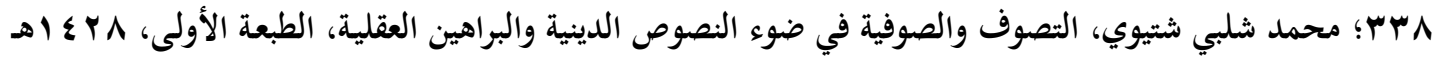

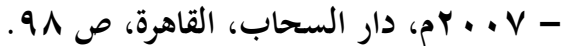

$$
\begin{aligned}
& \text { () محيي الدين بن عربي: الكوكب الدري في مناقب ذي النون المصري، ص • . . }
\end{aligned}
$$

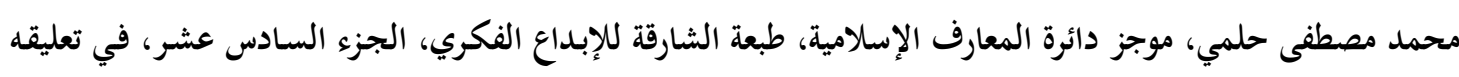

$$
\text { على مادة ذي النون. }
$$


ولغة ذي النون في المحبة الإلهية لغة العارف، والفرق بينه وبين رابعة في مجال المحبة أن

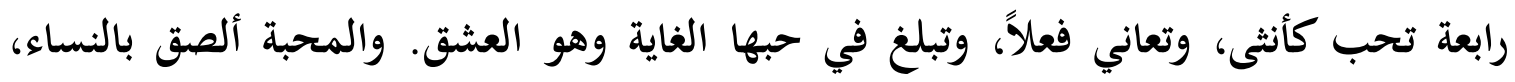

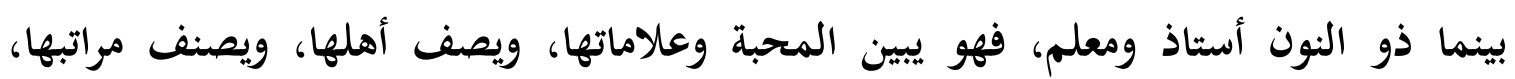

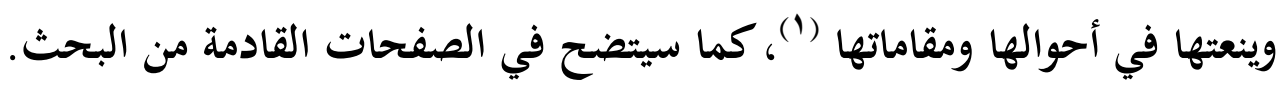

وأما أسلوبه في المحبة فهو أسلوب قوي متأجج العاطفة، لا هو بالأسلوب الهادئ

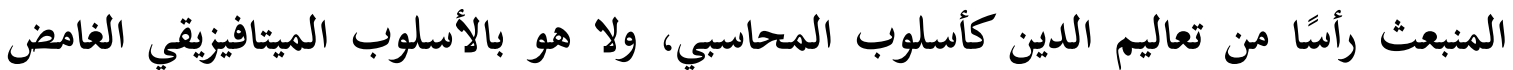

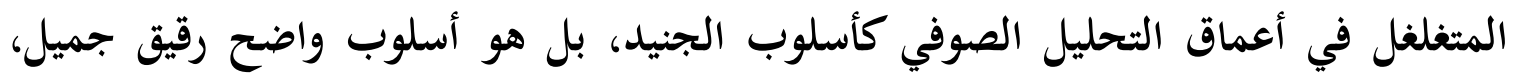

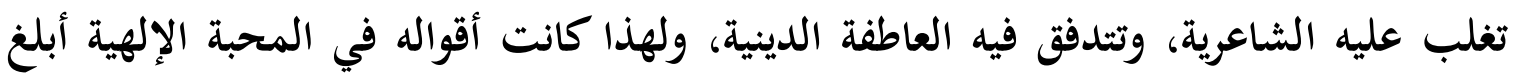
أثرًا في أوساط الصوفية من أقوال غيره(ب).

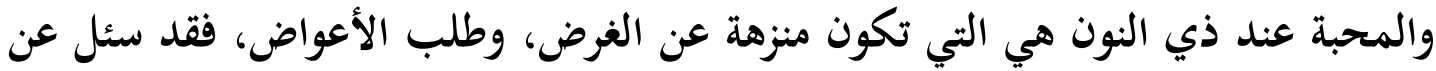
المحبة فقال: هي التي لا تزيدها منفعة، ولا تنقصها مضرة، ثم أنشأ يقول:

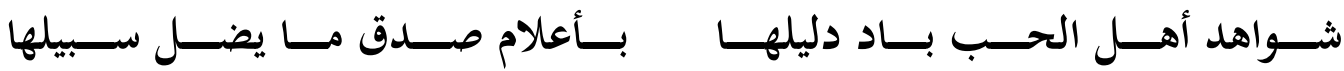

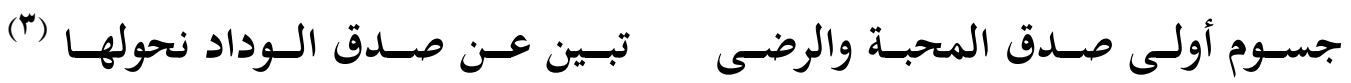

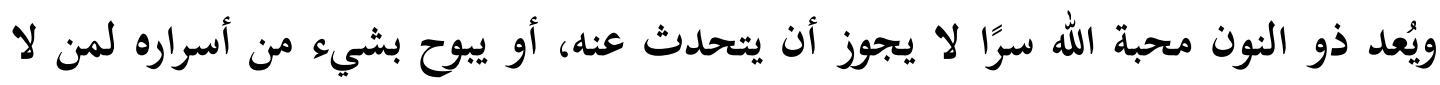
يعرفون من الحب غير معناه المادي الحسي؛ قال وقد تذاكر القوم المحبة في مجلسه: كفوا عن هذه المسألة؛ لئلا تسمعها النفوس فتدعيها، ثم أنشأ يقول:

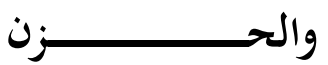

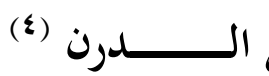
إذ تأل

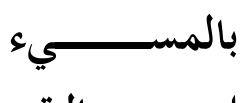

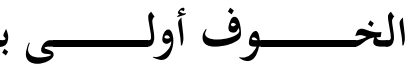

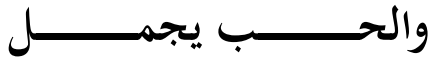

(1) عبد المنعم الحفني، رابعة العدوية إمامة العاشقين والمحزونين، ص به 19.

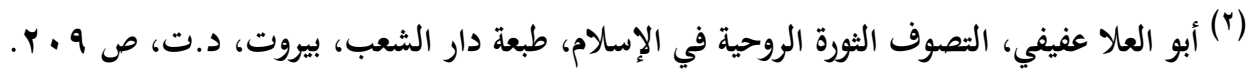

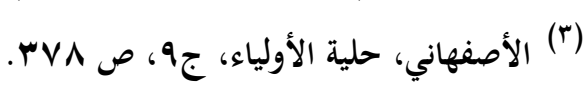

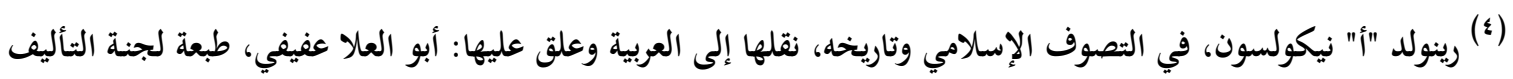

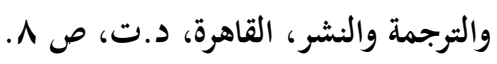


وهذا الموقف هو موقف المقدس للمحبة، الذي يصل تقديسه لها إلى السمو بها، حتى

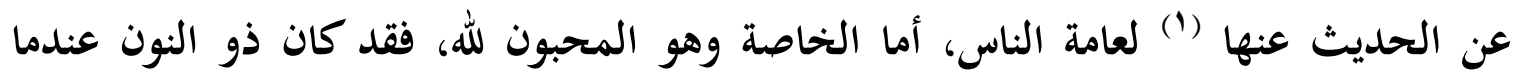
يتكلم في الحب يموج مجلسه بالصارخين والباكين منهم (َ).

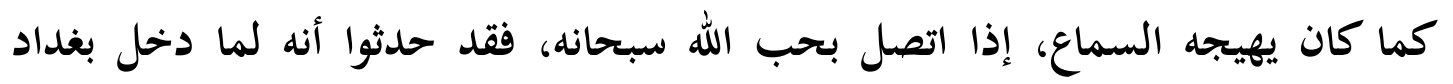
اجتمع إليه الصوفية ومعهم قوال منشد، فابتدأ ينشد:

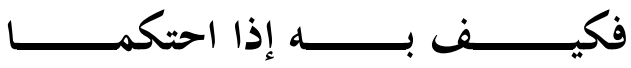

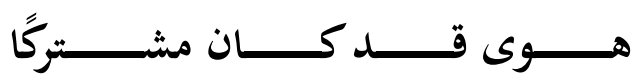

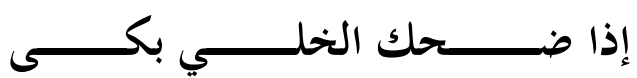

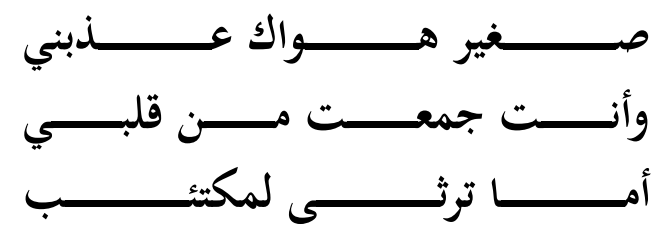

فانتشى ذو النون، ومن شدة نشوته سقط على وجهه، وظل الدم يقطر منه، وهو لا

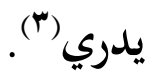
والغاية القصوى للحب الإلهي عند ذي النون، إنما هي حب الله لذاته، والإقبال عليه ابتغاءً لوجهه، دون أن يكون له من وراء ذلك أي مطمع آخر، كما يدل على هذا كله قوله في هذه الأبيات:

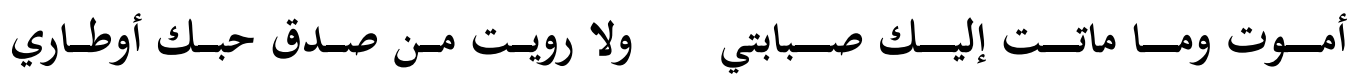

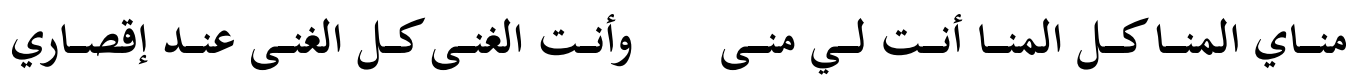

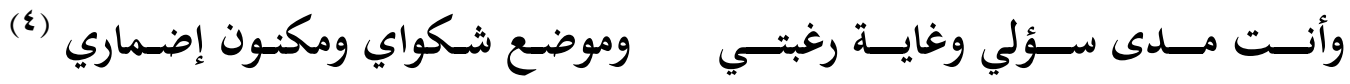

$$
\begin{aligned}
& \text { (1) عبد الحليم محمود، العالم العابد العارف بالله ذو النون المصري، طبعة دار الرشاد، القاهرة، سنة ع . . Y م، ص } 9 \text { ـ. }
\end{aligned}
$$

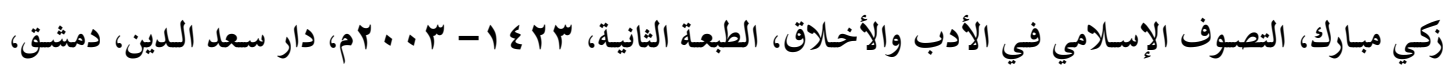

$$
\begin{aligned}
& \text { ج } \\
& \text { عبد الحليم محمود، ذو النون المصري، ص } 19 .
\end{aligned}
$$

محمد مصطفى حلمي، موجز دائرة المعارف الإسلامية، في تعليقه على مادة ذي النون؛ وانظر: أبو الفرج ابن الجوزي:

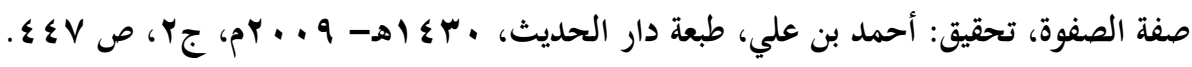




\section{r-علامات المحبة الإلهية عند ذي النون:}

يدعي كثير من الناس محبة الله عز وجل، وما أسهل دعوى اللسان، فلا ينبغي للإنسان أن يغتر بخداع النفس، بل عليه أن يعلم أن للحب علامات تدل عليه، وثمارًا تظهر في القلب واللسان والجوارح، فإذا أراد ألا يغش نفسه فليضعها في موازين الحب، وليمتحنها بعلاماته.

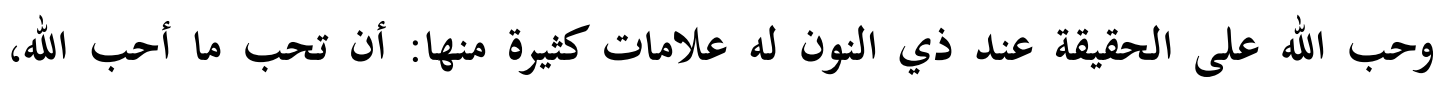
وتبغض ما أبغض الله، وتفعل الخير كله، وترفض ما يشغل عن الله، وأن لا تخاف في الله لومة

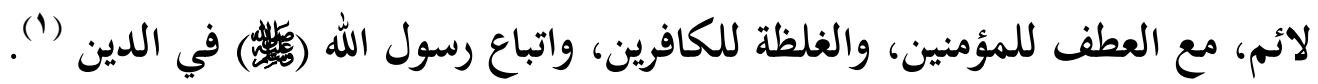

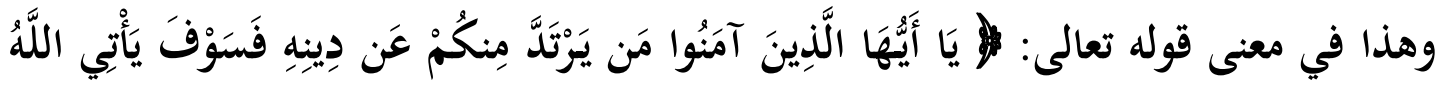

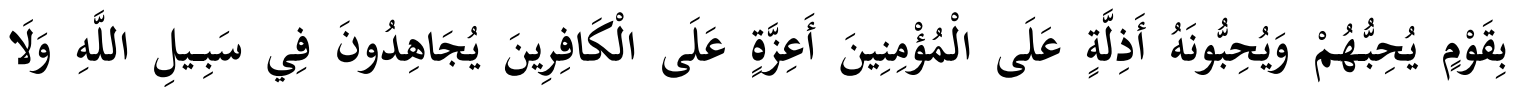

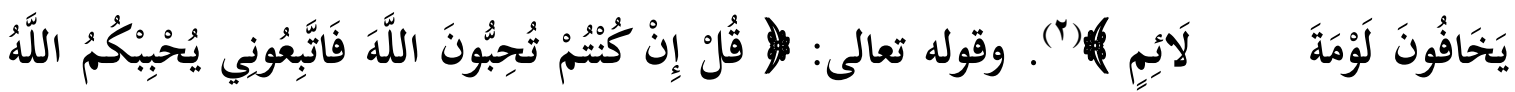

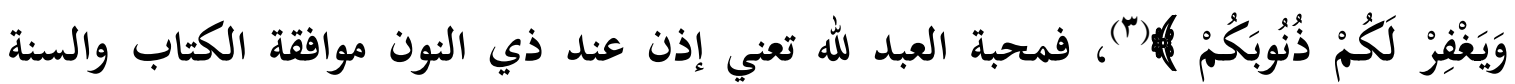
منهجًا وسلوكًا، وهدفها الأخير طاعة الله ومرضاته. ومثل ذي النون فيما ذهب إليه مثل المحاسبي حينما يقول: "المحبة في ثلاثة أشياء- لا يسمى محبًا لله عز وجل إلا بها- محبة المؤمنين في الله عز وجل، وعلامة ذلك كف الأذى

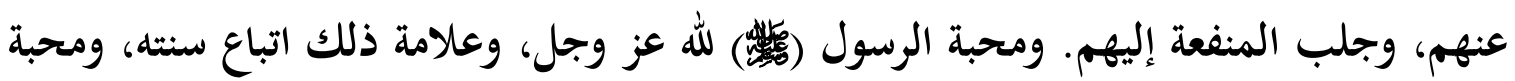

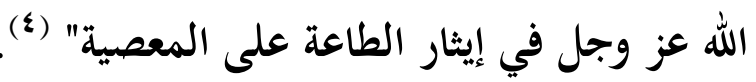

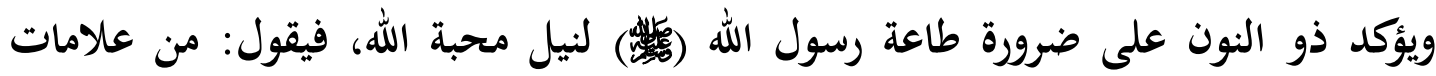

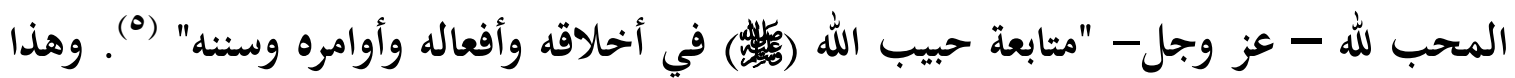

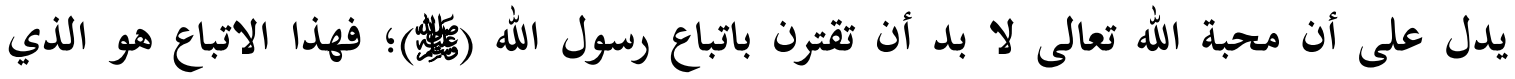

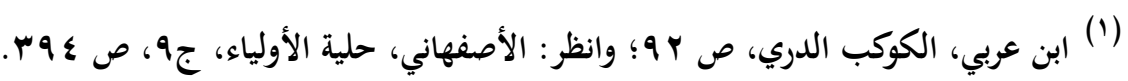

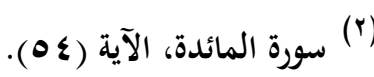

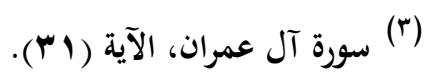

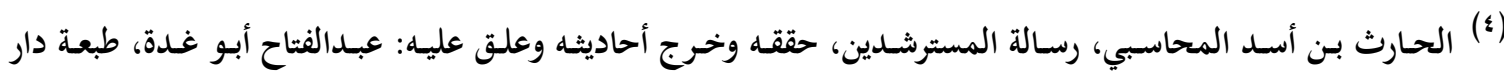

$$
\begin{aligned}
& \text { السلام، حلب، سوريا، د.ت، ص IV9 IVA ، IVV }
\end{aligned}
$$

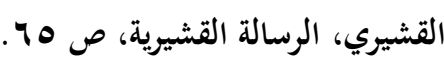


يوصل العبد إلى مرتبة المحبوبية، أي يصبح من أحباب الله تعالى، ومن يحبه الله فهو ذو حظ عظيم. يقول الإمام الغزالي (1): قيل العبد إذا علم أن الكمال الحقيقي ليس إلا لله، وأن كل ما

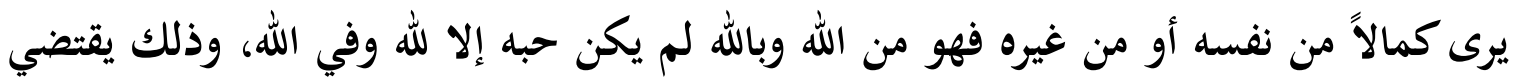

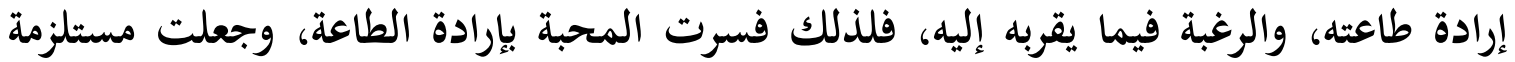

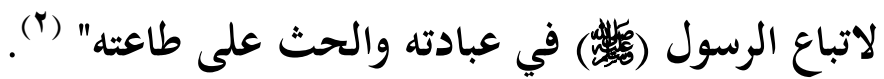
ويذكر ذو النون علامات أخرى لمحبة العبد لله، فيقول: "ثلاثة من أعلام الحب في الله: بذل الشيء لصفاء الود، وتعطيل الإرادة لإرادة الله، والسخاء بالنفس، والمشاركة في محبوبه لهاته ومكروهه بصفة العقد" ("). و"بذل الثيء لصفاء الود" تعني عند ذي النون أن يبذل العبد جهده، وأن يصرف أعماله

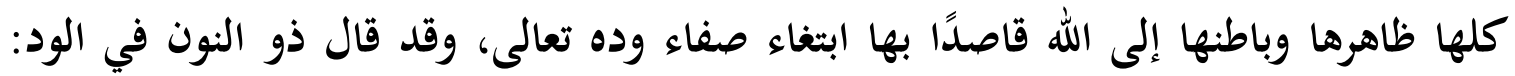
الحب لله عام، والود خاص؛ لأن كل المؤمنين يذوقون حبه وينالونه، وليس كل مؤمن ينال (घ) و

(1) الغزالي: هو محمد بن محمد بن محمد أبو حامد الغزالي المتكلم الأشعري، ولد بمدينة طوس بإقليم خراسان في سنة

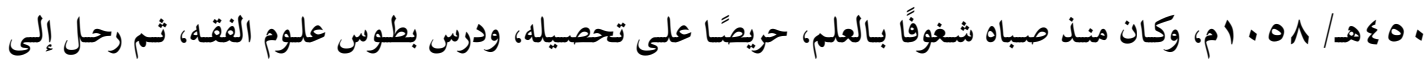

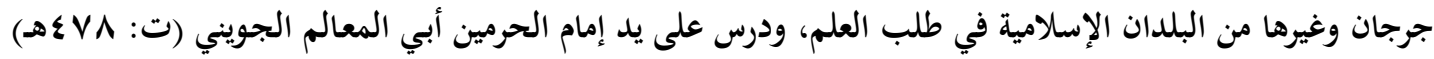

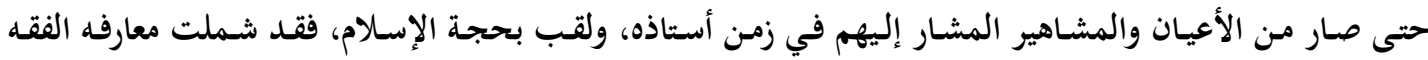

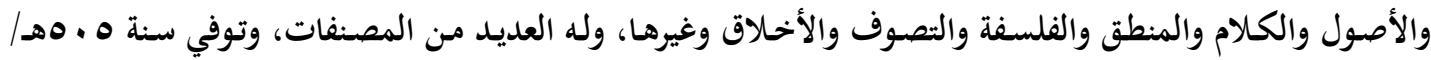
111111

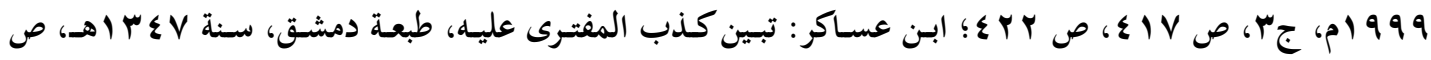

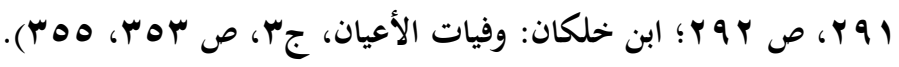

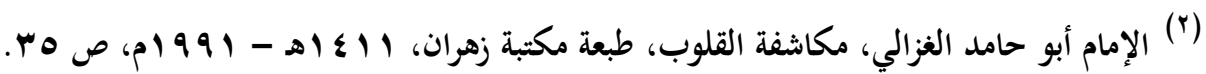

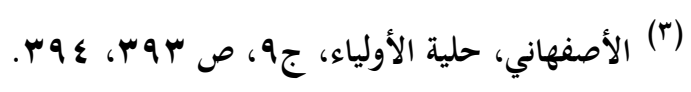

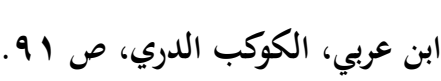


ويقول ابن عربي (1): ثبات الحب أو العشق أو الهوى أية حالة كانت من أحوال هذه الصفة، فإذا ثبت صاحبها الموصوف بها عليها، ولم يغيره شيء عنها، ولا إزالة عن حكمها، وثبت سلطانها في المنشط والمكروه، وما يسوء ويسر، وفي حالة الجهر والطرد، من الموجود الذي يجب أن يظهر فيه محبوبه، ولم يبرح تحت سلطانه لكونه مظهر محبوبه، سمي لذلك الك الك الكان

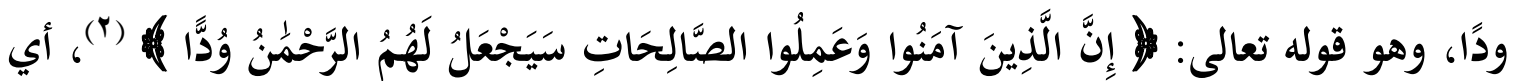

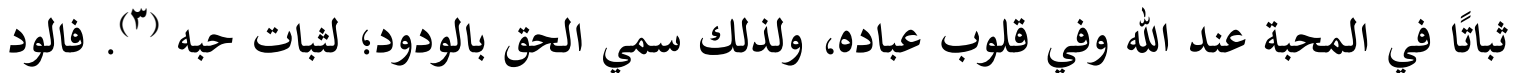
هو ثبات الحب كما أنه حالة خاصة لا ينالها كل مؤمن. وقول ذي النون: "تعطيل الإرادة لإرادة الله" تعني أن تكون إرادة المحب في سلوكه موافقة

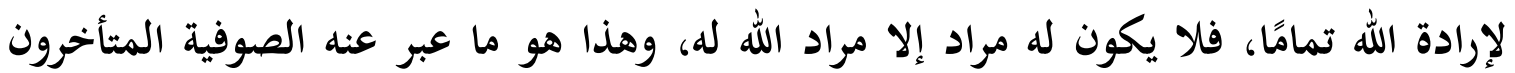
بالفناء عن إرادة السوي- وسوف نتناول ذلك في الحديث عن المحبة والفناء- ولكن ينبغي الإشارة هنا إلى أن ذا النون في قوله: "تعطيل الإرادة لإرادة الله" لا ينفي الإرادة الإنسانية

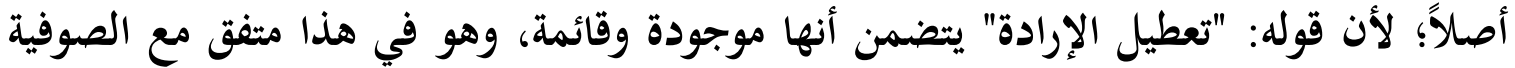
في إثباتهم الاستطاعة الإنسانية. يقول الكلاباذي: "وأجمعوا (الصوفية) أنهم مختارون

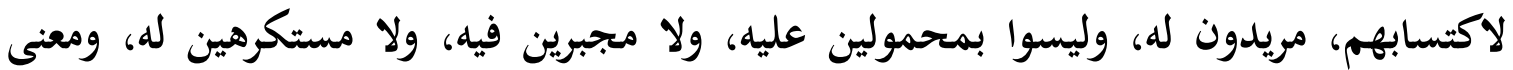

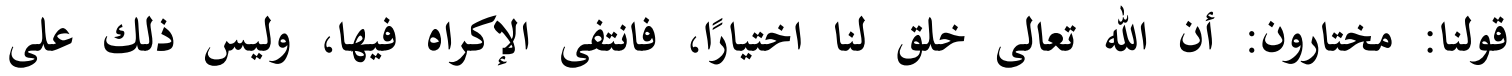

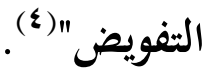

ابن عربي: أبو بكر محمد بن علي، شيخ الصوفية الأكبر، وشهرته محيي الدين باعتبار مصنفاته في التصوف وتفسيراته

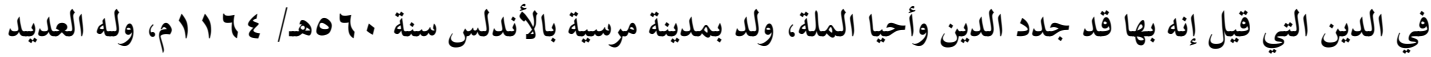

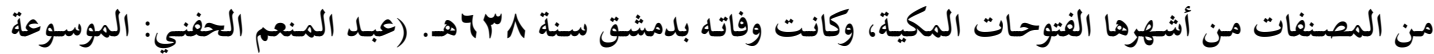

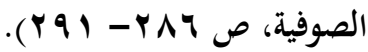

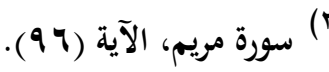

محيي الدين بن عربي، لوازم الحب الإلهي، تحقيق وتعليق: موفق فوزي الجبر، طبعة دار النمير، دمشق ، ص ؛م، هـ

$$
\text { الكلاباذي، التعرف لمذهب أهل التصوف، ص ז }
$$


أما قول ذي النون: "السخاء بالنفس، والمشاركة في محبوبه ومكروهه بصفة العقد" فهي أن يبذل المحب نفسه من أجل حبيبه، ويستوي عنده منه المحبوب والمكروه.

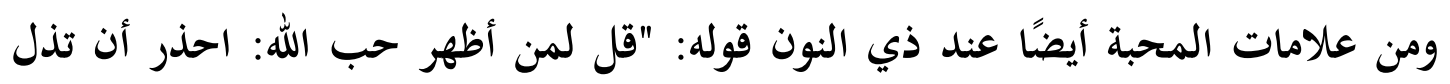

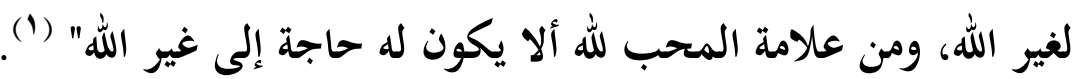

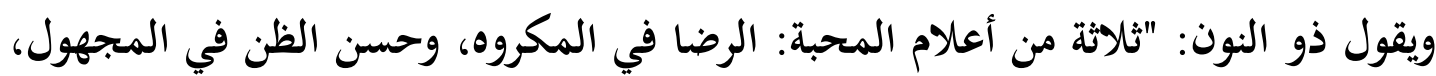

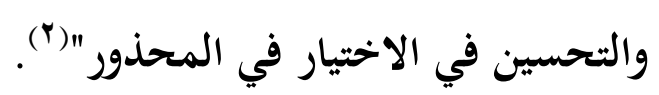
وأخيرًا من علامات المحبة الإلهية عند ذي النون "ترك كل شغل عن الهن الله؛ حتى يكون

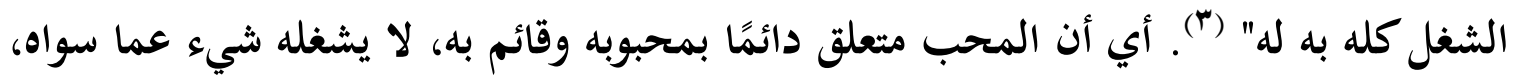

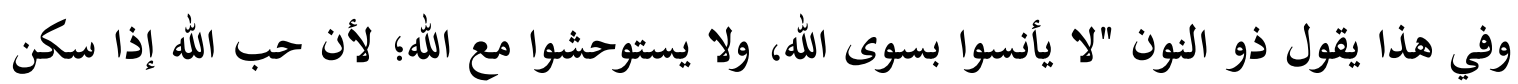

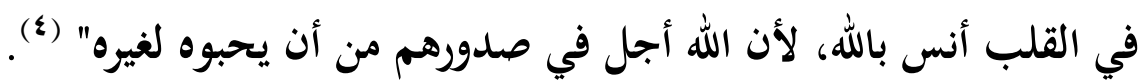

$$
\begin{aligned}
& \text { (1) (1) أبو حامد الغزالي، مكاشفة القلوب، ص rه1. }
\end{aligned}
$$

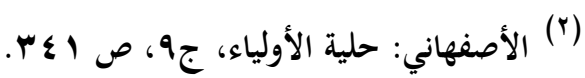

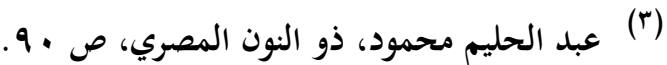

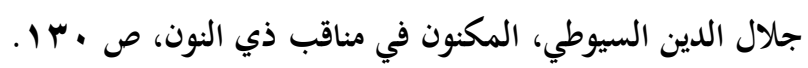




\section{المبحث الرابع \\ صفات المحبين وطبقاتهم عند ذي النون:}

ا

يصف ذو النون المحبين بصفاء القلب، وأنهم مشتاقون إلى الله، مؤتنسون به متعبدون له أملاً في نيل مَنَّه المعرفة، فيقول: "إن لله عبادًا ملأ قلوبهم من صفاء محض محبته، وهيج أرواحهم بالثوق إلى رؤيته، فسبحان من شوق إليه أنفسهم، وأدنى منه هممهم، وصفت له له

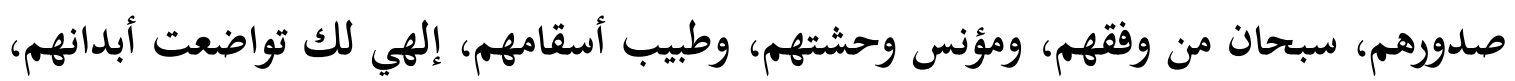
وإلى الزيادة منك انبسطت أيديهم، .... فنتحت لهم أبواب سماواتك، وأبحت لهم الجولان في ملكوتك، بك آنست محبة المحبين، وعليك معول شوق المشتاقين" (1). وعن مدى تعلق المحبين بربهم يقول ذو النون: "خوف النار إذا قيس إلى خوف القطع عن المحبوب، كقطرة الماء تقذف في أعظم المحيطات" (َ). وفي هذا المعنى يقول ذو النون: "لو أدخل الله المحب له النار ثم عذبه بأشد العذاب، ما نقص في قلبه من حبه شئًا، بل يزداد في

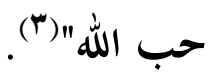

ومن أهم صفات المحبين لله عند ذي النون الزهد الحقيقي سأل أحدهم ذا النون: "متى يتم حبي لوبي؟ قال: إذا سمجت الدنيا في عينيك، وقذفت أملك فيها بين يديك، هذا زهد

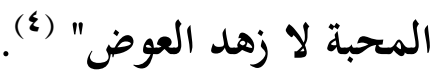
ومن صفاتهم أيضًا عنده شدة الحرص على مرضاة الله تعالى، قال أحدهم لذي النون: "متى أحب ربي؟ قال: إذا كان ما أسخطه عندك أمر من الصبر، وهذا أيضًا من استعذاب البلاء

للمحبة لا لغيرها" (•)

$$
\begin{aligned}
& \text { (1) ابن عربي، الكوكب الدري، ص צس 1. }
\end{aligned}
$$

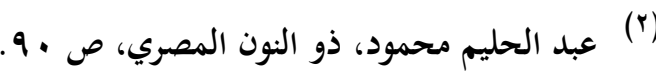

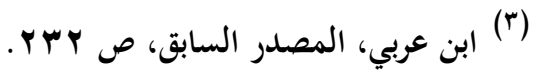

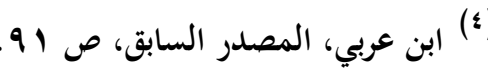

$$
\begin{aligned}
& \text { ابن عربي، المصدر السابق، نفس الصفحة. }
\end{aligned}
$$


كما يصف ذو النون المحبين بالحكمة في قوله: "إسكانك حب الله في صدرك يطلع ينابيع الحكمة من قلبك" (1)

أما أخص ما يميز المحبين في رأي ذي النون فهو كتمان سر المحبة بينهم وبين الله، وقد

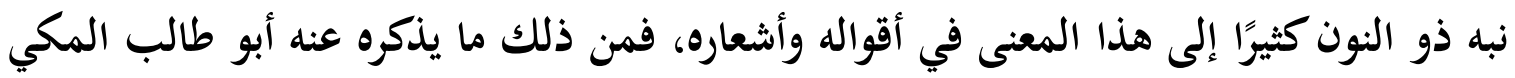

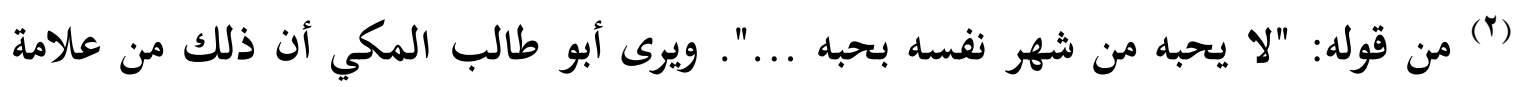

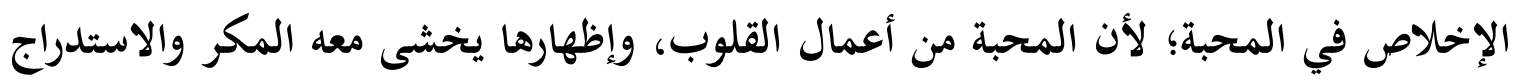

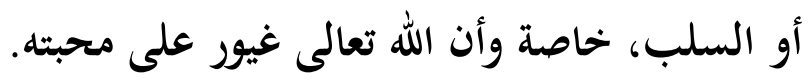

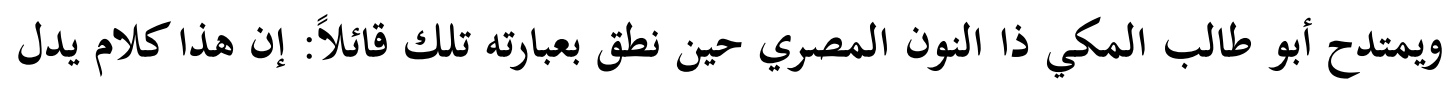

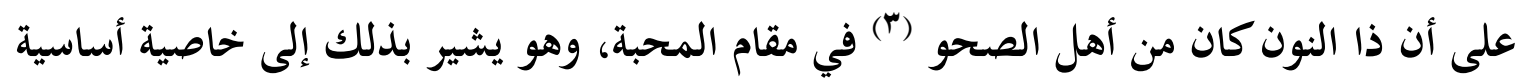

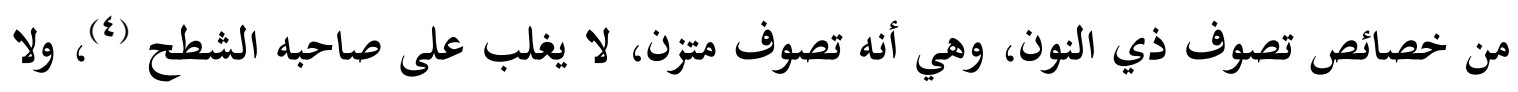
الأقوال المبهمة التي يمكن أن تؤخذ عليه.

$$
\begin{aligned}
& \text { وقد عبر ذو النون عن حاله هو في كتمان سر المحبة بينه وبين الله في قوله: }
\end{aligned}
$$

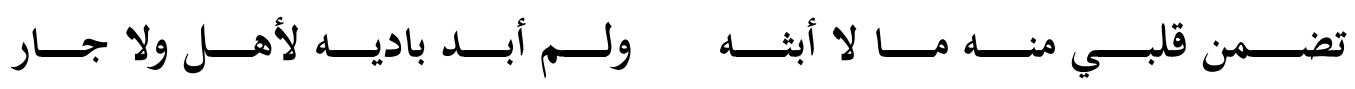

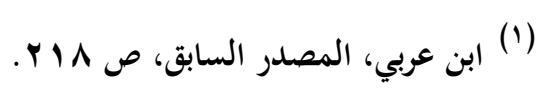

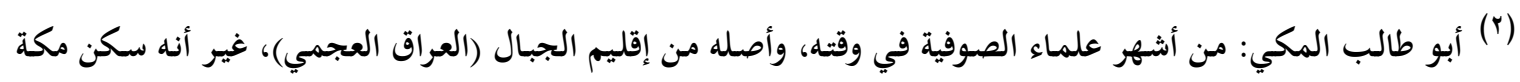

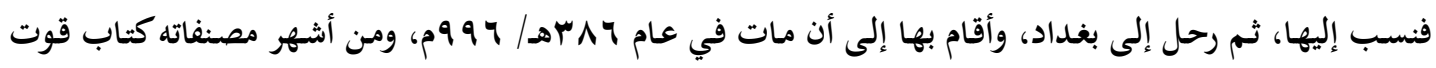

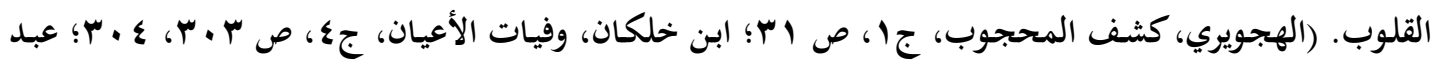

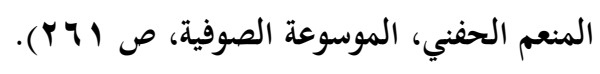

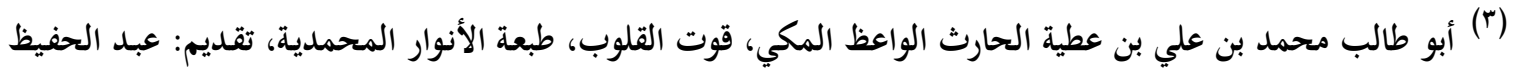

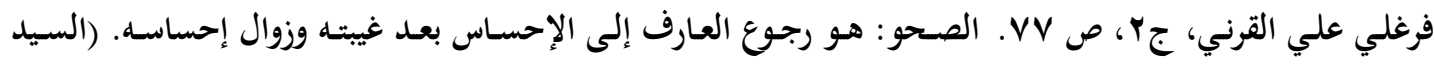

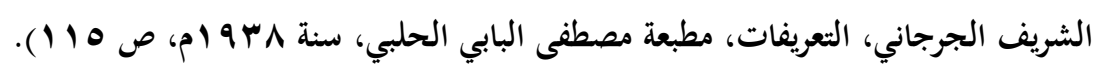

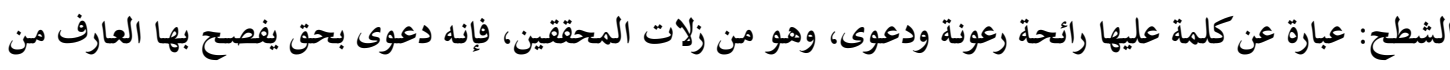

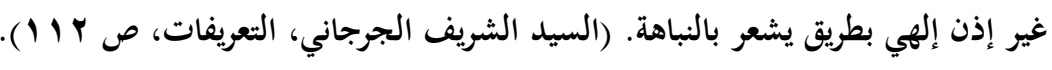




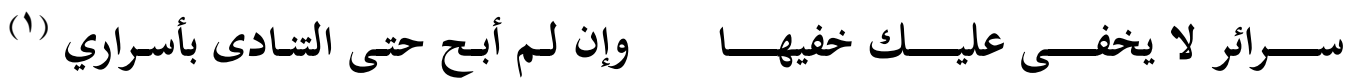

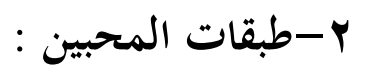

ومن الجدير بالذكر أن ذا النون لا يقف عند حد وصف الثف المحبين على هذا النحو الإجمالي

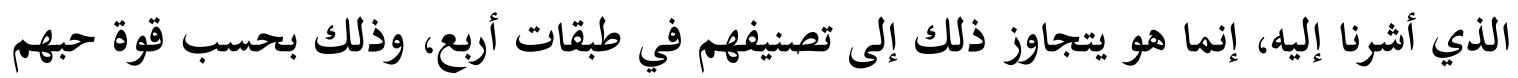

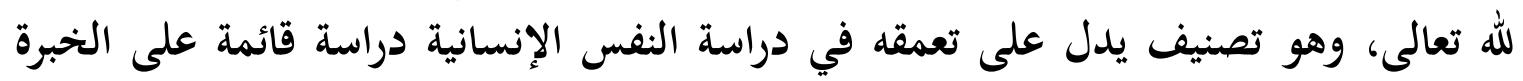
المباشرة.

ويظهر تصنيف المحبين عند ذي النون في قوله: "المحبون في الدنيا على أربع طبقات:

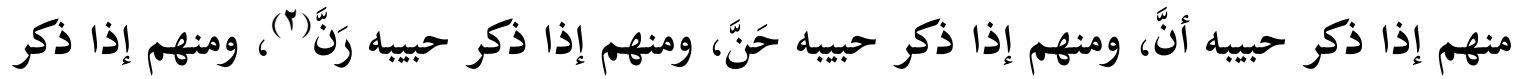

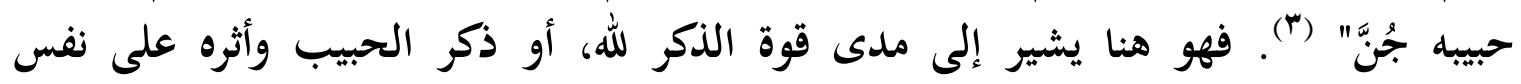

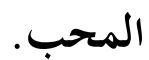

فالطبقة الأولى عند ذي النون طبقة "من إذا ذكر حبيبه أنَّ"، وهي أولى درجات المحبين،

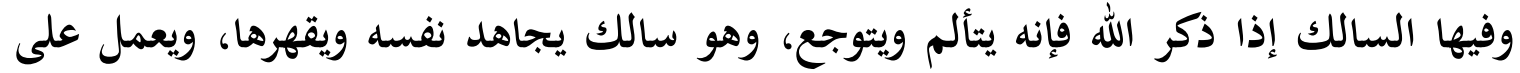

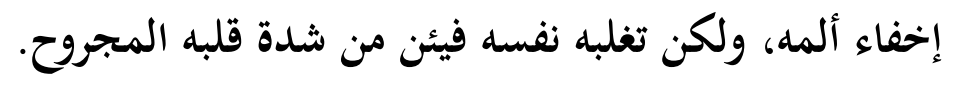

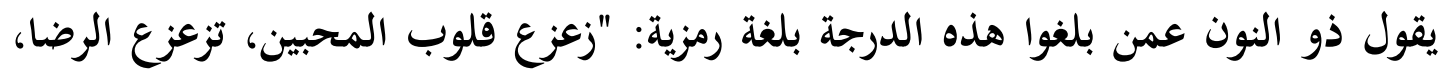

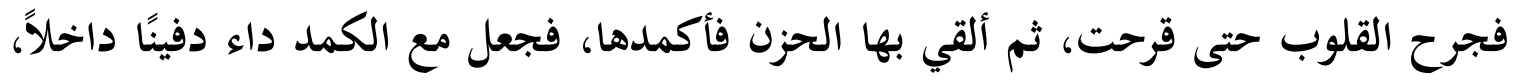

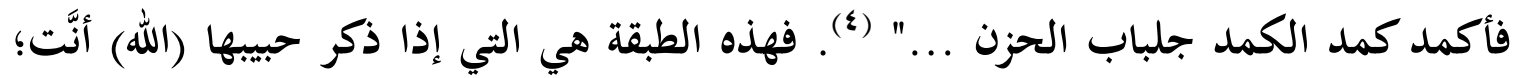
لأن قلوب أصحابها مجروحة مقروحة مليئة بالحزن وتعاني الكمد.

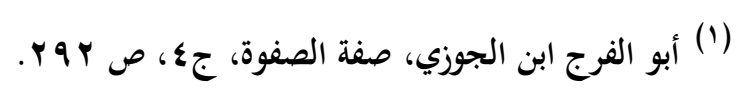

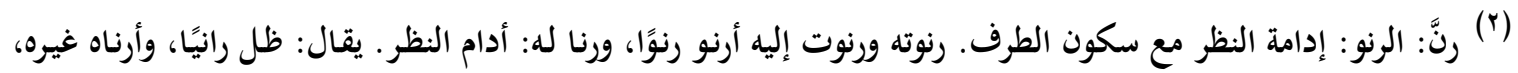

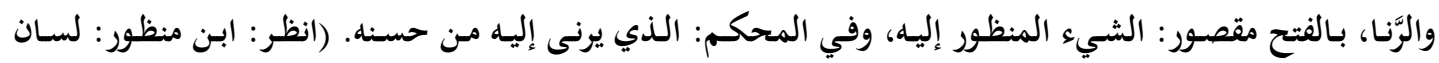

العرب، جr، مادة (رنا).

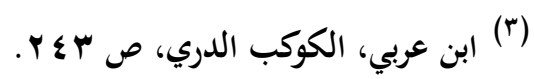

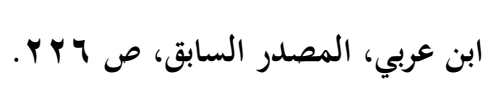


والطبقة الثانية من طبقات المحبين هي طبقة من "إذا ذكر حبيبه حَنَّ"، وهي طبقة خلصت من الآلام والتوجع، وارتفعت إلى مشاعر وعواطف الحنين إلى الله، والتلهف إليه، فهي ممتلئة بالحب لله. يقول ذو النون: "... فاذهب بالهموم حتى أفرجها (القلوب)، ووقع فيها معمعة إلى

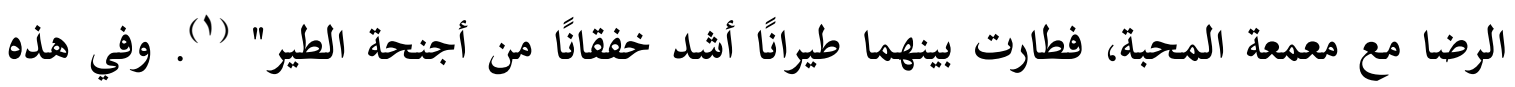
الدرجة بدأت تكتسب القلوب محبة الله ومننه من خلال حنينها إلى الله. والطبقة الثالثة هي طبقة من "إذا ذكر حبيبه رَنَّ"، ورن من رنا، واقتضى السجع أن يقول رن، وأصحاب هذه الطبقة هم الذين إذا ذكروا حبيبهم رنوا إليه، وانقطعوا له به فهم فانون عن لهن نفوسهم باقون بمحبوبهم، فهم في بداية حال الفناء. أما الطبقة الرابعة، وهي أعلى الطبقات، فهي طبقة المحبين الذين إذا ذكر الله جُنوا.

وينبغي الإشارة هنا إلى أن ذا النون لا يقصد الجنون الحقيقي، وإنما يقصد تلك الأحوال

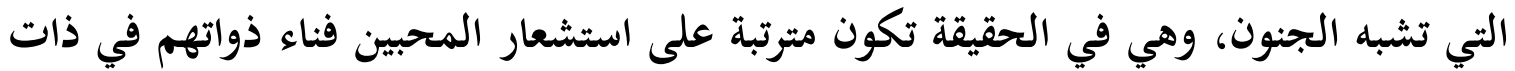

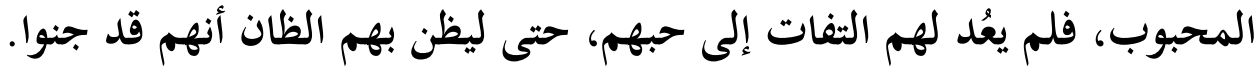

ويروى أن ذا النون في سياحاته قد التقى ببعض المحبين الذين بلغوا هذه الدرجة، فمن

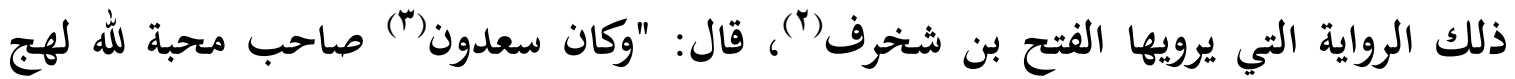
بالقول، صام ستين سنة حتى جف دماغه، فسماه الناس مجنونًا لتردد قوله في المحبة. قال

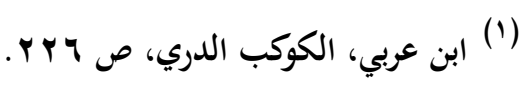

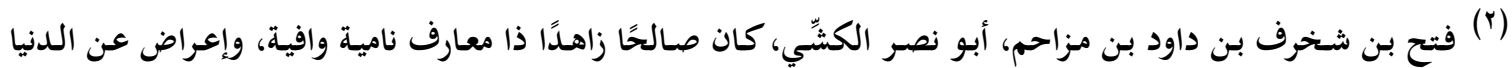

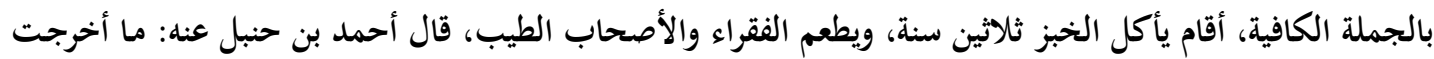

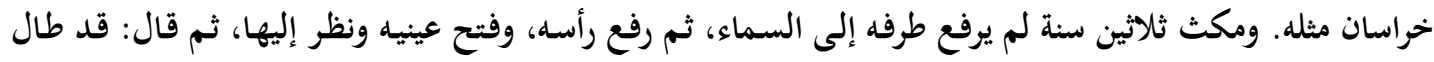

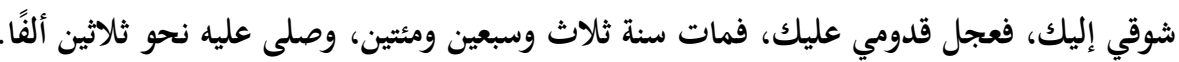

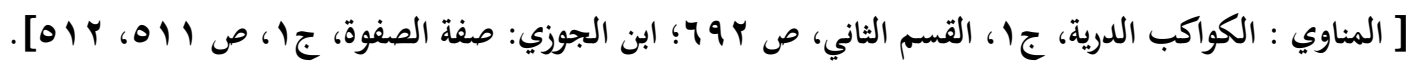

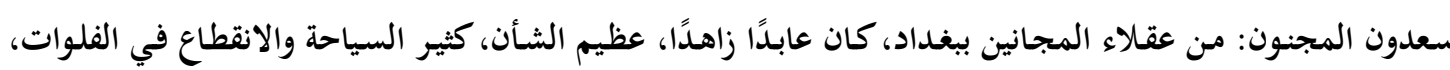

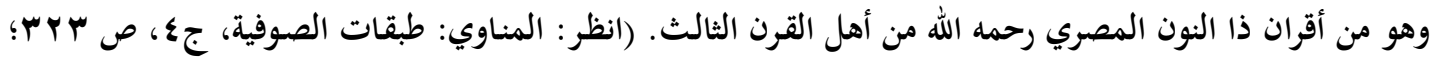

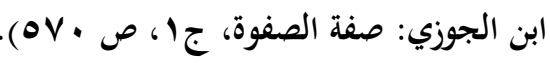


الفتح: فغاب عنا زمانًا، وكنت إلى لقائه مشتاقًا، لما كان وصف لي من حكمة قوله، فبينما أنا

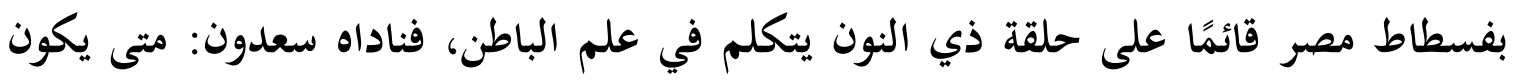

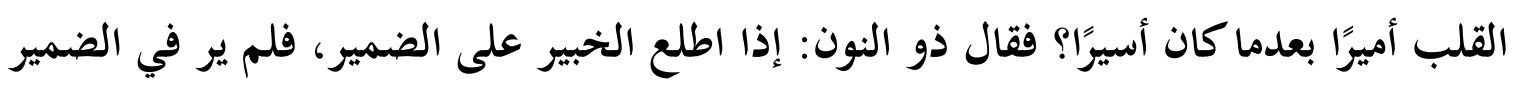

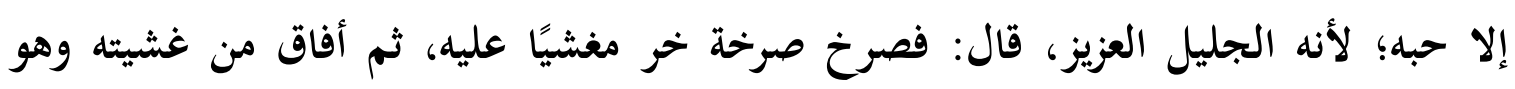

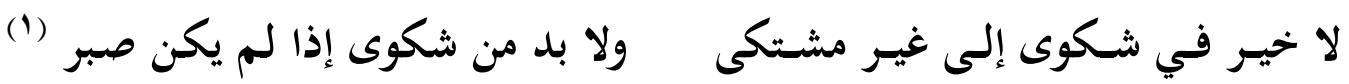

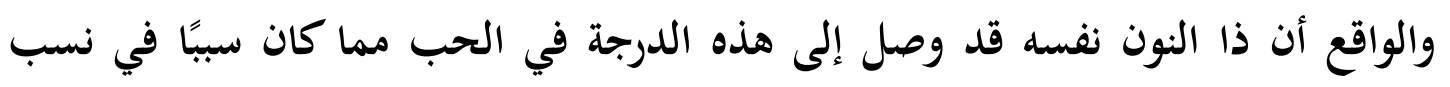

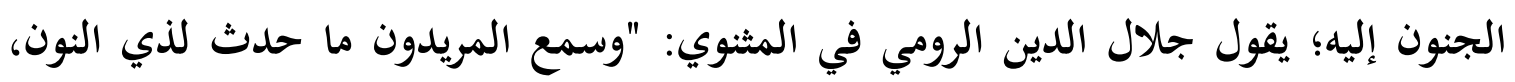

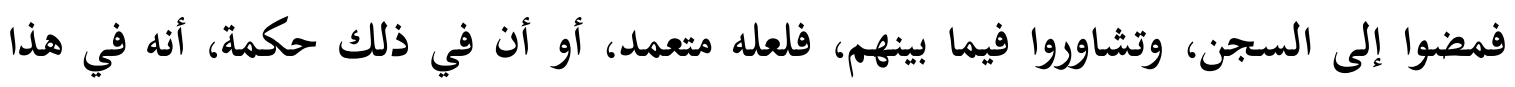

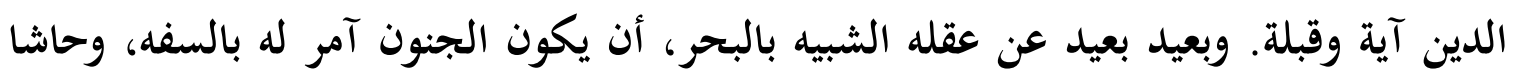

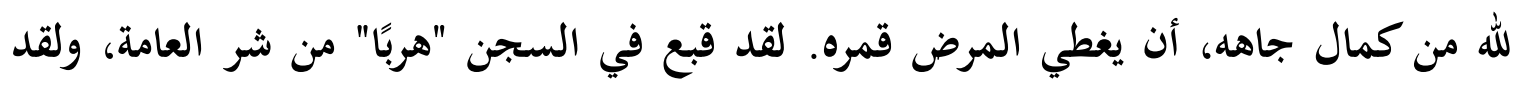
تظاهر بالجنون من عار العقلاء" (؟). ويفهم من كلام الرومي أن ذا النون قد وصل في حبل حب الله إلى درجة الفناء الذي هو سبيل

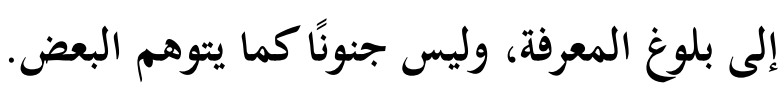

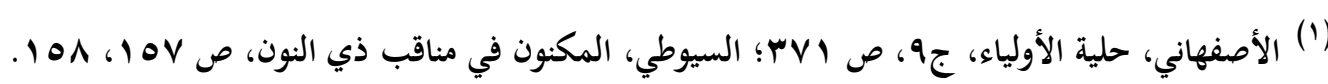

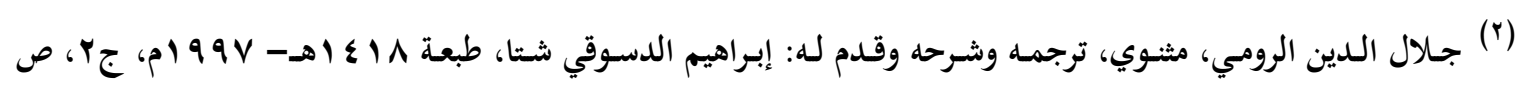




\section{المبحث الخامس \\ الرمزية في التعبير عن المحبة الإلهية عند ذي النون}

يستعمل الصوفية عادةً لغة الرمز (1)، وهم يحاولون التعبير عما يشعرون به في الحب الإلهي الذي يختلف عن أي حب معهود، وربما كان من دوافعهم لاستخدام الرمزية أنها أبلغ وأعظم تأثيرًا في نفوس سامعيها مما لو استعملوا لغة التصريح والتوضيح، إذ الرمزية لها عمل

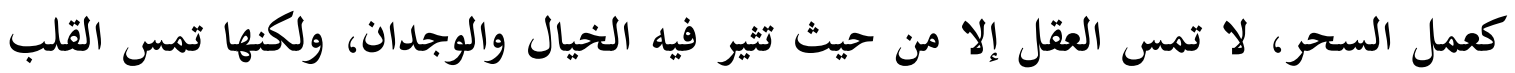
مسًا مباشرًا، ويعمق أثرها وتتضح معانيها مع التكرار، ولغة الحب الإلهي الرمزية لغة عالمية،

يستعملها جميع الصوفية، على اختلاف دياناتهم وأوطانهم (؟). ولعل من دوافعهم أيضًا غيرتهم على ما يتداولونه بينهم من معانٍ، وما يعالجونه من أفكار ومشاعر، أن يسيء فهمها أو استخدامها مَنْ ليس من أهلها، فهم يغطونها بحجاب مئم الرمز ، ويكتفون بالإشارة إليها من بعيد؛ لاعتقادهم أن القلوب المتفتحة والنفوس المهيأة للتلقي ستدرك هذه الإشارة، وتخترق حجاب الرمز، وتصل إلى المراد الذي كثيرًا ما يستعصي على من

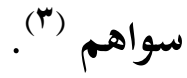
يقول القشيري: "هذه الطائفة يستعملون ألفاظًا فيما بينهم، قصدوا بها الكشف عن معانيهم لأنفسهم، والإجمال والستر على من باينهم في طريقهم، لتكون معاني ألفاظهم مستبهمة على الأجانب، غيرة منهم على أسرارهم أن تشيع في غير أهلها؛ إذ ليس حقائقهم

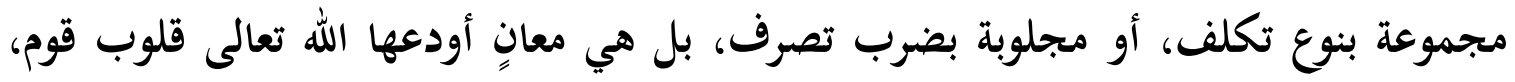
واستخلص لحقائقها أسرار قوم"( ).

(1) الرمز : معنى باطن مخزون تحت كحلام ظاهر لا يظفر به إلا أهله. (السراج الطوسي، اللمع في التصوف، اعتنى بنسخه وتصحيحه: رنولد ألن نكيلسون، طبعة بريل ليدن، ص ^بس).

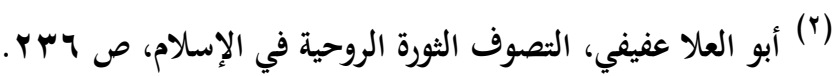
حسن محمود عبد اللطيف الثافعي، فصول في التصوف، طبعة دار البصائر، ص بـ r ب.

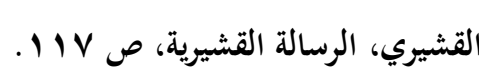


وذو النون على الرغم من أن أسلوبه في كتاباته بصفة عامة كان يتميز بالجزالة اللفظية،

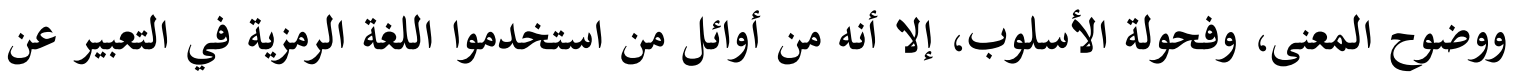

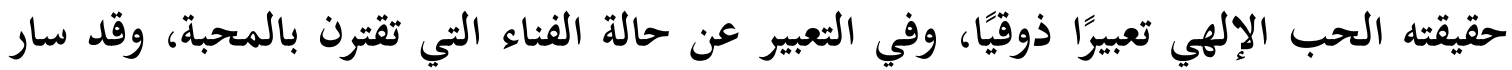
على نهجه وطريقته من جاء بعده من الصوفية.

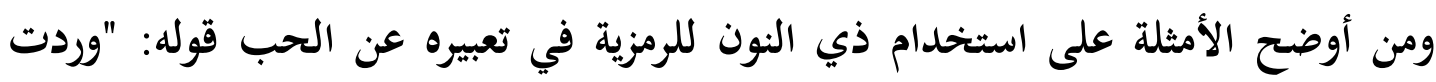

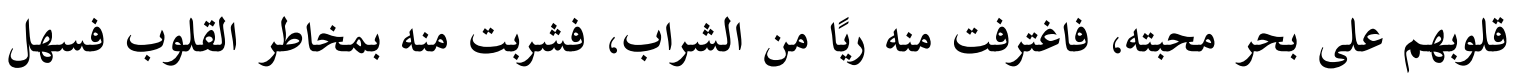
عليها كل عارض عرض لها عند لقاء المحبوب" (1).

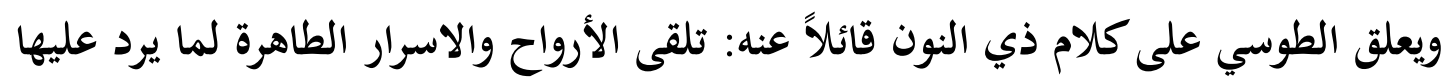
من الكرامات وتنعمها بذلك فشبه ذلك بالشرب لتهنيه وتنعمه بما يرد على قلبه من أنوار

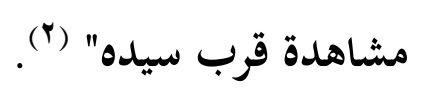

وثمة عبارات أخرى لذي النون مصطبغة بالرمزية مثل قوله: "لما أراد أن يستقيهم من كأس

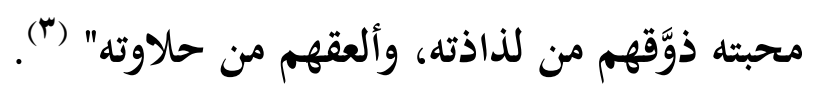

وقوله: "لو لزمنا الحياء من الله ما ذكرنا المحبة، وقد شربنا من كأس الدنيا" (\&). ومن دعاء

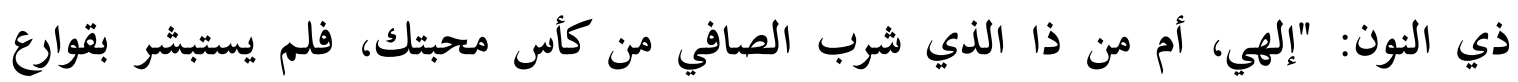

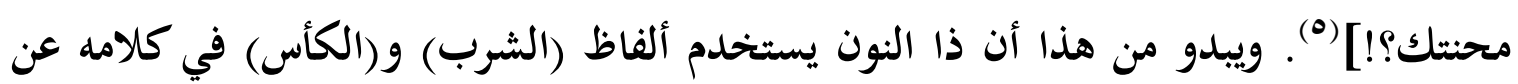
المحبة، وكلها تشبيهات واستعارات استخدمها هو وغيره من الصوفية لبيان ما للمحبة من آثار

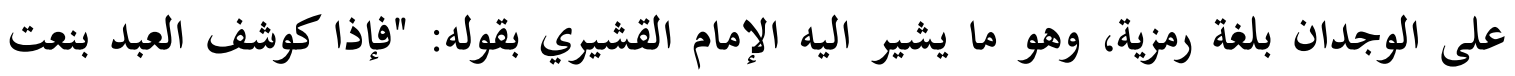

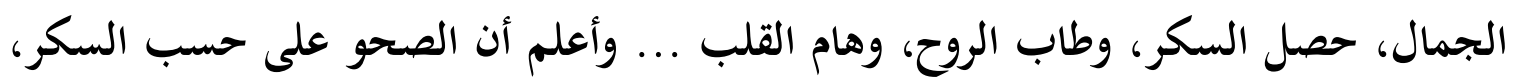

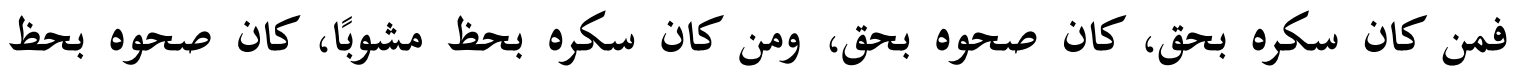

$$
\begin{aligned}
& \text { (1) الأصفهاني، حلية الأولياء، ج9، ص ^بr. }
\end{aligned}
$$

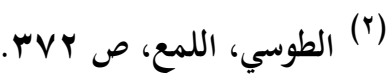

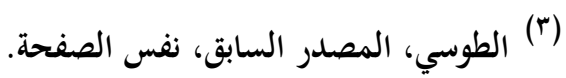

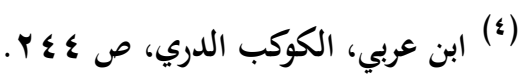

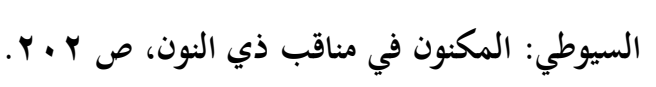


صحيح مصحوبًا، ومن كان محقًا في حاله، كان محظوظًا في سكره ... والعبد في حال سكره يشاهد الحال، وفي حال صحوه يشاهد العلم، إلا أنه في حال سكره محفوظ لا بتكلفة، وفي في حال صحوه متحفظ بتصرفه، والصحو والسكر بعد الذوق والشرب" (1). وإذا طبقنا معنى لفظ (الشرب) عند الإمام القشيري على عبارة ذي النون: "وردت قلوبهرم

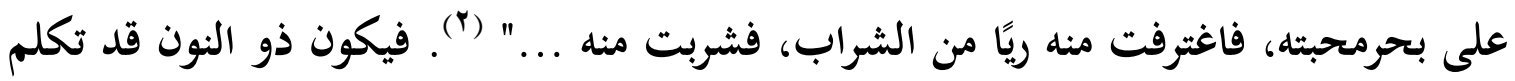
عن المحبة بلغة رمزية.

والحقيقة أن منهج الصوفي الوجداني، الذي يصف فيما يصف أحوالاً ذاتية عنده، لا بلد له اله

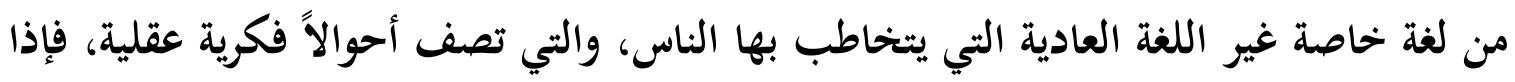

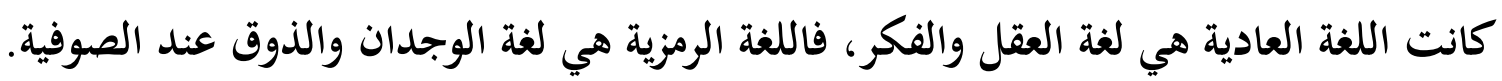

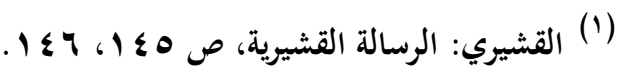

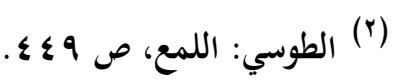




\section{المبحث السادس}

علاقة المحبة الإلهية ببعض الأحوال والمقامات عند ذي النون

ارتبطت بعض الأحوال والمقامات ؛ كالرضا، والشوق، والأنس، والفناء، والمعرفة بالمحبة

الإلهية عند ذي النون ؛ ووضح ذلك في كثير من اقواله وأشعاره ، وكان لها تأثير وتأثر بالمحبة

الإلهية عنده . الإندان.

أولاًا : المحبة والرضا:

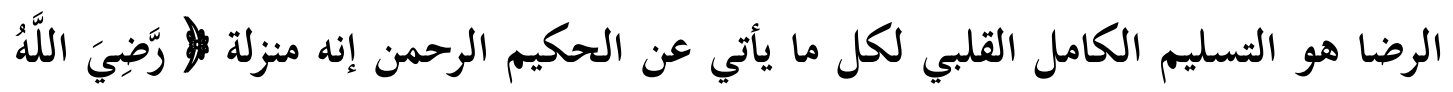
عَنْهُمْ وَرَضُوا عَنْهُ مَ) (1). ولن تجد بين المسلمين من لا يعترف بأن الرضا مقام سامِم، وأنه المقام الذي يجب أن يكون عليه كل مسلم، وذلك أن كل مسلم يعترف بأن الله أحكم الحاكمين،

وأنه أرحم الراحمين، ومن كان كذلك فلا بد من الرضا بقضائه (َ).

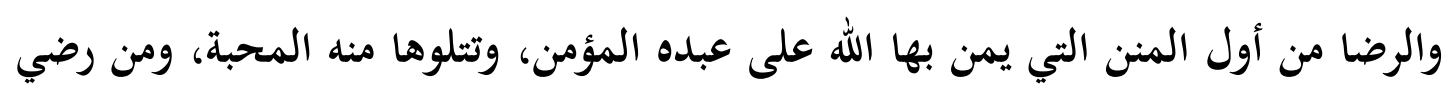

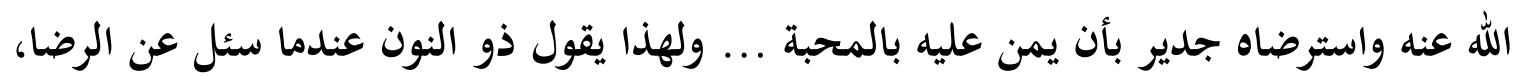
هو "سرور القلب بمر القضاء" (ب).

فالرضا مقام قلبي، إذا تحقق به المؤمن استطاع أن يتلقى نوائب الدهر وأنواع الكوارث بإيمان راسخ، ونفس مطمئنة، وقلب ساكن، بل قد يترقى إلى أرفع من ذلك، فيشعر بالسرور

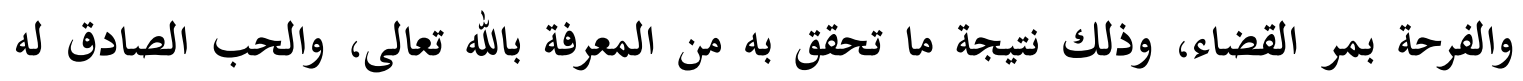

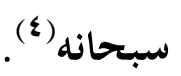

ويقرن ذو النون المحبة بالرضا في قوله: "لم يحب الله من لم يرض بقدره" (•). مما يفهم

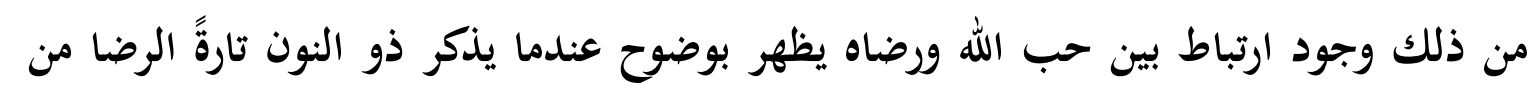

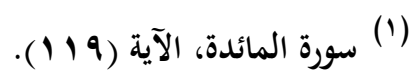

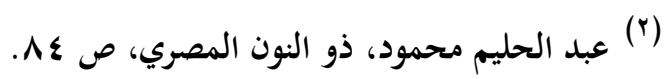

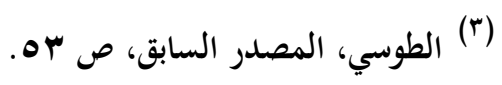

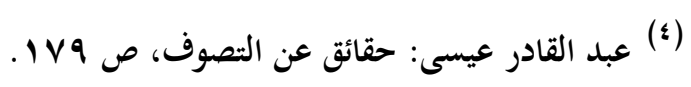

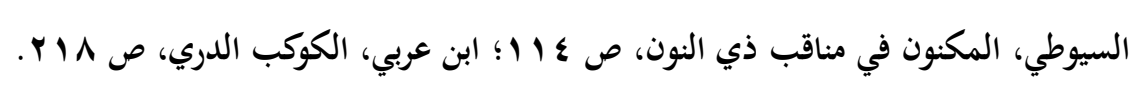


علامات المحبة، ويذكر تارةً أخرى المحبة من علامات الرضا؛ يقول ذو النون: "ثلاثة من أعلام

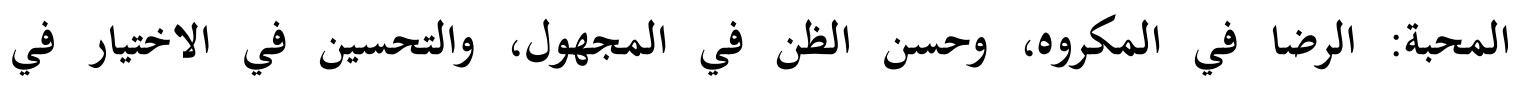

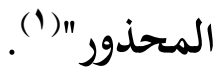

فأول أعلام المحبة عند ذي النون (الرضا في المكروه)، وهو يفسره قول ابن عجيبة (†) :

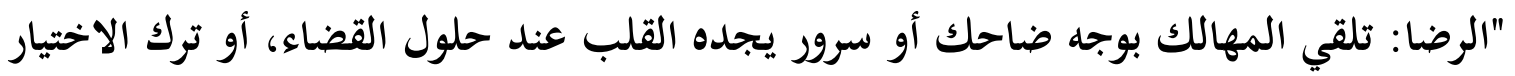
على الله فيما دبر وأمضى، أو شرح الصدور ورفع الإنكار لما يرد من الواحد القهار" (").

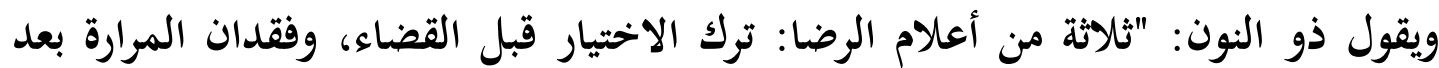

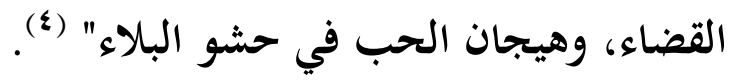
وقوله: "هيجان الحب في حشو البلاء" كعلامة من علامات الرضا، يفسره لنا ذو النون نفسه، كما يفهم من هذه الرواية: "دخل ذو النون المصري على بعض إخوانه - ممن كان يذكر

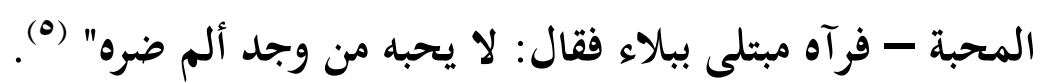

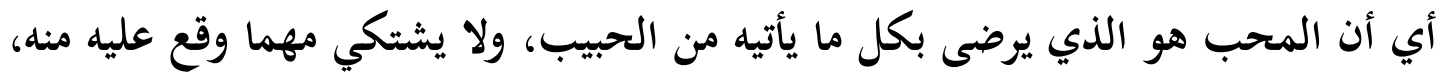

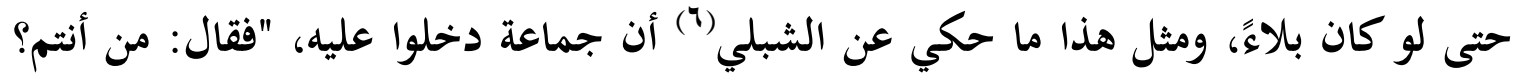

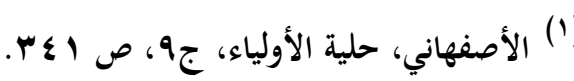

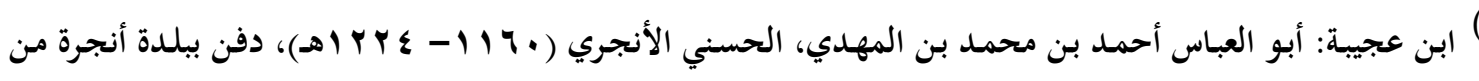

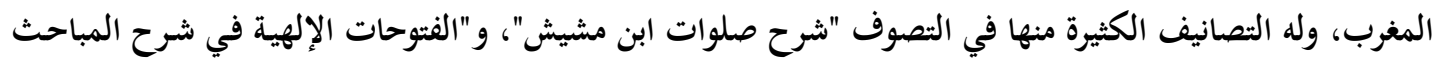

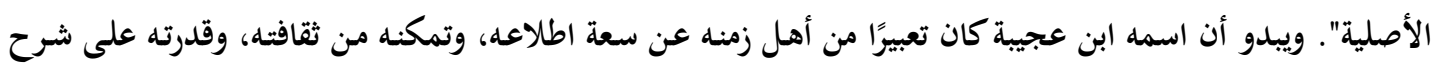

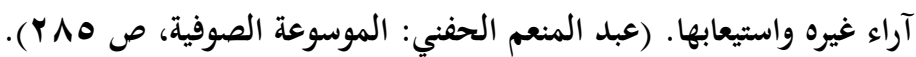

$$
\begin{aligned}
& \text { عبد القادر عيسى، حقائق عن التصوف، ص VV9. }
\end{aligned}
$$

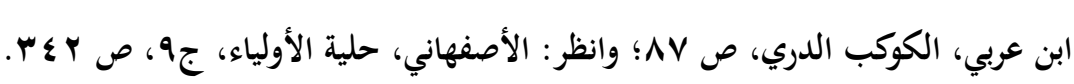

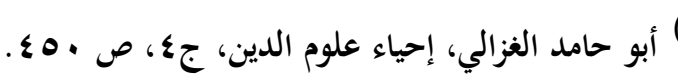

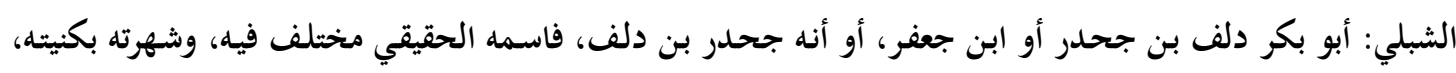

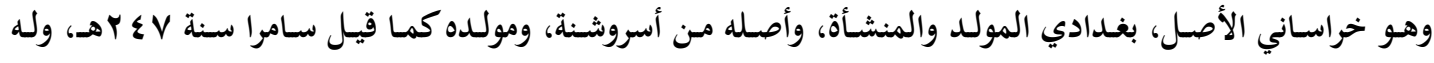

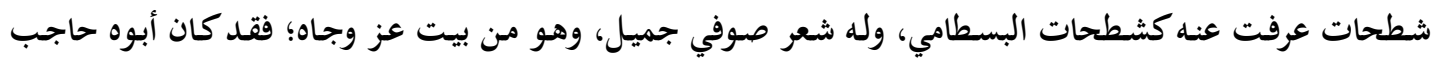

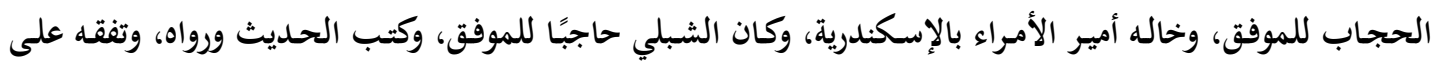

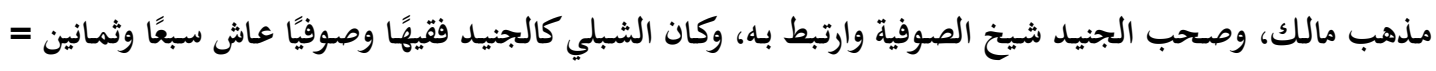


قالوا: نحن أحباؤك. فأقبل، ثم رماهم بالحجارة فهربوا منه، فقال لهم: تهربون مني؟! لو كنتم أحبائي لما فررتم من بلائي" (1) . ويربط ذو النون كذلك بين المحبة والرضا حين سئل عنهما، فقال: "زعزع قلوب المحبين تزعزع الرضا، فجرح القلوب حتى قرحت، ثم ألقى بها في الحزن، فأكمدها، فجعل مع الكمد داءً دفينًا داخلاً، فأكمد كمد الكمد جلباب الحزن ... وطفقت النفس متململة تهش إلى الى القلب ليكبحه، فوقع وثائق القلب في لجام النفس، فكبحها وطردها، فاستنار القلب بنور العز، فاعتز بالرضا والمحبة، فطرد استحواذ الشيطان عنه طردًا، وطرد النفس مع الهوى ..." (؟). نستخلص مما سبق وجود ارتباط وثيق بين المحبة والرضا عند ذي النون لتوقف كلٍ منهما على الآخر. ثانياً : المحبة والثوق: الشوق في اللغة احتياج القلب إلى لقاء المحبوب، وكذلك هو في اصطلاح أهل الحقيقة، حتى قال بعضهم: هو احتراق الأحشاء، وتلهب القلوب، وتقطع الأكباد، وقيل: علامته قطع الجوارح عن الثهوات. وقيل: علامته حب الموت مع كون الإنسان في العافية والراحة ("). يقول الجنيد: سمعت السري يقول: الثوق أجل مقام للعارف إذا تحقق فيه، وإذا تحقق في الشوق لها عن كل شيء يشغله عمن يشتاق إليه (؛).

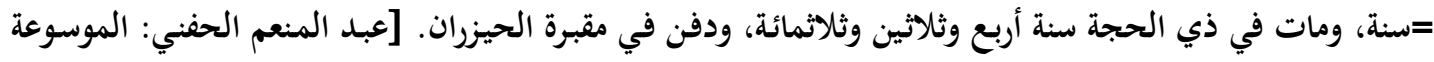

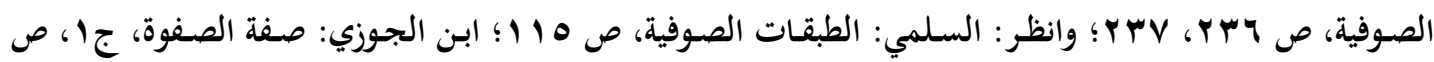

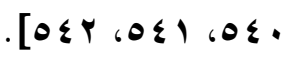

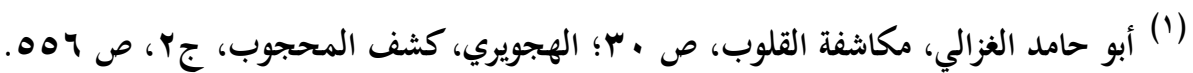

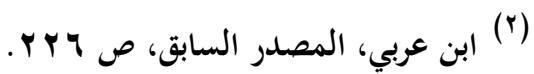

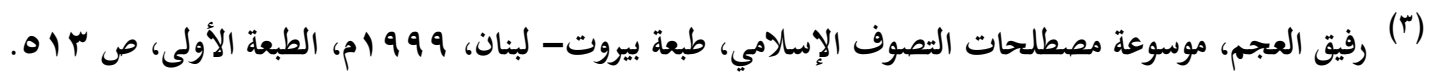

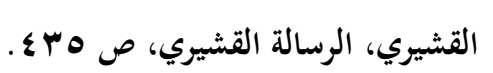


ويربط الصوفية بين المحبة والشوق، يقول ابن عببي: "الشوق للمحبة وصف لازم تابع لها،

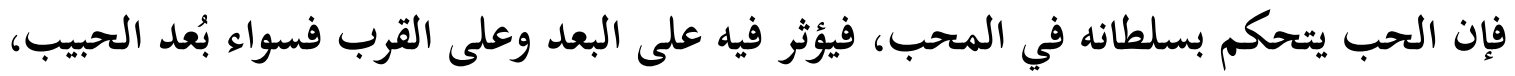

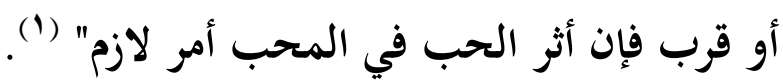

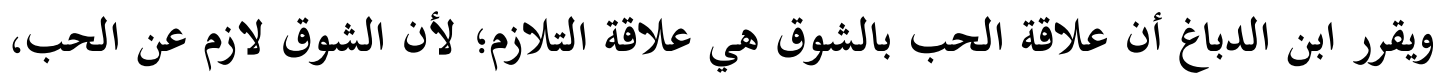

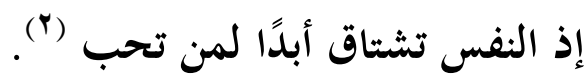
ومن المعروف أن الملزوم متقدم على لازمه. وسئل ابن عطاء عن الشوق: فقيل له الشوق أعلى أم المحبة ؟

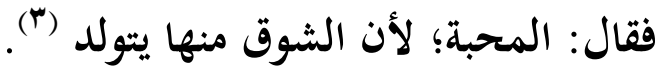

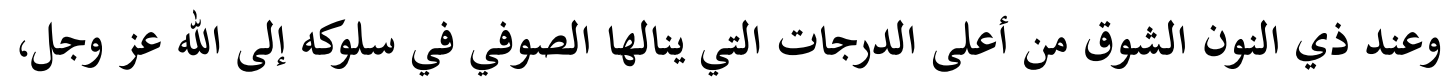

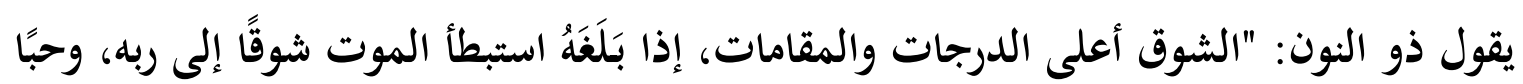

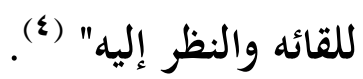

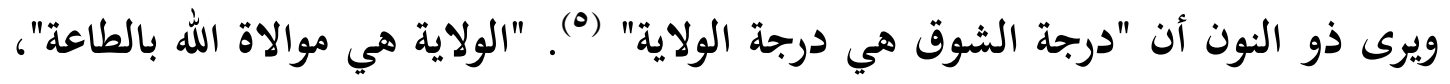

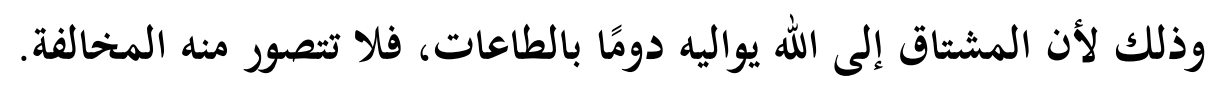

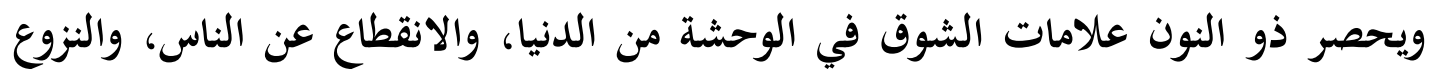

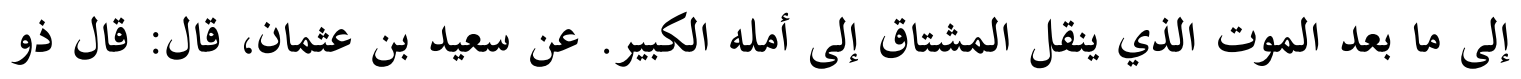

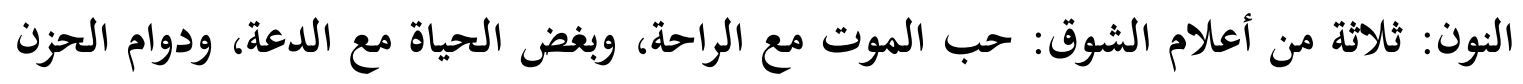

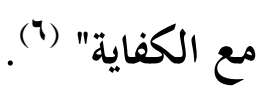

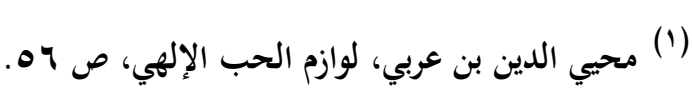

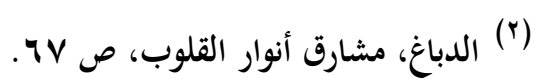

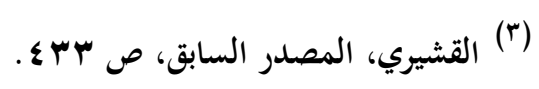

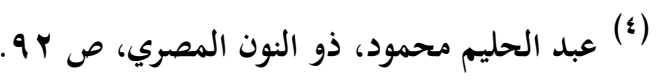

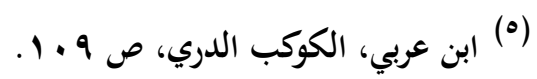

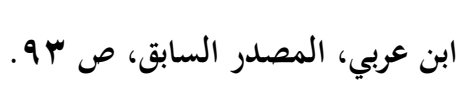


وقد سأل أبو محمد عبد الله بن سهل ذا النون: متى أشتاق إلى ربي؟ قال: إذا جعلت

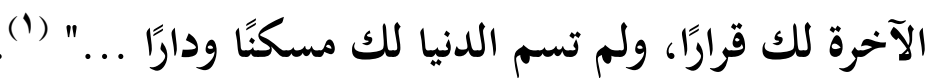

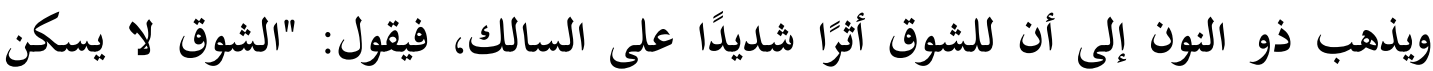

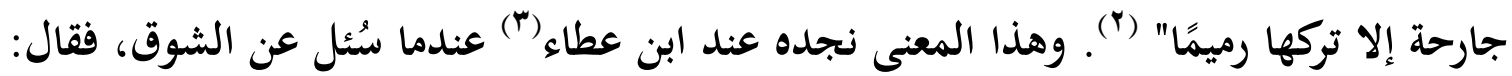

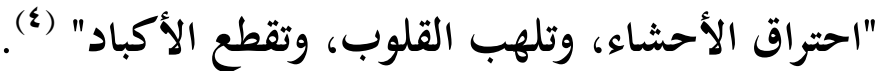

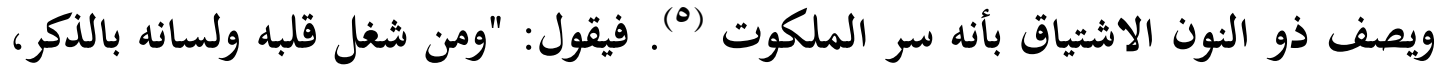

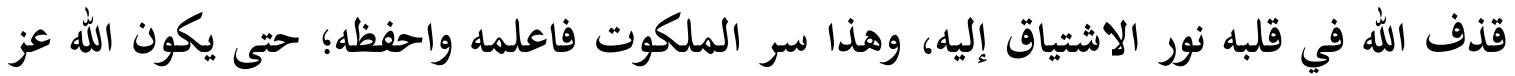

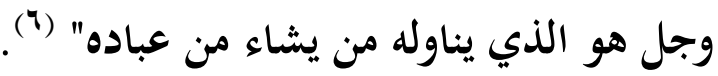

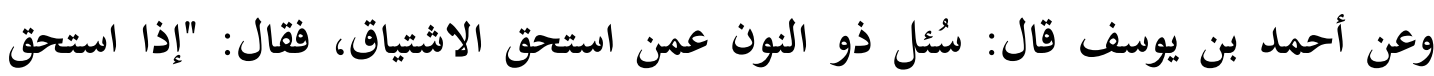

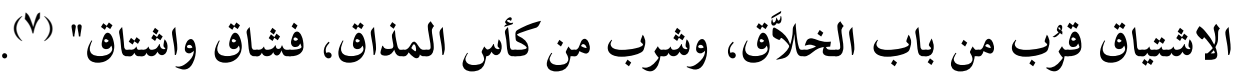

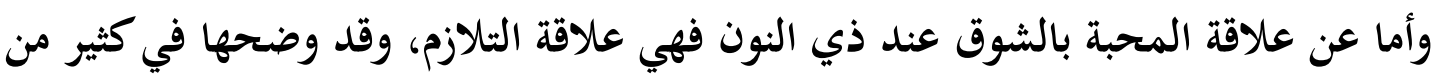

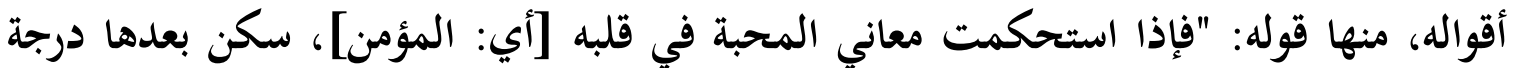

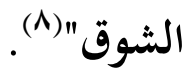

$$
\begin{aligned}
& \text { (1) الأصفهاني، حلية الأولياء، ج9، ص ب جـ. }
\end{aligned}
$$

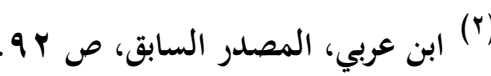

(ז) ابن عطاء الله السكندري: أحمد بن محمد بن عبد الكرئ الكريم بن عطاء الله، وكنيته تاج الدين، وينسب إلى الإسكندرية؛

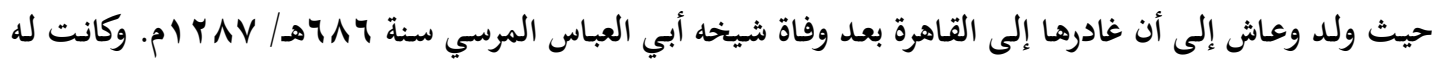

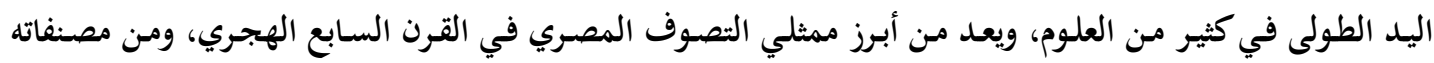

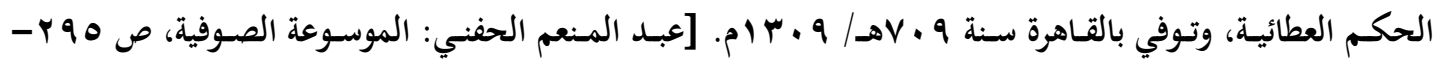

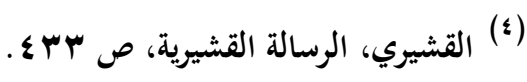

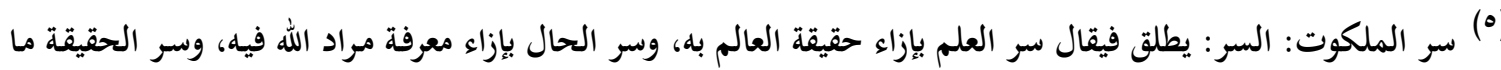

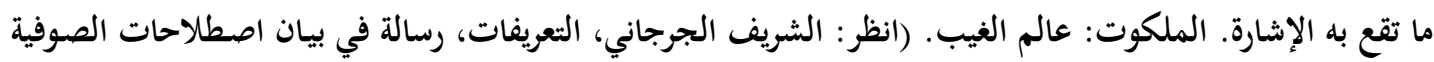

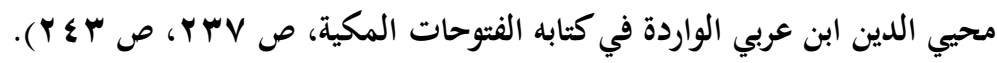

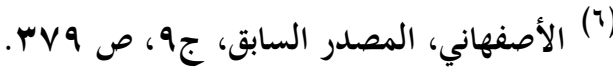

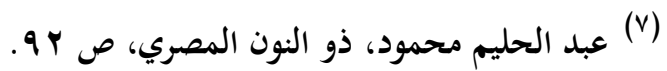

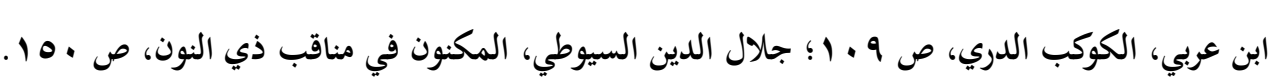


وعندما سُئل ذو النون: كم الأبواب على الفطنة؟ قال: أربعة، أولها الخوف، ثم الرجاء، ثم المحبة، ثم الشوق. ثم قال: ولها أربعة مفاتيح: ... وحب العبادة والثوق مفتاح باب المحبة، الثال

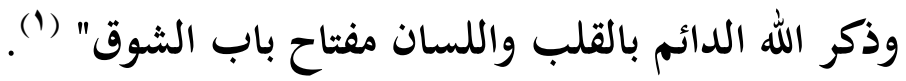
ويذهب ذو النون إلى أن المحبين لا غنى لهم عن الشوق والاشتياق إلى الحبيب، فيقول: "ما العيش عندي إلا عيش المشتاقين؛ لأنهم ما داموا محبين مجردين عن لباس الشوق، فهم

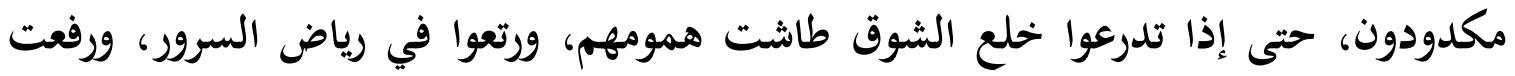

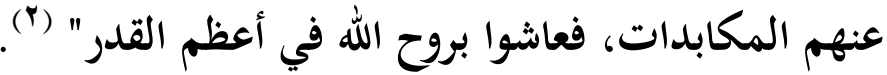
ويعني ذو النون بهذا أن المحبين عندما يتلبسون بالشوق تزول عنهم الهموم، وينعمون بالسعادة، وترفع عنهم الشدائد. وقوله: "عاشوا بروح الله في أعظم القدر"، أن المحبين عاشوا بعناية الله في أعظم مكانة، وهي الولاية (درجة الشوق)، ولا يعني ذو النون بذلك معنى الكنى الاتحاد أو الحلول؛ لأنه متصوف، يقوم تصوفه على الكتاب العزيز والسنة النبوية الشريفة. وقد جاء وصف المشتاقين المتعلقين بحب الله في كلام ذي النون على الوجه الآتي:

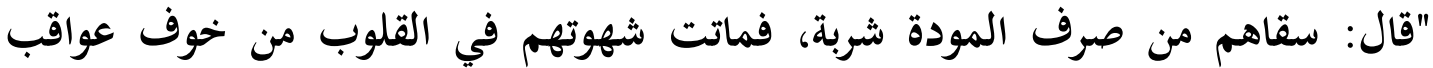

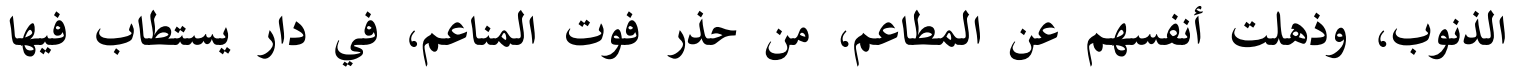

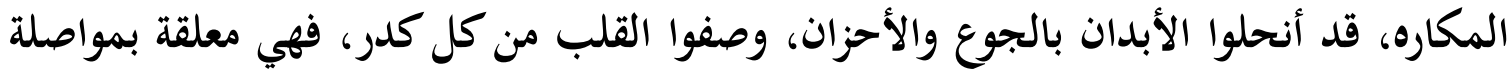

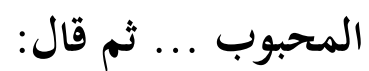

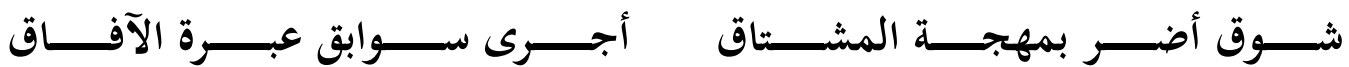

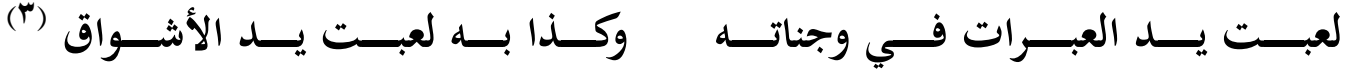
يتضح مما سبق ارتباط المحبة بالشوق عند ذي النون، ووجود علاقة تلازم بينهما؛ فالشوق لازم عن المحبة؛ لأن المحب في شوق دائم للمحبوب.

$$
\begin{aligned}
& \text { (1) ابن عربي: الكوكب الدري، ص } 9 \text {. } 1 .
\end{aligned}
$$

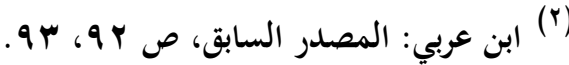

$$
\begin{aligned}
& \text { ابن عربي، الدصدر السابق، ص \& آلا. }
\end{aligned}
$$


ثالثاً : المحبة والأنس:

كما تكلم ذو النون في الشوق كلازم من لوازم المحبة، تكلم كذلك في أخص لوازمها،

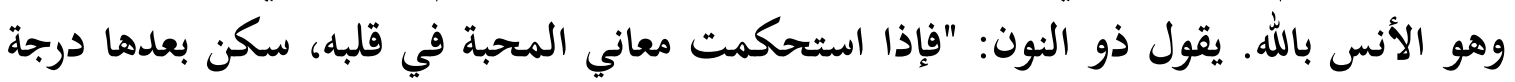

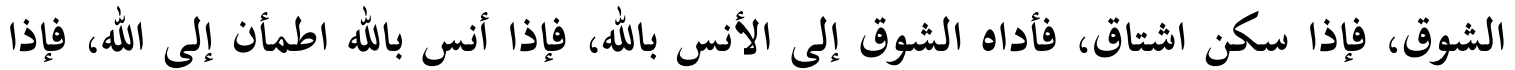

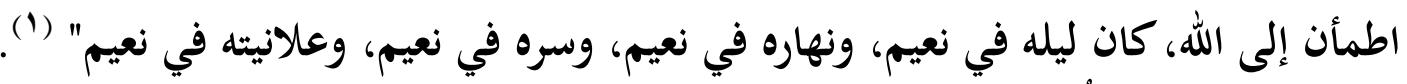

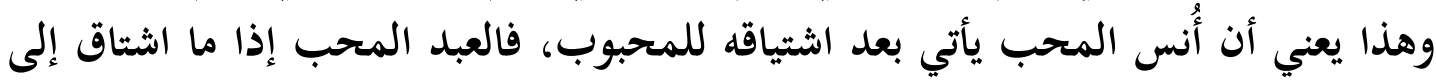

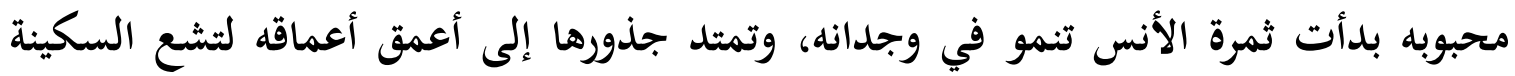
والطمأنينة والفرح في جنبات فرة الانس فؤاده

ويعرف ذو النون الأنس بأنه "انبساط المحب واده إلى المحبوب" (َ). والمحب هو الصوفي

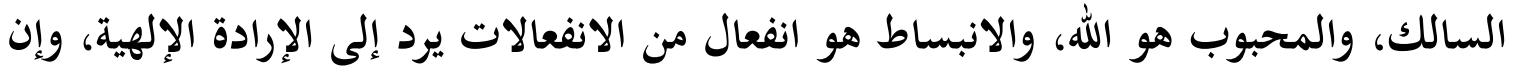
شئت قلت هو وارد يرد على قلب الصوفي من غير تعمد منه ولا اجتلاب.

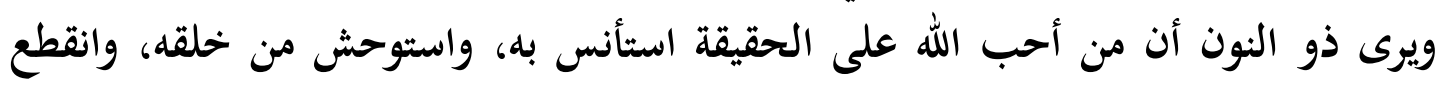
عن كل شيء سواه؛ يقول ذو النون:

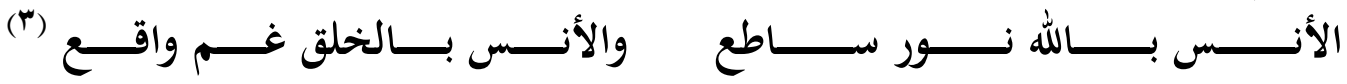

ويقول أيضًا: "الأنس بالله صفاء القلب مع الله، والثفرد بالله الانقطاع من كل شيء سوى

ويكرر ذو النون نفس المعنى بعبارات أخرى، فيقول: "ثلاثة من أعلام الأنس بالله تعالى:

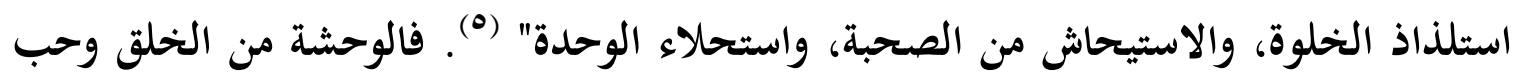

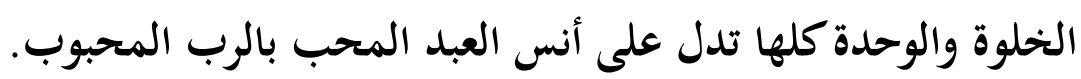

$$
\begin{aligned}
& \text { (1) السيوطي: المكنون في مناقب ذي النون، ص • 10 1) }
\end{aligned}
$$

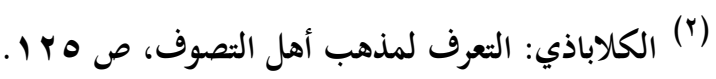

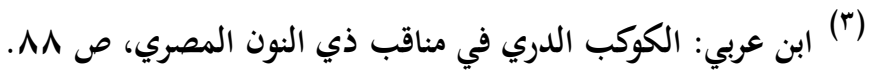

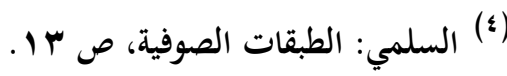

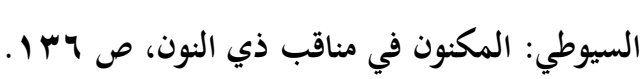


يقول ذو النون: "إذا رأيته يؤنسك بخلقه، فإنه يوحشك من نفسه، وإذا رأيته يوحشك من

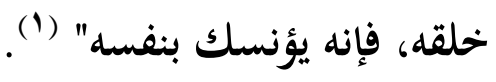

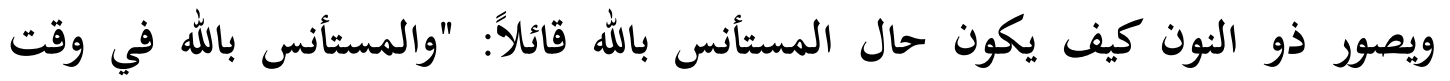

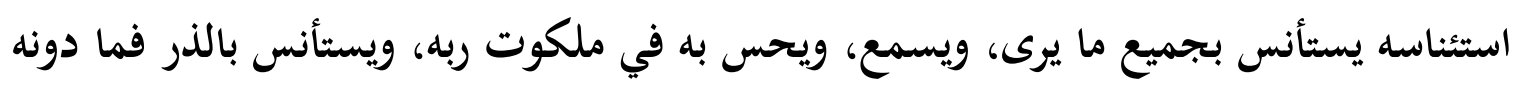

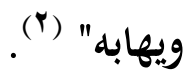

قال عبد الله بن خلف: ذكرت ذلك لأحمد بن أبي الحواري فقال: "صدق أبو الفيض

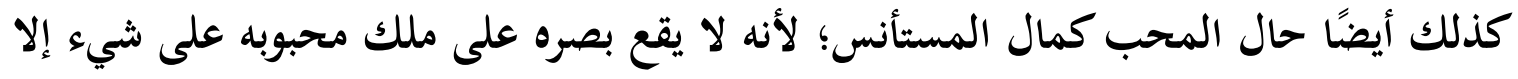
كان حب المحبوب موجود فيه (").

ومعنى ذلك أن المستأنس بالله يحب كل شيء في في الوجود من إنسان وحيوان وجماد،

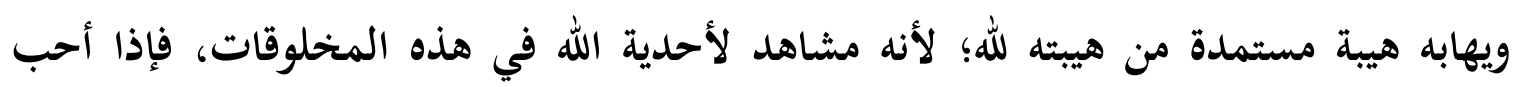

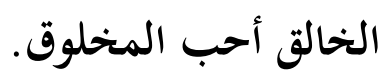

ويذهب ذو النون إلى أن المحب لله يستأنس بالله، ولا يشعر بغربة حتى لو ألقي في النار؛

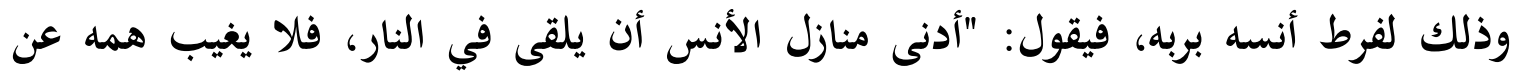

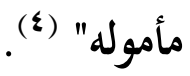
نستخلص مما سبق أن الأنس بالله عند ذي النون من لوازم محبته تعالى، فإِن من أحب الله

$$
\text { أنس به، واستغنى في حبه عما سواه. }
$$

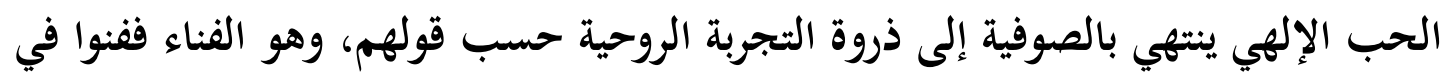

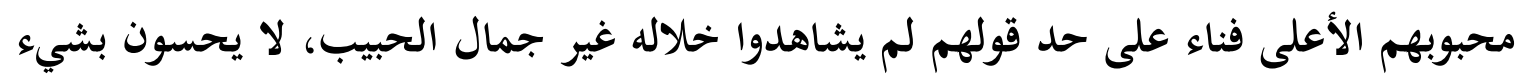

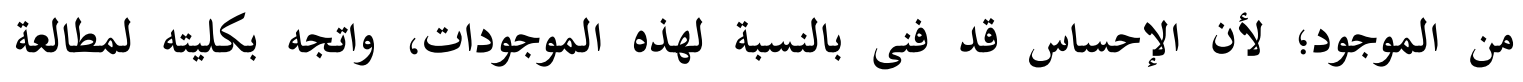

$$
\begin{aligned}
& \text { (1) الأصفهاني: حلية الأولياء، ج9، ص ب ع ب. }
\end{aligned}
$$

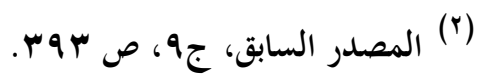

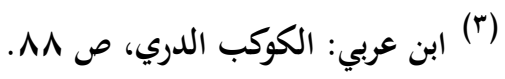

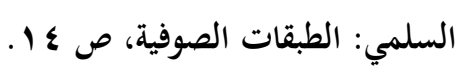


المحبوب، وبالفناء يفقد الصوفية عالم الناس ليعيشوا في عالم آخر هو عالم الجمال المطلق، والخير المطلق والحق المطلق، وفي عالمهم هذا ترفع الأستار عن الأسرار حسب ما يزعمون، وتتجلى لهم الحقائق حق اليقين وعين اليقين" (1) .

وذو النون المصري من أسبق الصوفية (r)، الذين تعمقوا في فهم معنى الفناء، وربطوا بينه وبين المحبة برباط وثيق، بيد أنه لم يورد لفظ الفناء صراحة في أقواله، ولكنه وصف حالات للصوفي في حديثه عن الذكر والمحبة والمعرفة هي أقرب إلى معنى الفناء، وذلك على زعم أن لفظة الفناء كانت شائعة ومتداولة في عصره خاصة عند معاصره أبي يزيد البسطامي. ولعل السبب في ذلك أن تصوف ذي النون أساسًا كان مثقيدًا بالكتاب والسنة، وليس فيهما لفظ الفناء، أو أن ذا النون كان أكثر دقة وحذرًا من غيره من الصوفية، باعتبار أن الفناء مزلة أقدام

الرجال أدى بالكثير منهم فيما بعد إلى القول بوحدة الوجود (ب) . ويربط ذو النون المحبة بالفناء عندما يصف المحبين لله بأنهم قد ملأت محبة الله صدورهم؛ لذلك لا يلتفتون لأي كلام صدر ممن حولهم من الناس، ولا يجدون لذة في شيء

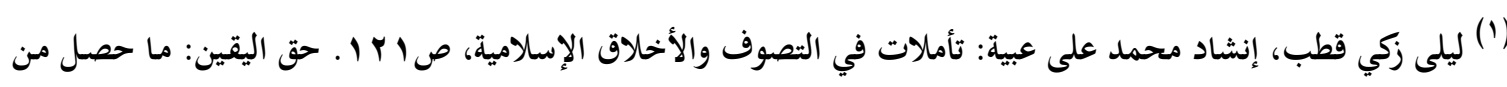

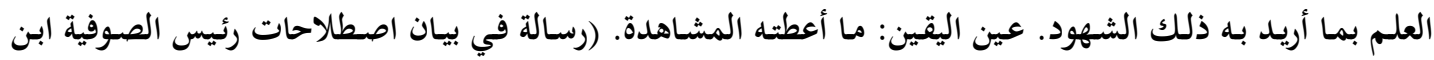

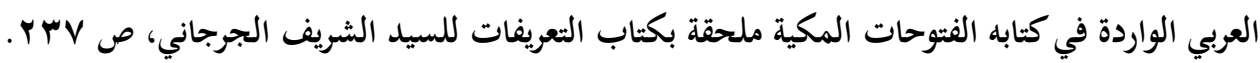
(r) كانت نظرية أوائل الصوفية في الفناء مستندة إلى فكرتهم في الإرادة الإلهية، وأن الله تعالى هو المريد في الحقيقة لكل شيء، فيجب أن يتخلى العبد عن إرادته، ويترك الأمر لصاحبه، وذلك بخحلاف نظرية الفناء المستندة إلى فكرة أن الله

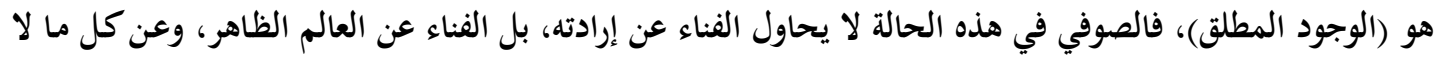
حقيقة له في ذاته، وهو ما يسمى بوحدة الوجود. (رينولد "أ" نيكولسون، في النصوف الإسلامي وتاريخه، ص بـ م 1)، (1) $\varepsilon$ (ץ) وحدة الوجود: أجمعوا على أن الأشياء موجودة في الخارج كما هو مذهب النظار غير أنهم قالوا هي موجودة بوجود

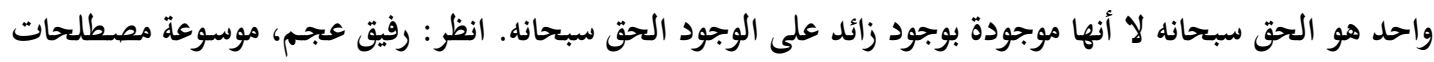


سوى الأنس بالله، ومحادثة الله عز وجل، يقول ذو النون عنهم: "قد ملأت محبة الله صدورهم،

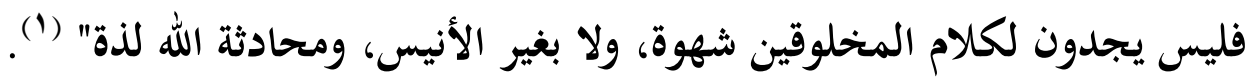

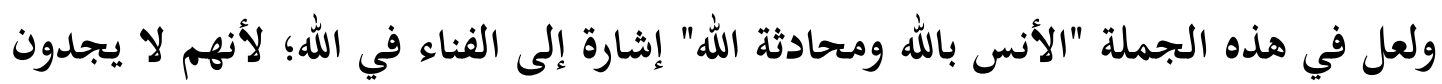
كلامًا إلا كلام الله، ولا أنيسًا إلا الله (“).

وكلام ذي النون عن الفناء الذي يرتبط بالمحبة يتضمن ثلاثة أنواع متميزة:

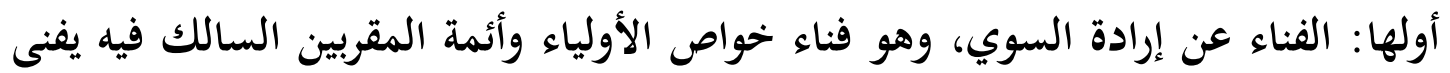

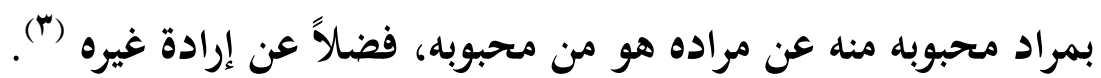

ويظهر ذلك المعنى في قول ذي النون: "من أعلام الحب في الله: بذل الشيء لصفاء

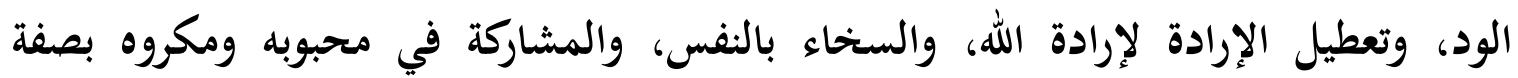

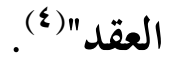

فقوله: "تعطيل الإرادة لإرادة الله" تعني الفناء عن إرادة السوي، بمعنى أن تفنى إرادة

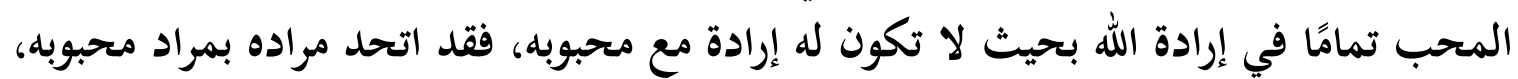
أعني: المراد الديني الأمري، لا المراد الكوني القدري، فصار المرادان واحدًا (0).

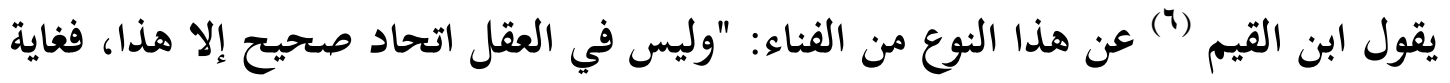

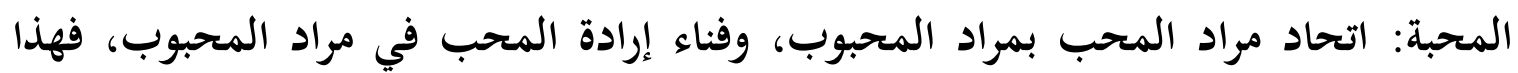

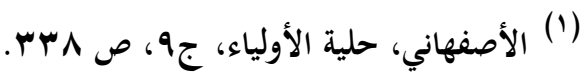

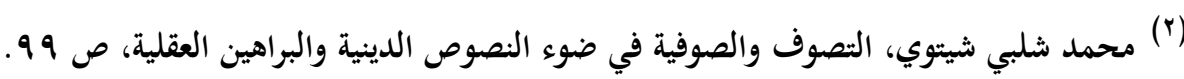

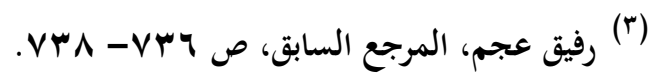

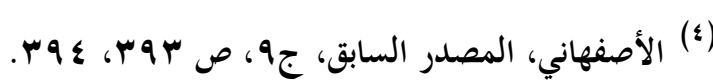

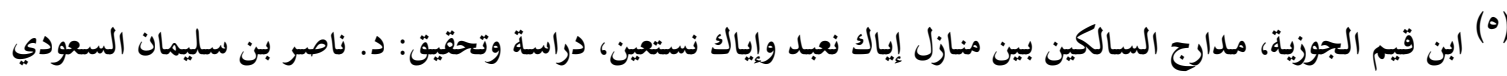

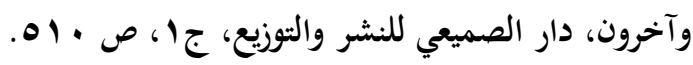

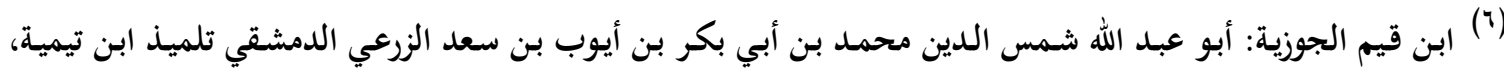

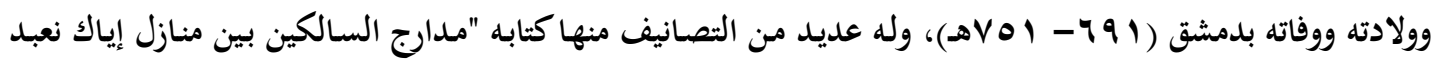
وإياك نستعين". (عبد المنعم الحفني: الموسوعة الصوفية، ص بآبآ). 
الاتحاد والفناء هو اتحاد خواص المحبين وفناؤهم، فنوا بعبادة محبوبهم عن عبادة ما سواه،

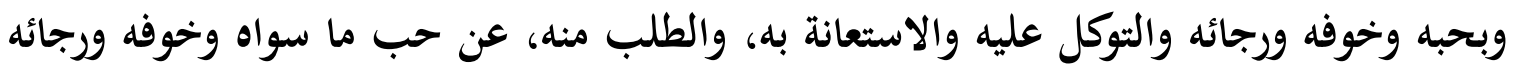

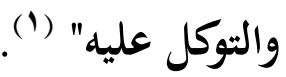

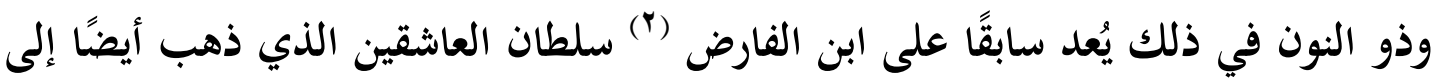

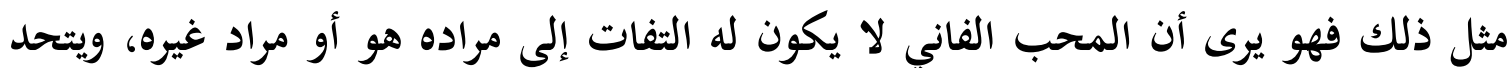

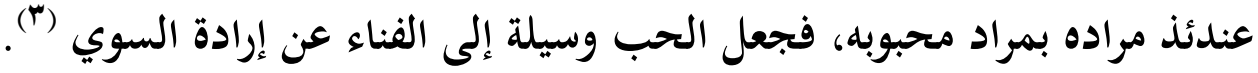

ويشير ابن الفارض إلى مثل هذا الفناء قائلاً:

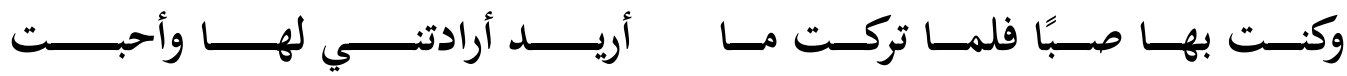

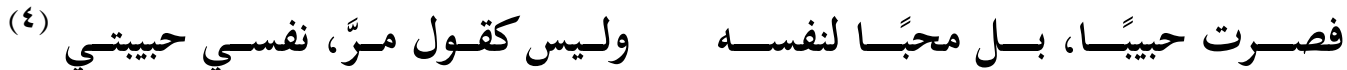

ويصير المحب أيضًا في هذه الحالة عند ابن الفارض راضيًا عن محبوبه تمام الرضا، مسلمًا

له قيادة، فيخاطب محبوبه قائلاً:

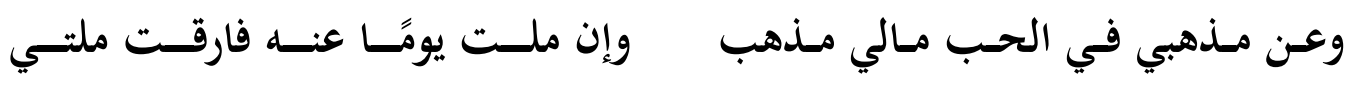

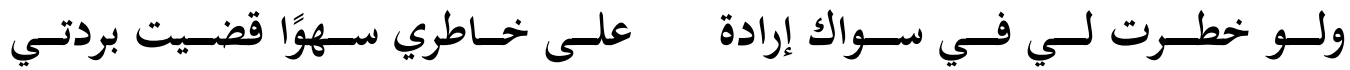

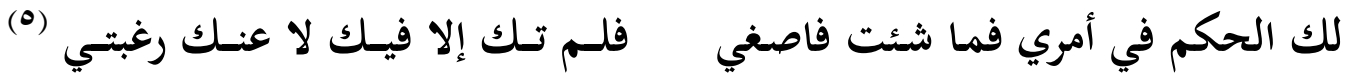

ومن الجدير بالذكر أن الفناء عن إرادة السوي عند ذي النون يجب أن يكون مقترنًا باحترام

الأوامر والنواهي الثرعية، وهو ما عبر عنه ذو النون بقوله: "السخاء بالنفس والمشاركة في

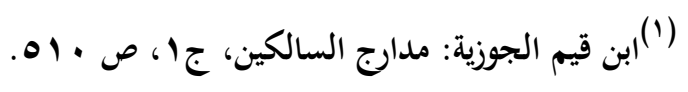

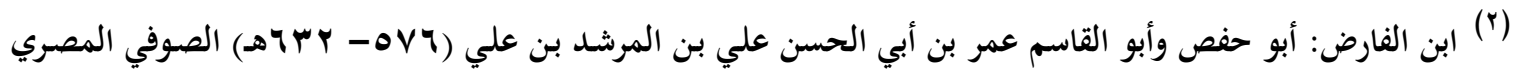

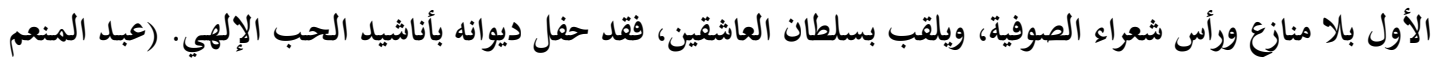

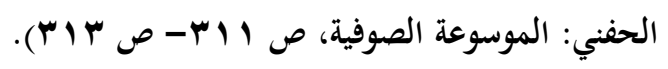

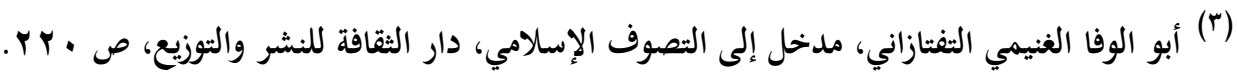

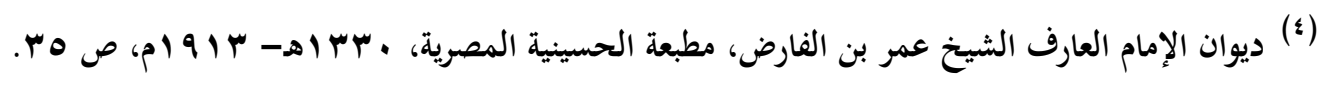

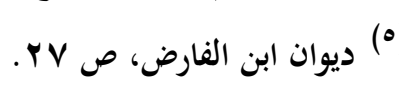


محبوبه ومكروهه بصفة العقد" (1). وهو يعني هنا التقرب إلى الله بالطاعات والمجاهدات، وقهر النفس، وتخليتها عن مذامها وعللها، وهو يؤكد ذلك عندما يقول: "أول الطريق إلى الله المحبة،

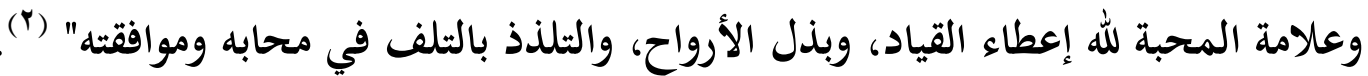
يقول ابن القيم: "ومن تحقيق هذا الفناء أن لا يحب إلا في الله، ولا يبغض إلا فيه، ولا يوالي إلا فيه، ولا يعادي إلا فيه، ولا يعطي إلا له، ولا يمنع إلا له، ولا يرجو إلا إياه، ولا

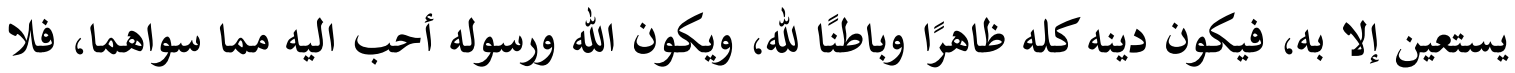
يواد من حاد الله ورسوله، ولو كان أقرب الخلق إليه، بل:

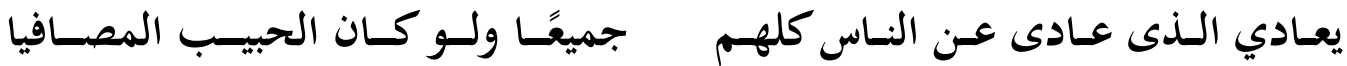
وحقيقة ذلك فناؤه عن هوى نفسه وحظوظها بمراضي ربه وحقوقه. والجامع لهذا كله:

تحقيق شهادة أن لا إله إلا الله علمًا ومعرفة وعملاً وحالاً وقصدًا" (ب). والثاني: من أنواع الفناء عند ذي النون الفناء عن شهود المحبة ذاتها بمعنى أن المحب يفنى عن المحبة نفسها، فلا يشعر بمحبته لحبيبه. وإلى هذا المعنى من المعاني يشير ذو النون عندما سئل: "ما المحبة الصافية التي لا كدرة فيها؟ فقال: حب الله الصافي الذي لا كدرة فيه: سقوط المحبة عن القلب والجوارح حتى لا يكون فيها المحبة، وتكون الأشياء بالله ولله، وذلك المحب لله" (؛). أما النوع الثالث: فهو الفناء عن شهود السوي (•)، وهو فناء يستشعر فيه الصوفي فناء ذاته في ذات المحبوب، وإلى ذلك يشير ذو النون بقوله:

$$
\begin{aligned}
& \text { (1) (الأصفهاني، حلية الأولياء، ج9، ص ع ج". }
\end{aligned}
$$

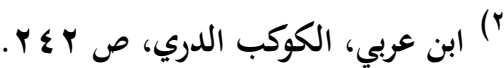

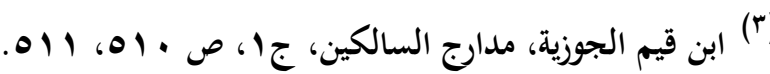

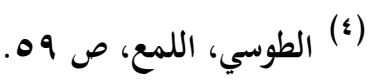

(•) الفناء عن شهود السوى: هو الفناء الذي يشير إليه أكثر الصوفية، فحقيقته فناء ما سوى الله عن شهودهم، وحسهم فهو

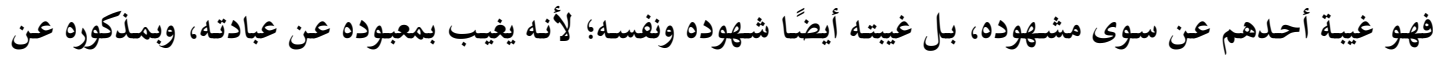

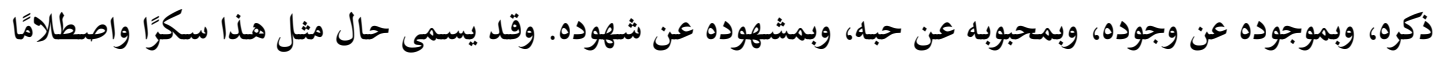

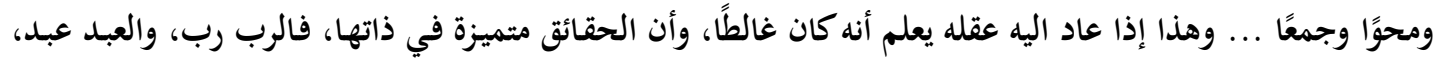



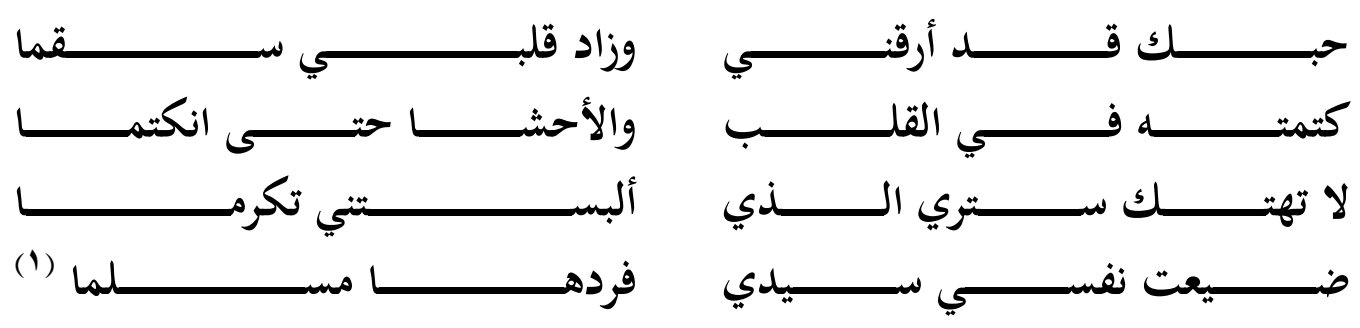

ويقصد ذو النون بضياع النفس هنا شعور المحب بفناء ذاته في ذات محبوبه.

يذكر يوسف بن الحسين (ז) أنه كان عند ذي النون "فجاءه رجل وقال له: رأيت أبا يزيد البسطامي، فقيل له: أنت أبو يزيد؟ فقال: ومن أبو يزيد؟! يا ليتني رأيت أبا يزيد، فبكى ذو لهو

النون وقال: إن أخي أبا يزيد فقد نفسه في حب الله تعالى، فصار يطلبها مع الطالبين لها" (َّ). ومن عبارات ذي النون التي تدل على هذا النوع من الفناء قوله: "من ذكر الله على حقيقه،

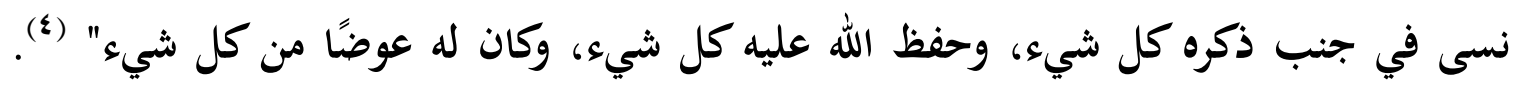
وقوله، عندما سئل عن الذكر، فقال: غيبة الذاكر عن الذكر، ثم أنشد: ولئ

والخالق بائن عن المخلوقات، ليس في المخلوقات شيء من ذاته، ولا في ذاته شيء من مخلوقاته. (رفيق العجم،

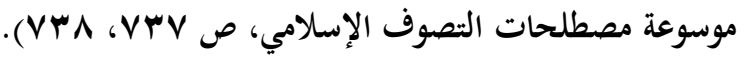

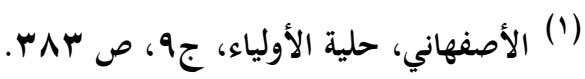

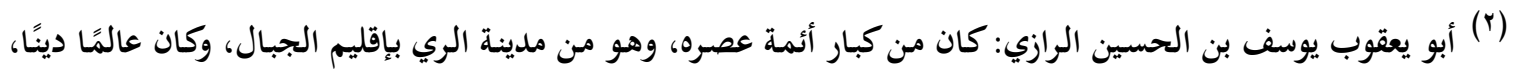

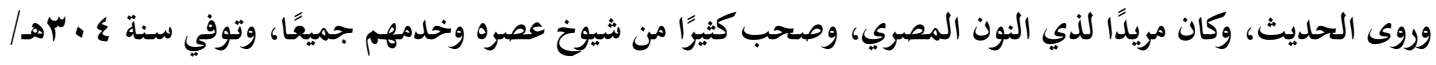

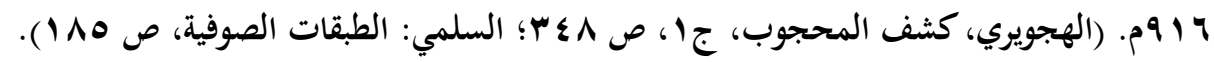

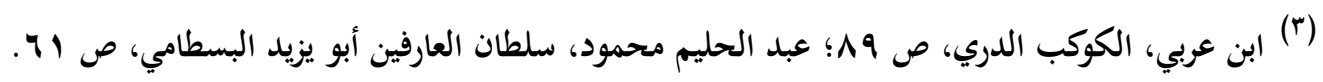

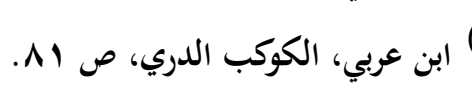




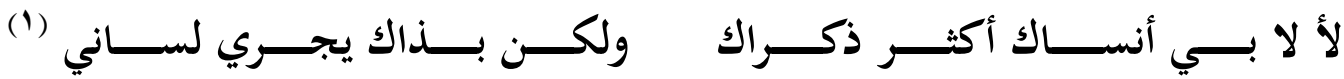

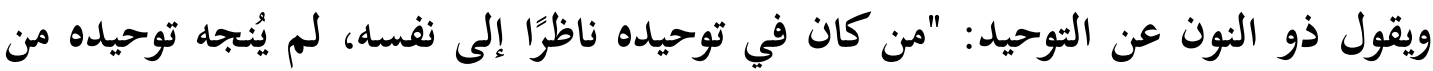

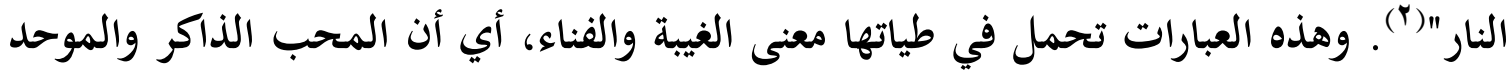
يجب أن يفقد نفسه تمامًا في ذكره وتوحيده، بمعنى أن يغيب بشعوره وحبه، ويفنى في الله فناءً

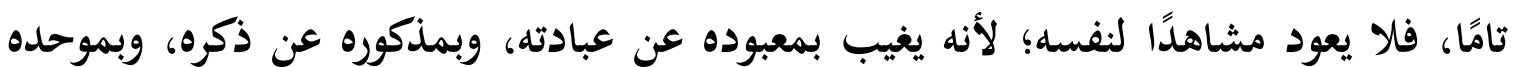
عن توحيده، وبمشهوده عن شهوده.

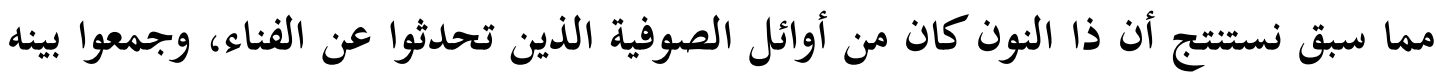

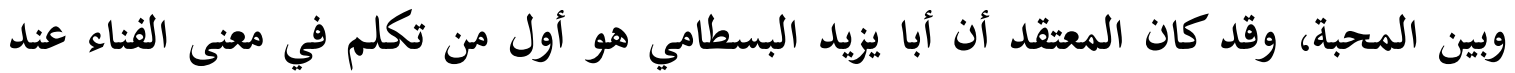

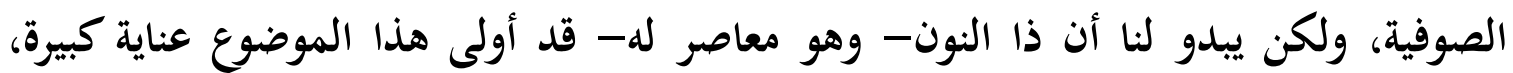
وذلك حين ربط بين الحب والفناء برباط وثيق كما رأينا. ونستنتج كذلك أن صوفية الحب الإلهي المتأخرين- أمثال ابن الفارض- قد تد تأثروا بذي النون في حديثه عن الحب الإلهي والفناء.

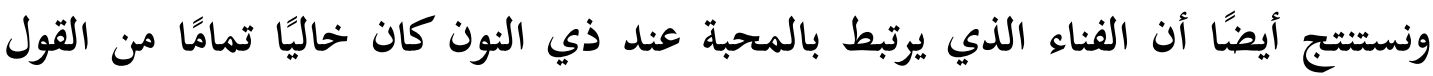

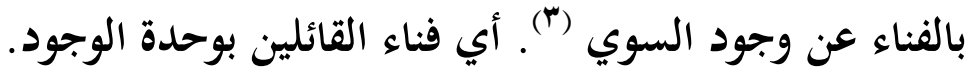
يقول الدكتور أبو العلا عفيفي في ذلك: "وقد يقال إن في بعض ما أثر عنه (ذو النون) من

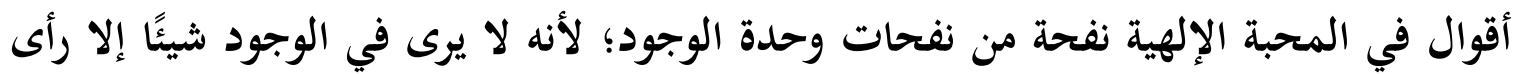

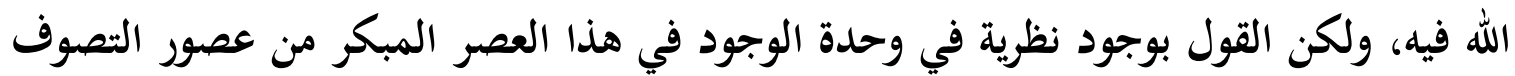

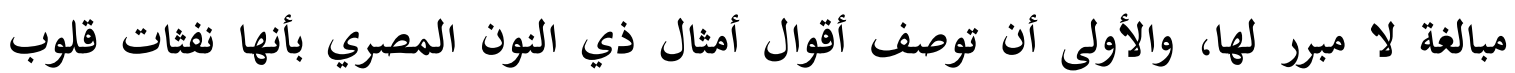

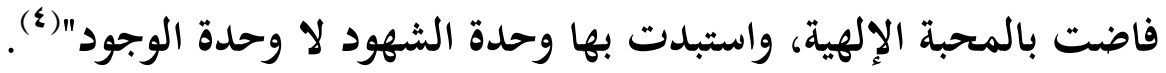

$$
\text { (') (1) ابن عربي، المصدر السابق، نفس الصفحة. }
$$

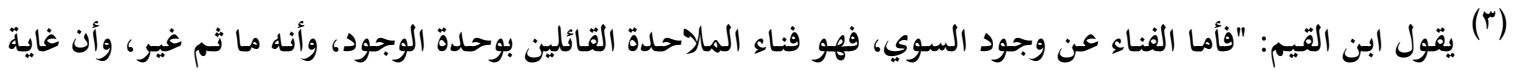

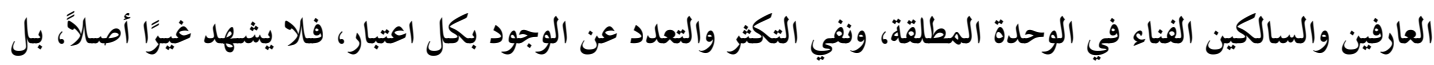

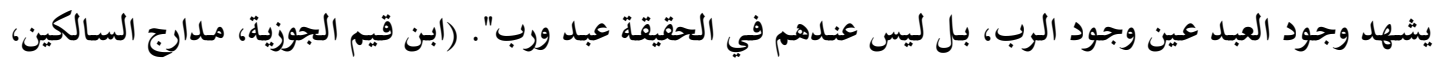

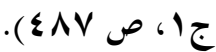

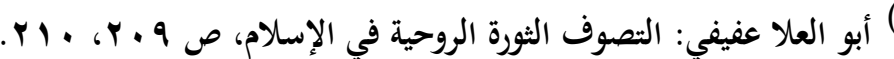


خامساً : المحبة والمعرفة: أحل ذو النون المصري المعرفة منزلة هامة في مذهبه، فقد رأى أن غاية الحياة الصوفية الوصول إلى مقام المعرفة الذي تتجلى فيه الحقائق، فيدركها الصوفي إدراكًا ذوقيًا لا أثر فيه للعقل، ولا للرؤية، وذلك لا يكون إلا لخاصة أهل الله الذين يرونه بأعين بصائرهم (1). والمعرفة عند ذي النون على ضروب ثلاثة: الأول: معرفة عامة المؤمنين، والثاني: معرفة المتكلمين والحكماء، والثالث: معرفة خواص الأولياء المقربين الذين يعرفون الله بقلوبهم. يقول الدكتور محمد مصطفى حلمي: "وليس من شك في أن هذا الضرب الثالث من المعرفة هو عند ذي النون أرقى وأسمى ضروبها جميعًا. وذلك لأنها تتخذ موضوعها من الذات الإلهية، وما لهذه الذات من صفات الوحدانية، ومن لا تحصل عن طريق الكسب والتعلم والتصور والاستدلال، وإنما هي إلهام، ونفث في الروع، ونور يقذفه الله في سر العبد، فيعرف العبد الله معرفة مباشرة لا واسطة فيها، ويقينية لا شك يعتريها" (ب). وقد أشار ذو النون إلى ذلك حين سُئل: "بم عرفت ربك؟ قال: عرفت ربي بربي، ولولا ربي لما عرفت ربي" ("ّ). وقد سُئل أيضًا ذو النون: بِّمَ عرف العارفون ربهم؟ فقال ما نصه: "إن كان بشيء فيقطع، والإشراف منهم على اليأس مع التمسك منهم بالأحوال التي أقامهم عليها، وبذل المجهود من أنفسهم، ثم إنهم ما وصلوا بعد إلى الله إلا بالله" (๕.). وأهل المعرفة عند ذي النون محجوبون عن غيرهم من الناس، رعايةً من الله لهم؛ نظرًا لعلو مكانتهم مع عدم ظهورهم بالادعاء بين الناس، وفي هذا المعنى يقول: "سبحان من حجب أهل المعرفة عن جميع خلقه، حجبهم عن أبناء الدنيا بأستار الآخرة، وعن أبناء الآخرة بأستار

$$
\text { (1) (1) رينولد. أ. نيكولسون، في التصوف الإسلامي وتاريخه، ص ع ع. (1) }
$$

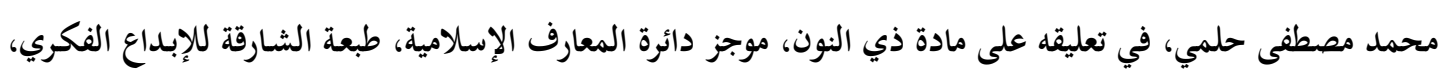

$$
\begin{aligned}
& \text { الجزء السادس عشر. }
\end{aligned}
$$

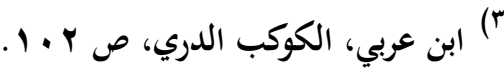

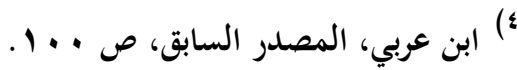

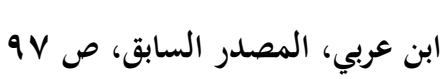


وفي حقيقة المعرفة يقول ذو النون: "حقيقة المعرفة إطلاع الحق على الأسرار بمواصلة لطايف الأنوار، وأنشد في المعنى شعرًا:

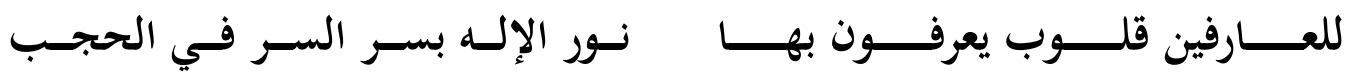

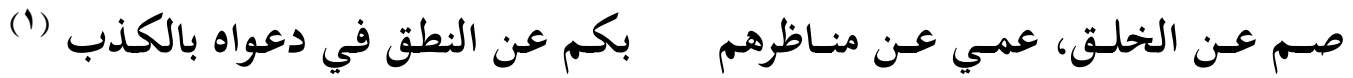

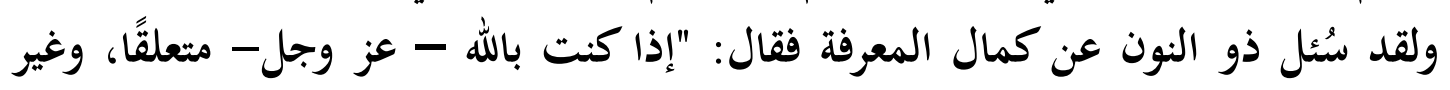

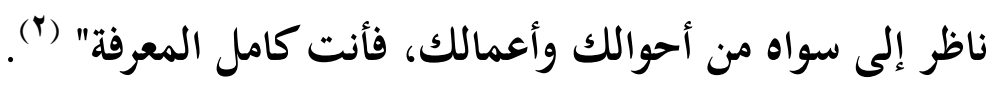
وأما عن علاقة المحبة بالمعرفة، فيرى ذو النون أن المحبة هي وسيلة الصوفي إلى المعرفة بالله ذوقًا (المعرفة الكشفية)، ولا يصل إلى نهاية الطريق إلا من لازمتله المحتبة. وهذا الذي جعل ذو النون يصف الحب لله بأنه "أول الطريق إلى الله" ("). ويوضح ذو النون طريق أهل المحبة للوصول إلى المعرفة فيقول:

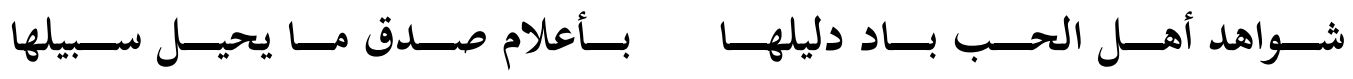

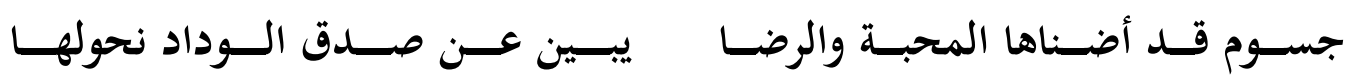

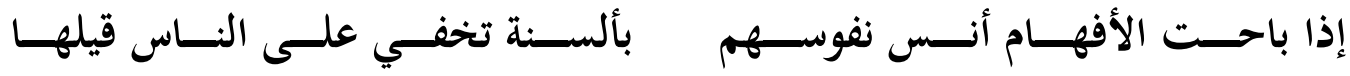

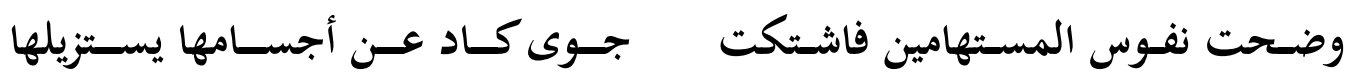

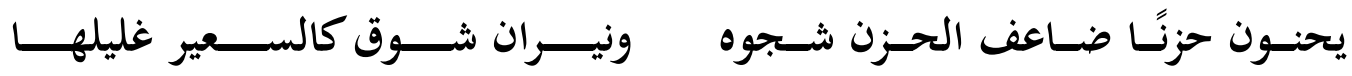

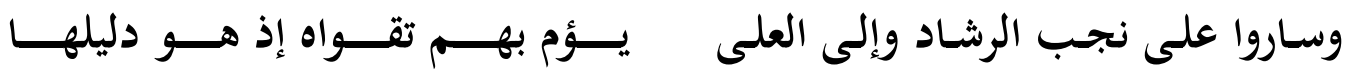

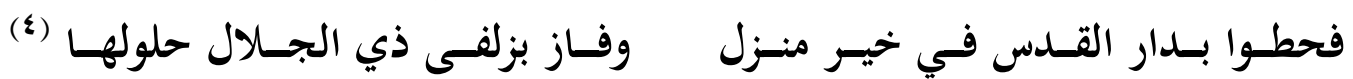

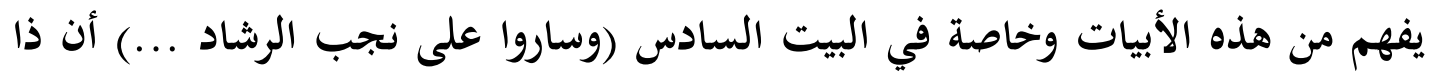

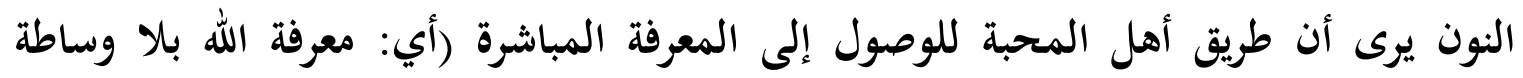

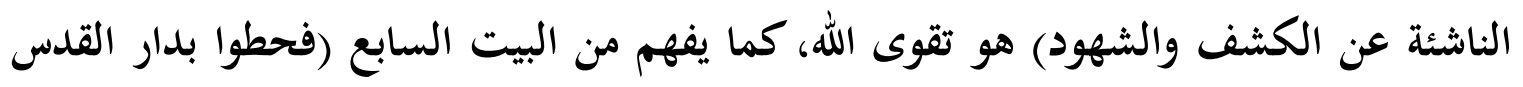

$$
\begin{aligned}
& \text { (1) (1) (1) عربي، الكوكب الدري، ص } 9 \text { (1). }
\end{aligned}
$$

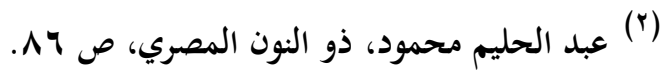

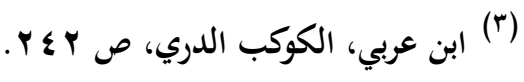

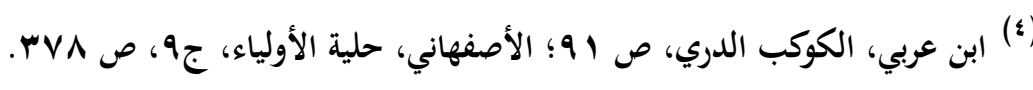


... أن قلوب أهل المحبة قد ارتقت إلى عالم الشهادة، وتحققت بالمعرفة الكثفية الذوقية بالله، وهي غاية المحبة والرضا الذي عبر عنها بقوله:

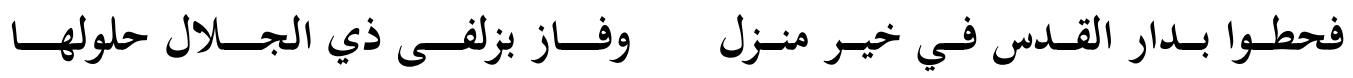

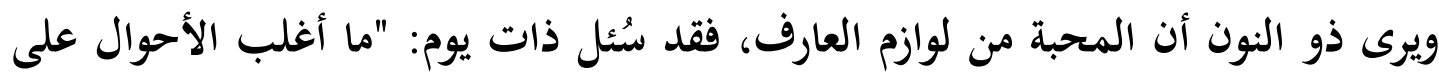

العارف؟ قال: حبه، والحب فيه، ونشر الآلاء، وهي الأحوال التي لا تفارقه" (1).

وقد ربط ذو النون بين المحبة والمعرفة في كثير من أقواله، نذكرها فيما يلي:

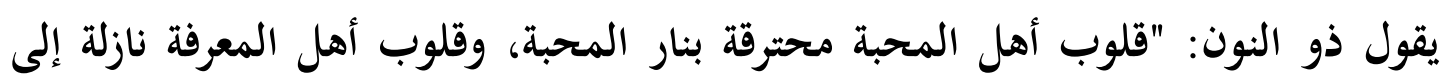

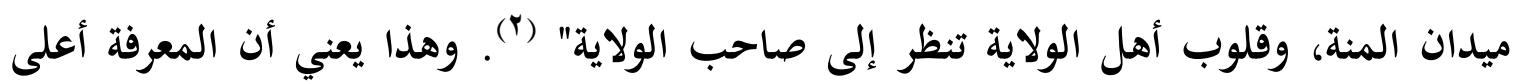
درجة من المحبة من حيث درجة القرب من الله، وتلقي مننه تعالى. ومن أقوال ذي النون عن أهل المحبة والمعرفة "أن لله عبادًا على الأرائك يسمعون كلام الله إذا كلم المحبين في المشهد الأعلى؛ لأنهم عبدوه سرًا، فأوصل إلى قلوبهم طرائف البر لهر

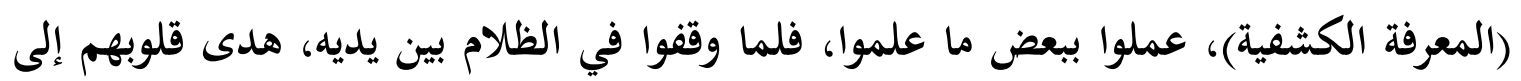
ما يعلمون، فحسرت ألبابهم لمعرفة الوقوف بين يديه" (َّ). ويقول ذو النون أيضًا: "إنك إذا أطعته، أفادك حبه، وأدناك إلى قربه، وإذا أدناك إلى قربه، أسبل عليك حجاب هيبته، ثم لذذك بمناجاته، وآنسك بذكره، فإذا آنسك بذكره، أقعدك على موائد سره (أي أعطاك العلم اللدني)، ثم روحك، وفضلك، وحكمك، وأيدك، ثم أوصلك بوصاله إلى موصله (وهو المعرفة الكشفية)، فاتصلت بلا وصل، ووصلت وصلت بلا فلا فصل، وهذا

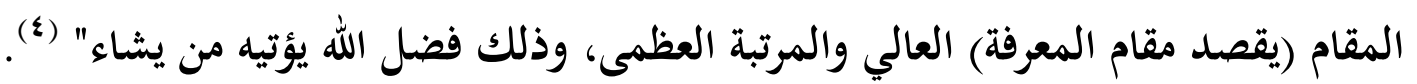

$$
\begin{aligned}
& \text { (1) الأصفهاني، حلية الأولياء، ج9، ص ع ع. }
\end{aligned}
$$

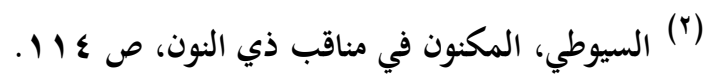

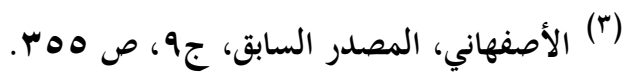

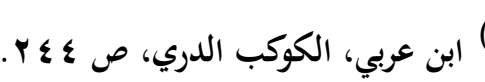




$$
\text { كما يقول ذو النون في أحد أدعيته: }
$$

"إلهي لا تترك بيني وبين أقصى مرادك حجابًا إلا هتكته، ولا حاجزًا إلا رفعته، ولا وعرًا إلا سهلته، ولا بابًا إلا فتحته، حتى يقيم قلبي بين ضياء معرفتك، وتذيقني طعم محبتك، فيا من

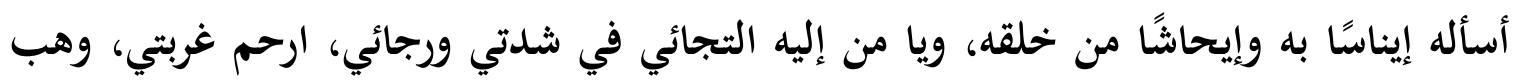

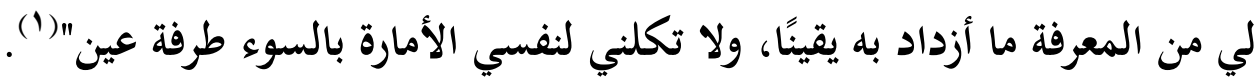
فهو هنا يدعو ربه أن يهتك الحجب، ويرفع الحواجز، وييسر الوعر من الطيق، ويفتح له له باب الثهود بحيث ينغمس قلبه في ضياء "المعرفة"، ويتذوق طعم المحبة.

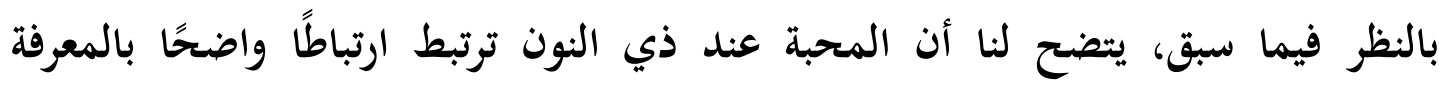

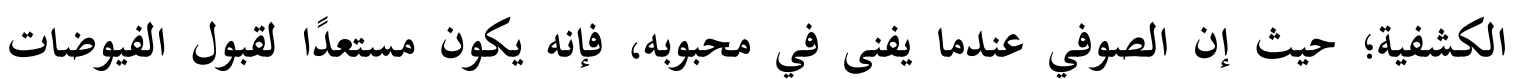

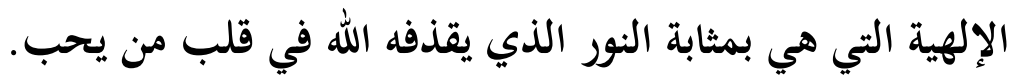




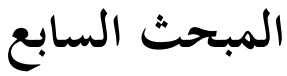

\section{نماذج من مشاهدات ذي النون للمحبين الإلهيين}

طاف ذو النون في البلاد والسواحل والجبال، فقابل كثيرًا من العابدين المجتهلين

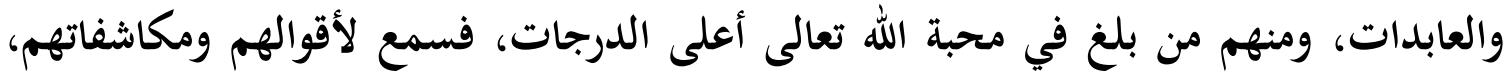

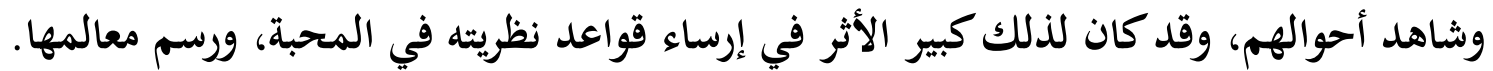

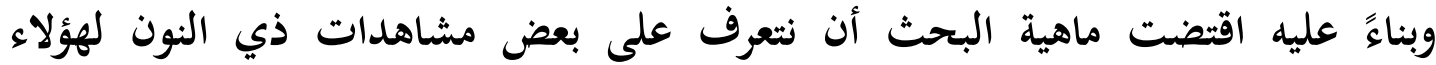
المحبين والمحبات لله وفي الله، وحكايته عنهم، ومشاهداته للهم.

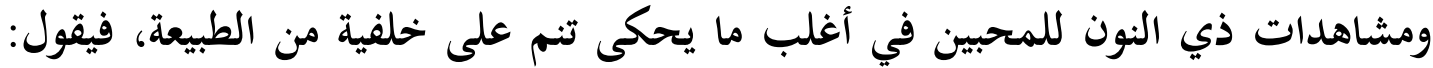

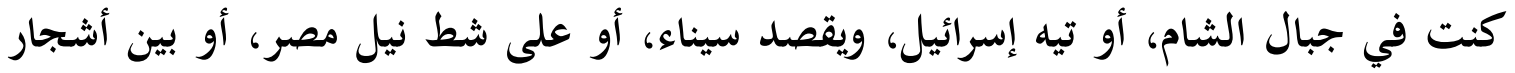

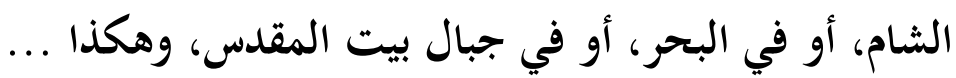

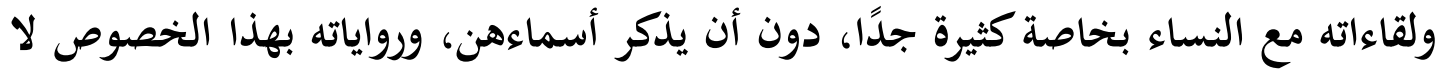

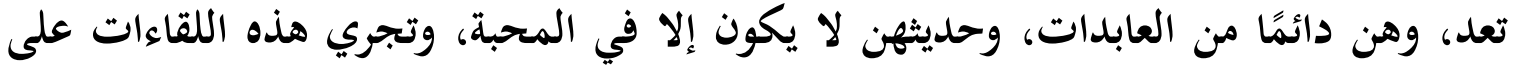

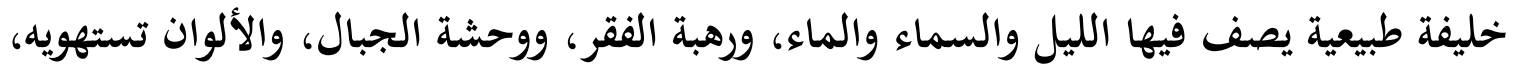

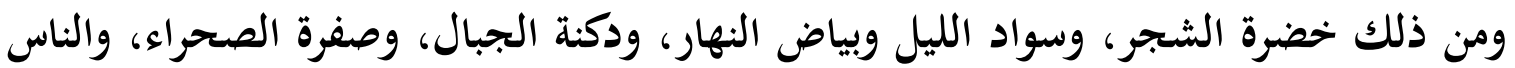
عنده سود البشرة أو بيض، والأصوات يلونها الحزن والشجن، والقلوب التهن تحرقها اللوعة، ودائمة التهائ الأنين (1)

$$
\begin{aligned}
& \text { ومن مشاهدات ذي النون للمحبين ما يلي: } \\
& \text { 1-في شوارع مصر: (وجه حيبك يهدي الحيارى): }
\end{aligned}
$$

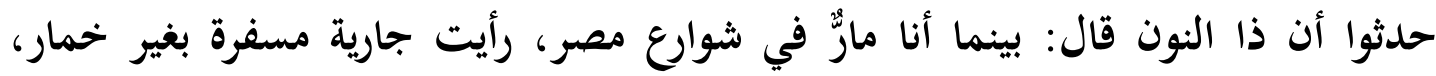

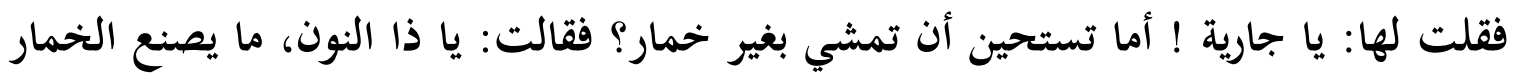

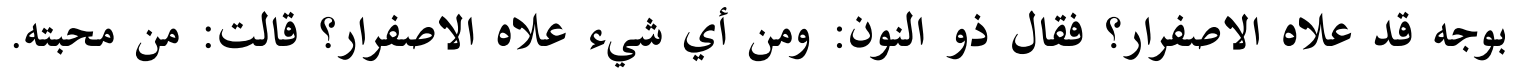

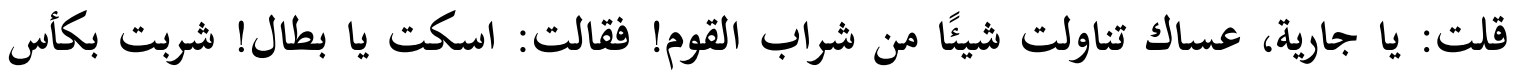

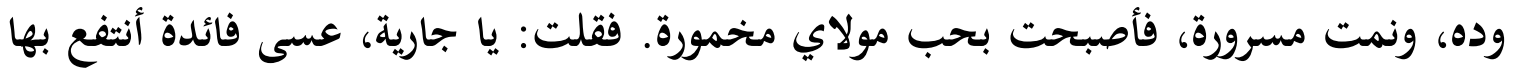

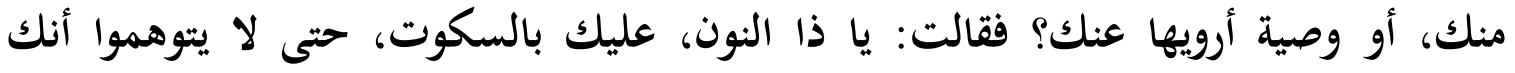

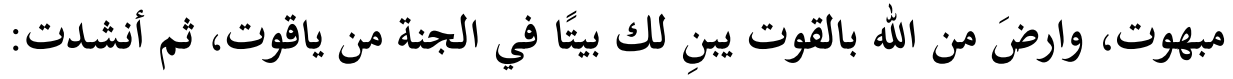

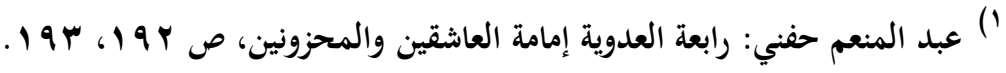




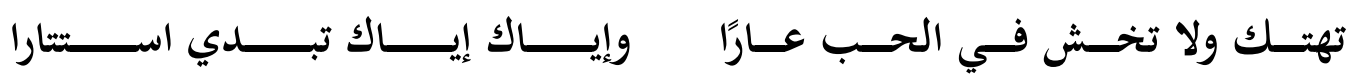

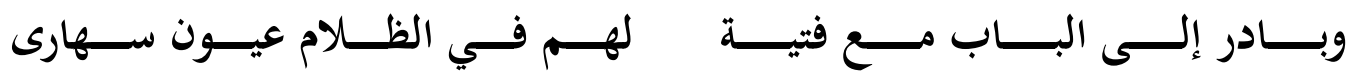

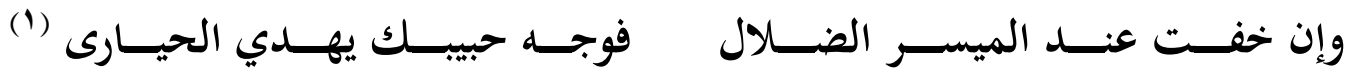

في هذه القصة نجد معنى من معاني المحبة عند ذي النون، وهو أن المحب يجب عليه

ألا يتحدث عن المحبة، أو يبوح بها لمن لا يعرف من المحبة غير معناها الحسي.

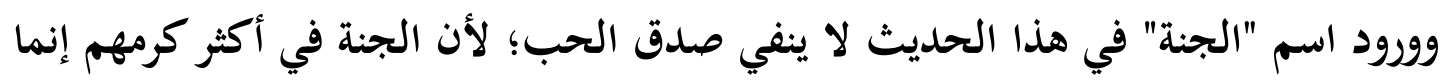
هي رمز بمعن الرضوان في الحب، والصوفية عمومًا يجردون الحب من الصفة النفعية، فيجعلونه

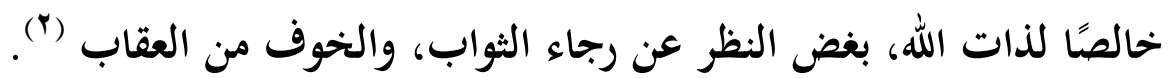

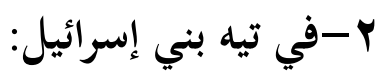

وعن محمد بن الحسين المصري قال: سمعت ذا النون يقول: بينما أسير في تيه بني

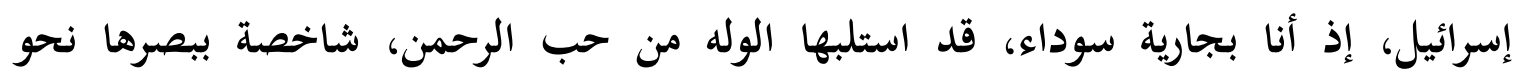

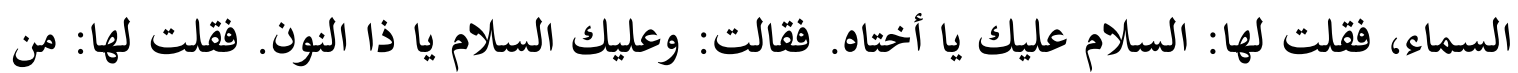
أين عرفتيني يا جارية؟ فقالت: يا بطال، إن الله عز وجل خلق الأرواح قبل الأجساد بألفي عام،

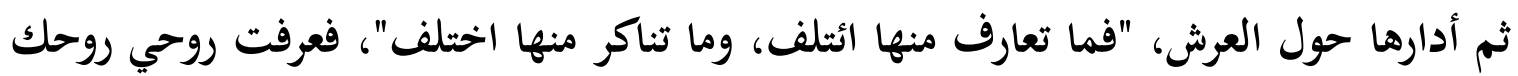
في ذلك الجولان حول عرش الرحمن. فقلت لها: إني لأراك كليمة، علميني شيئًا مما علمك روك الله. فقالت: يا أبا الفيض، ضع على جوارحك ميزان القسط؛ حتى يذوب كل مال ما كان لغير الله، ويبقى القلب مصفى، ليس فيه غير الرب عز وجل، فعند ذلك يقيمك على الباب، ويوليك

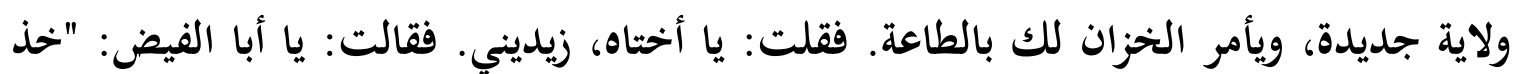

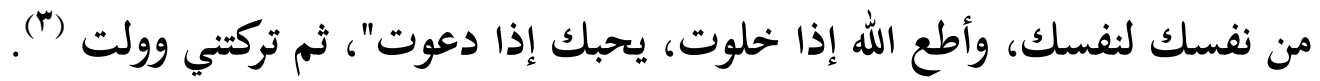

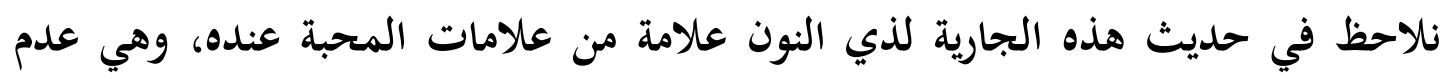
الذل لغير الله، وعدم طلب الحاجة من غير الله تعالى، وهذا إن دل فإنما يدل على ثأثر ذي مي تصدي النون بأحوال ومكاشفات المحبين والمحبات لله تعالى.

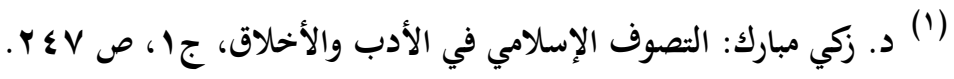

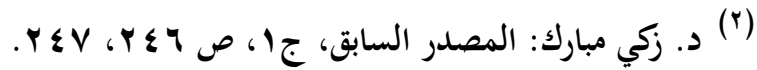

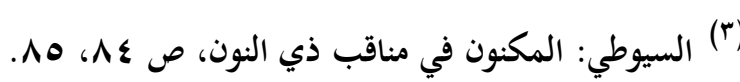




$$
\text { ب-في تيه بني إسرائيل: أحبك حبين: }
$$

حدثنا عثمان بن محمد بن عثمان، ثنا محمد بن أحمد الواعظ، ثنا العباس بن يوسف الشكلي، ثنا سعيد بن عثمان، قال: كنت مع ذي النون في تيه بني إسرائيل، فبينما نحن نسير، إذا بشخص قد أقبل، فقلت: أستاذ، شخص؟ فقال لي: انظر، فإنه لا يضع قدمه في هذا المكان إلا صديق. فنظرت فإذا امرأة، فقلت: إنها امرأة. فقال: صديقة ورب الكعبة. فابتدر إليها، وسلم عليها، فردت السلام، ثم قالت: ما للرجل ومخاطبة النساء؟ فقال لها: أني أخوك ذا النون، ولست من أهل التهم. فقالت: مرحبًا، حياك الله بالسلام. فقال لها: ما حملك على تهلى الدخول إلى هذا الموضع؟ فقالت: آية في كتاب الله تعالى: "ألم تكن أرض الله واسعة فتهاجروا

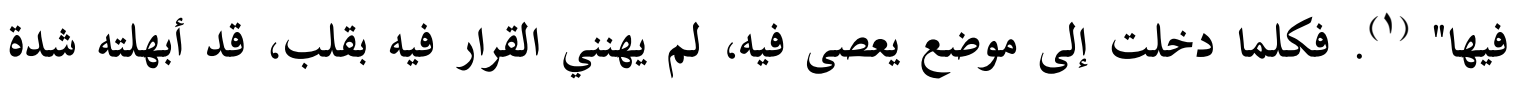

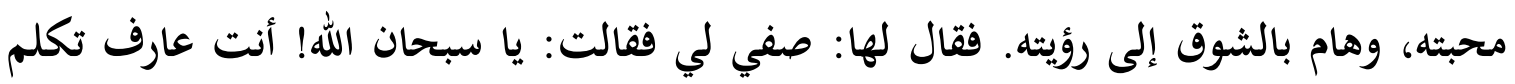
بلسان المعرفة تسألني؟ فقال: يحق للسائل الجواب، فقالت: نعم، المحبة عندي لها أول وآخر، فأولها لهج القلب بذكر المحبوب، والحزن الدائم، والتشوق اللازم، فإذا صاروا إلى لى له أعلاها شغلهم وجدان الخلوات عن كثير من أعمال الصالحات. ثم أخذت في الزفير والشهيق، وأنشأت تقول:

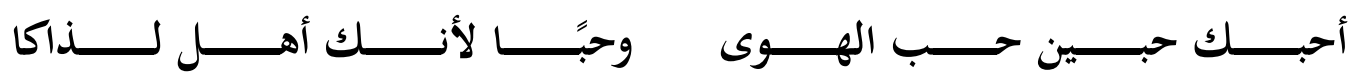

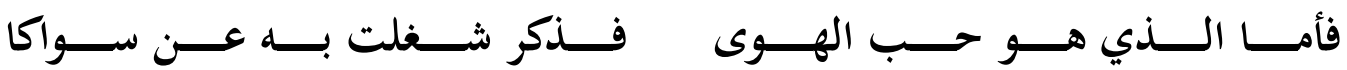

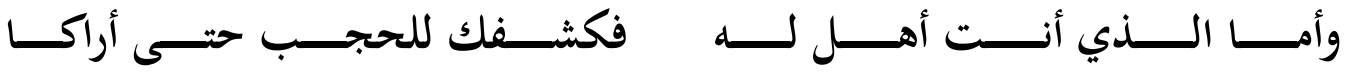

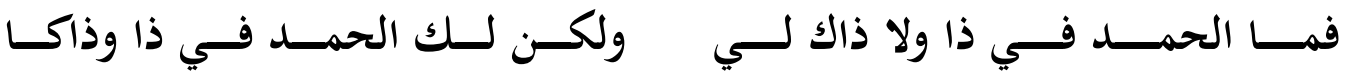
ثم شهقت شهقة، فإذا هي قد فارقت الدنيا (َ) وفي هذه الرواية لم يذكر ذو النون أيضًا اسم هذه المرأة العابدة العاشقة، وإنما نقل عنها أبياتًا في تقسيم الحب إلى حبين: حب الهوى، وحب خليق بذات الذات الله وحده، وإذا عرفنا أن هذه الأبيات قد اشتهر نسبتها إلى رابعة العدوية هنا نتساءل: هل التقى ذو النون ورابعة؟ لقد

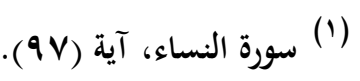

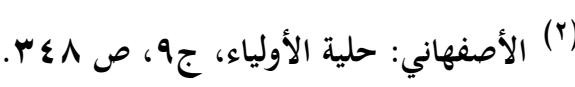


اختلفت آراء بعض العلماء والباحثين حول هذا اللقاء بين مثبت ونافٍ، وكان لكل رأي أدلته التي يستند عليها في تدعيم رأيه (1)- وهذا ليس موضوع البحث- فقد ذكر الدكتور محمد مصطفى حلمي أنه "على الرغم من أن كتب التراجم والطبقات قد تضاربت في إثبات الصلة بين ذي النون ورابعة ونفيها، فإننا لا نستطيع مع ذلك أن ننكر ما بين مذهبيهما في الحب الإلهي واستعمالهما للألفاظ الدالة عليه، والمعبرة عنه من أوجه الشبه" (ז). ع-في جبال بيت المقدس: إن المحب هو الصبور:

حدثنا أبو الحسن محمد بن محمد ثنا أحمد بن عيسى الوشاء قال: سمعت أبا عثمان أبمان

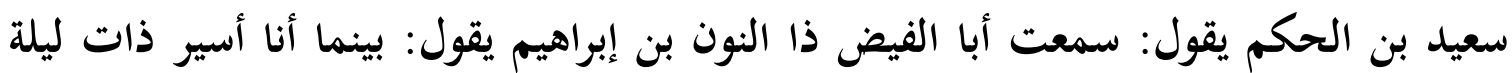

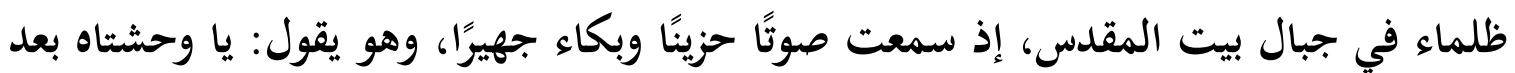

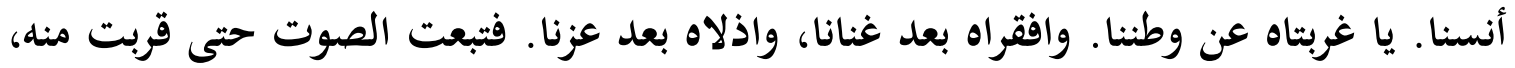

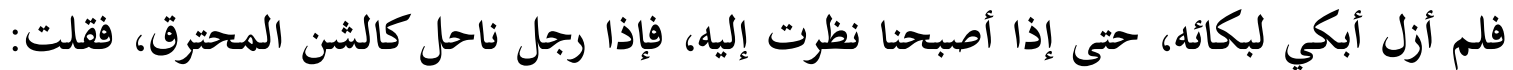

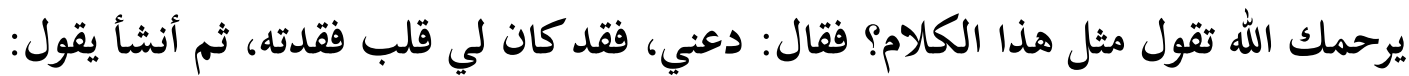

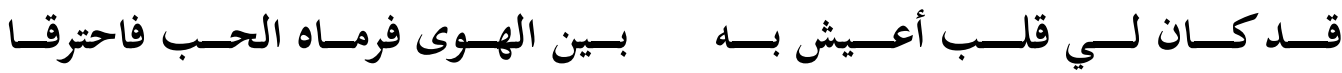
فقلت له:

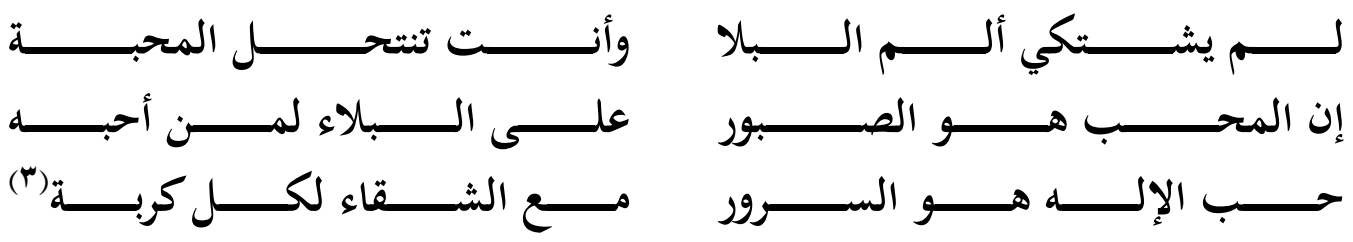
وفي هذه القصة يؤكد ذو النون على معنى من معاني المحبة، وهو صبر المحب على بلاء الحبيب، فالمحب هو الذي لا يشتكي مهما أصابه في حبه لحبيبه، فهو دائمًا يشعر بالسعادة

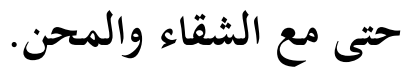
هذا القليل من الكثير من لقاءات ومشاهدات ذي النون للمحبين والمحبات، واكتفيت بهذا القدر لعدم الإطالة.

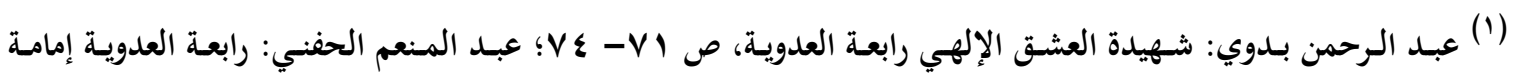

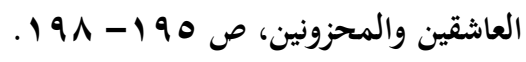
(r) محمد مصطفى حلمي: موجز دائرة المعارف الإسلامية، الجزء السادس عشر، مادة ذي النون.

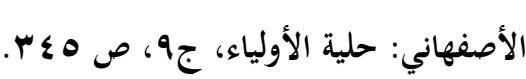


وضح من خلال صفحات البحث "المحبة الإلهية عند ذي النون المصري" أنه درس منذ

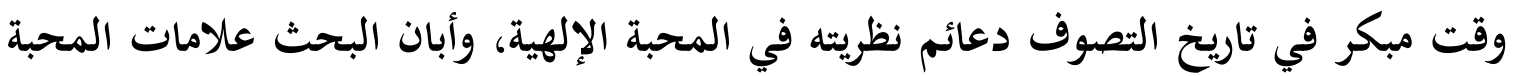

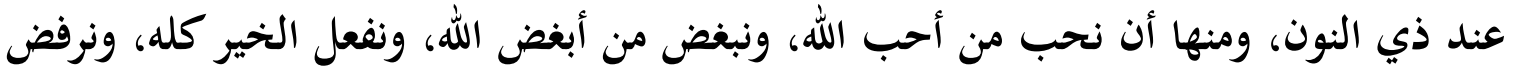

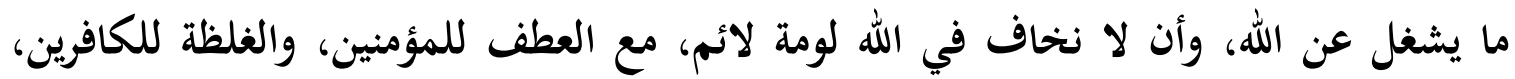

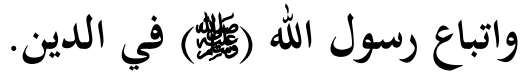
كما أبان البحث صفات المحبين وطبقاتهم عند ذي النون، كصفاء القلب، وأنهم مشتاقون

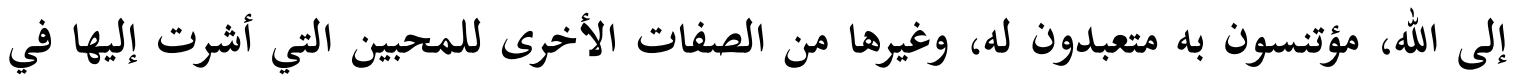

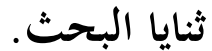
كذلك وضح من خلال البحث أن ذا النون من أوائل الصوفية الذين يستعملون عادةً لغة

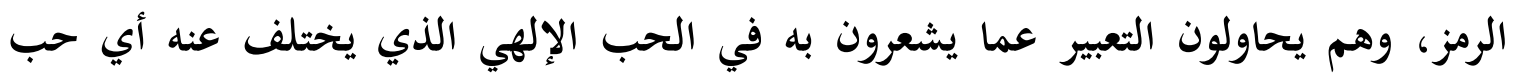

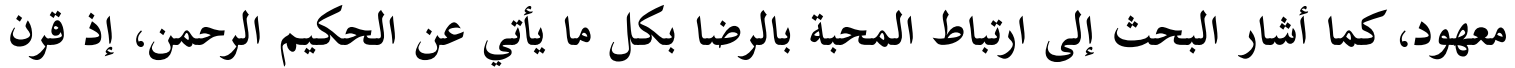

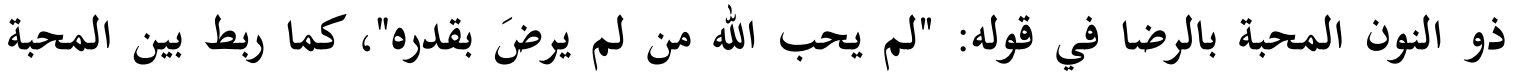
والشوق؛ إذ يرى أن الشوق أعلى الدرجات والمقامات. كما أبان البحث أيضًا علاقة المحبة بالثوق عند الثند ذي النوات النون، فهي علاقة التلازم، كذلك أوضح أن من أخص لوازم المحبة هو الأنس بالله.

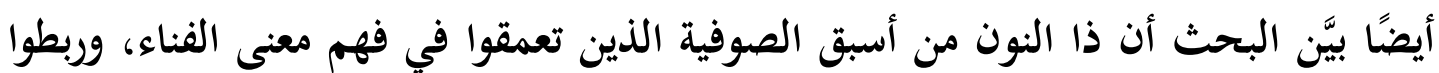

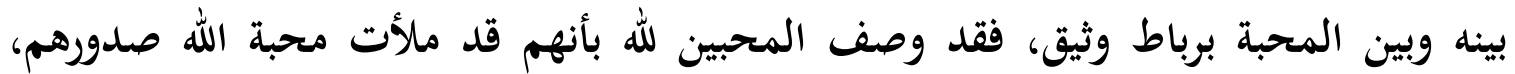

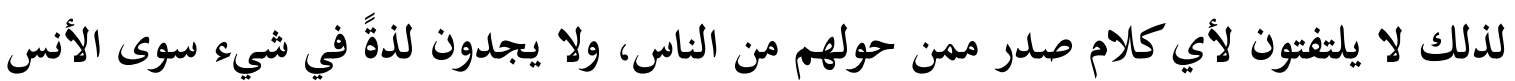
بالله.

وأظهر البحث علاقة المحبة بالمعرفة عند ذي النون، إذ يرى أن المحبة هي وسيلة

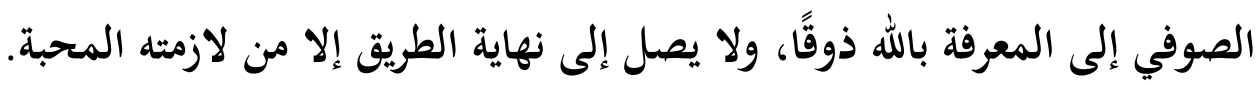

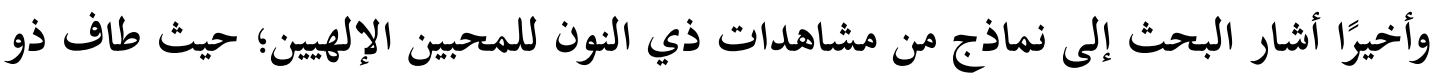

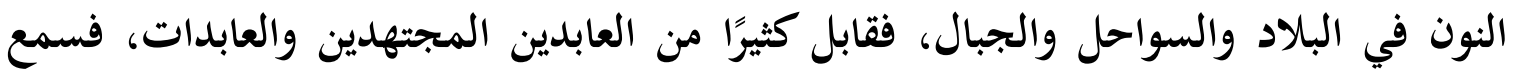
لأقوالهم ومكاشفاتهم، وشاهد أحوالهم، وقد كان لذلك عظيم الأثر في إرساء قواعد نظريته في

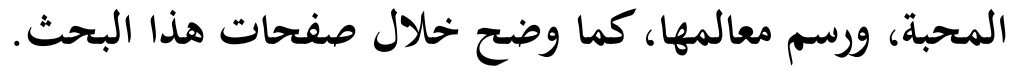


المصادر والمراجع

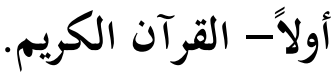

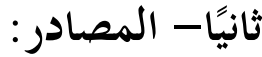

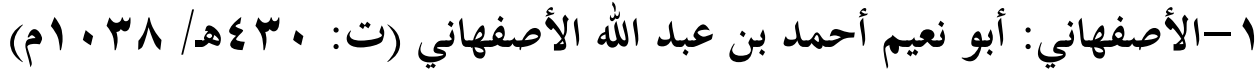

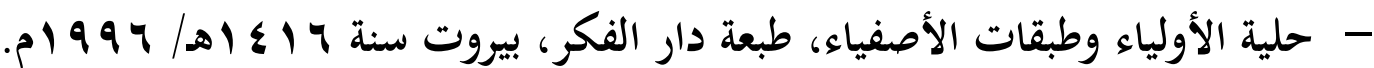

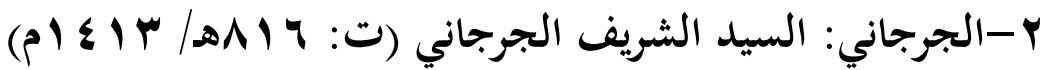

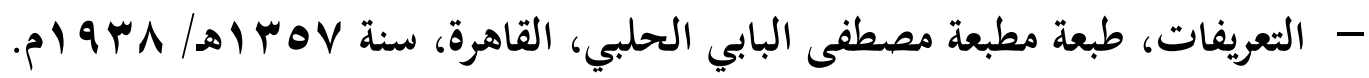

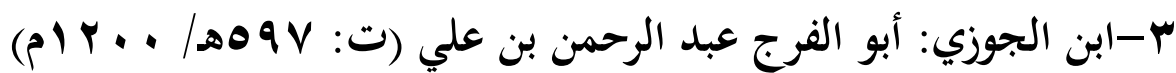

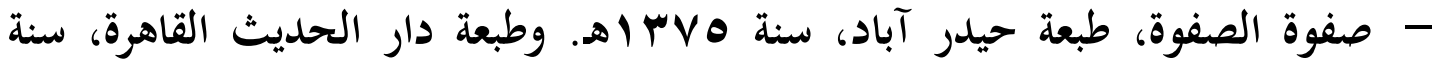

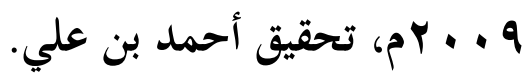

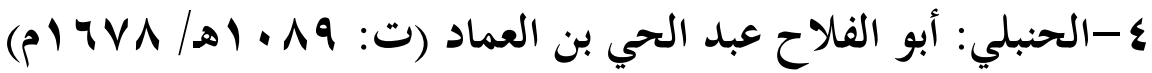

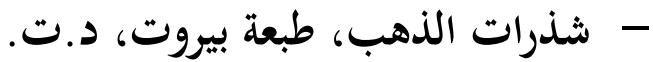

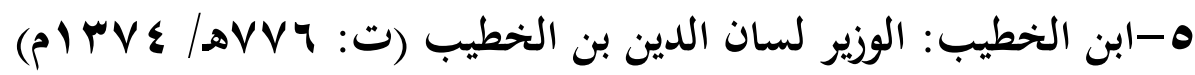

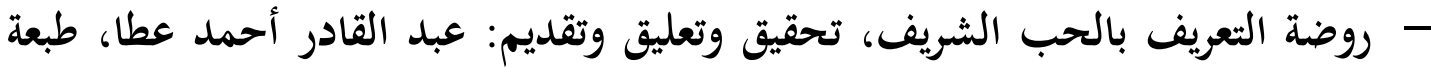

$$
\text { دار الفكر العربي، د.ت. }
$$

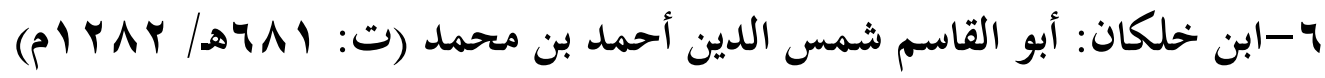

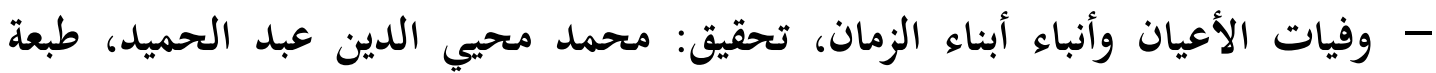

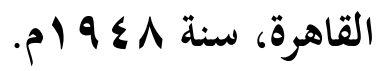

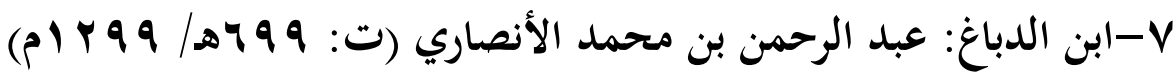

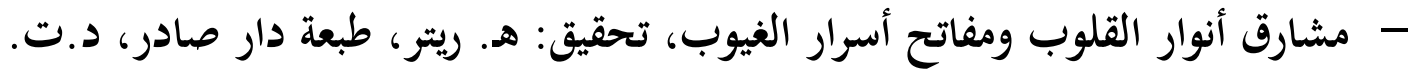

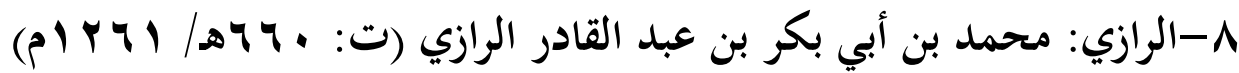

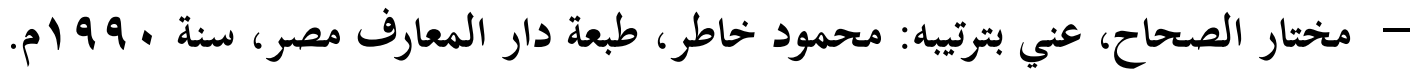

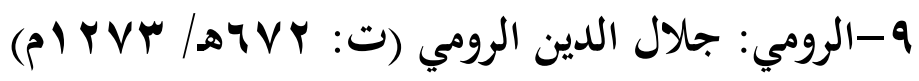

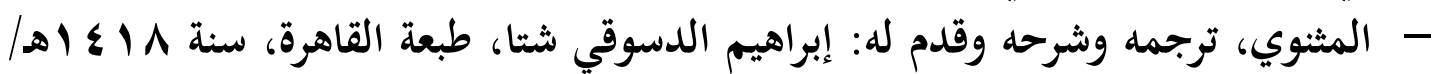

م) 199V

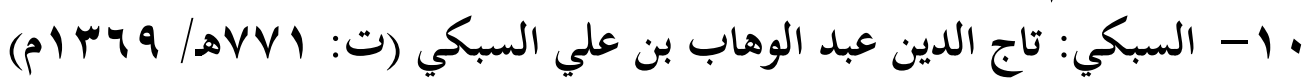

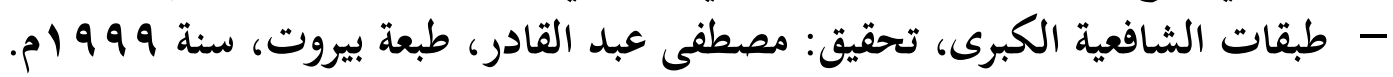

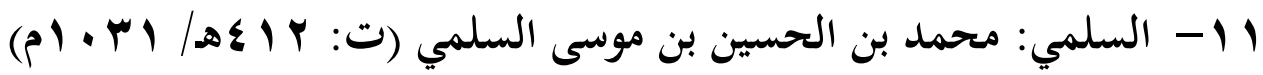

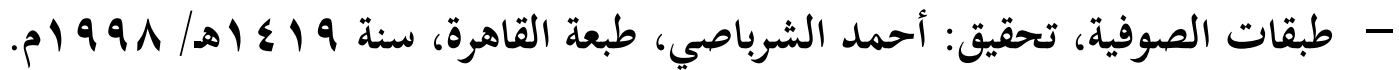

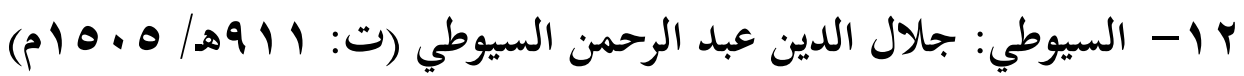


- المكنون في مناقب ذي النون، تحقيق: عبد الرحمن حسن محمود، طبعة القاهرة، سنة

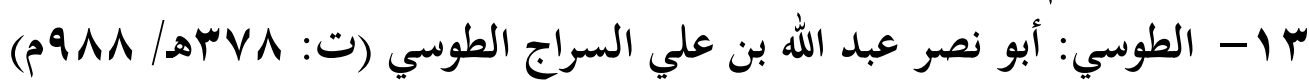
- اللمع في التصوف، اعتنى بنسخه وتصحيحه: رنولد ألن نيكلسون، طبعة ليد اليدن، سنة النه

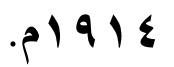

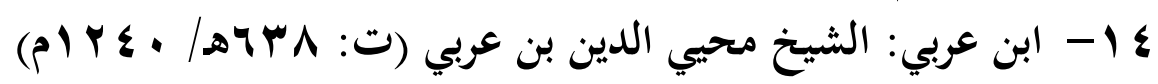

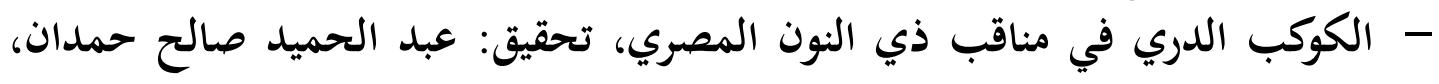

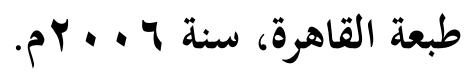

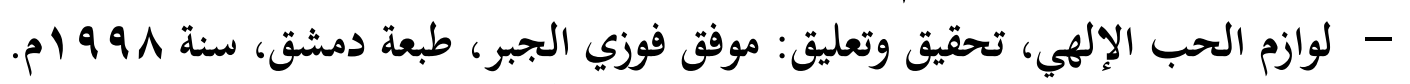

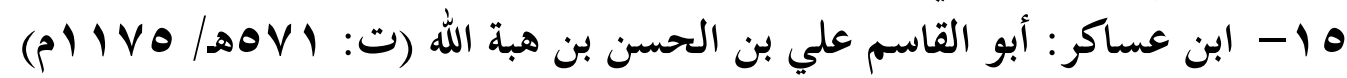

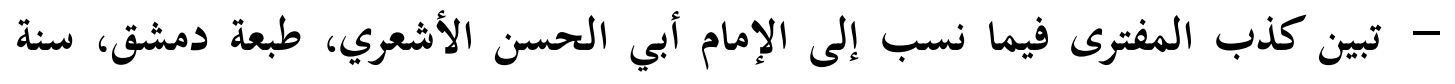
اله

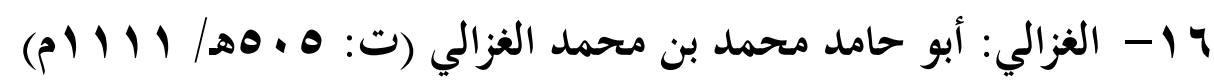

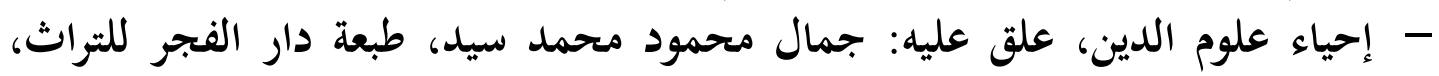

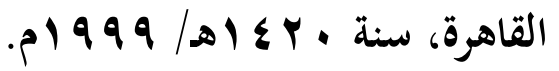

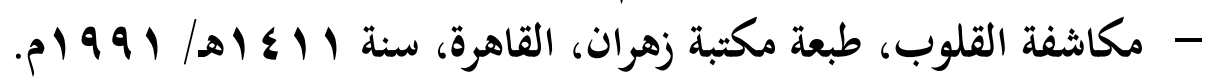
IV

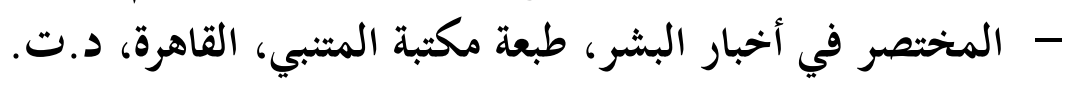

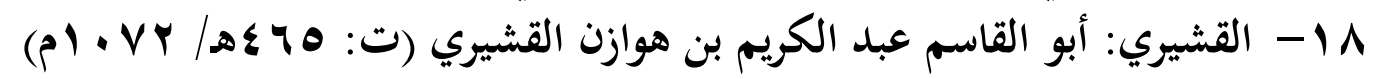

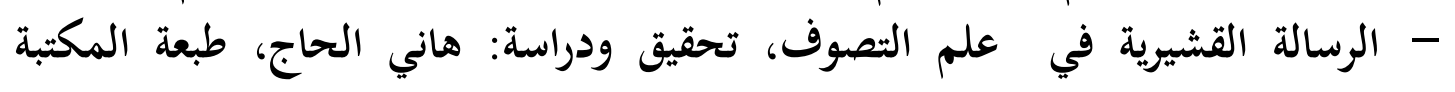

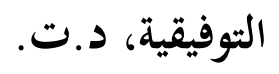

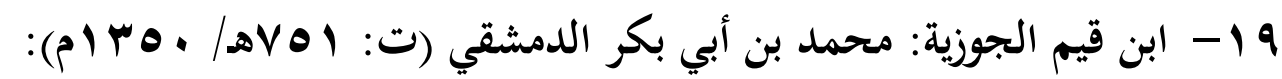

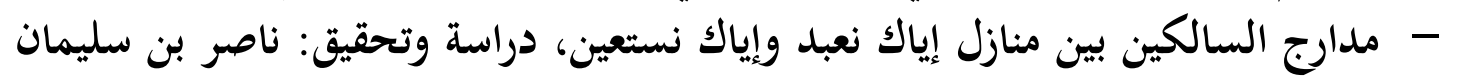

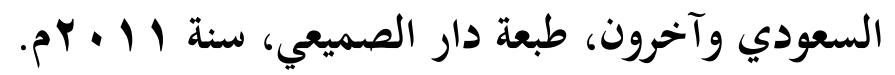

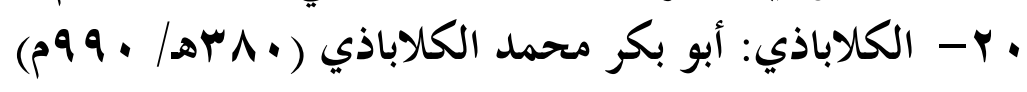

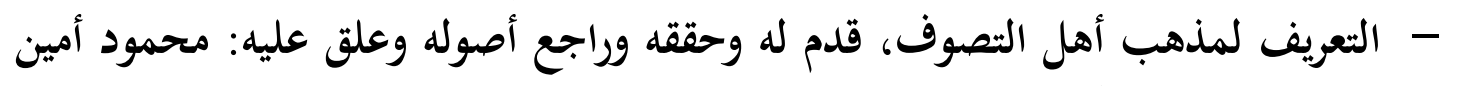

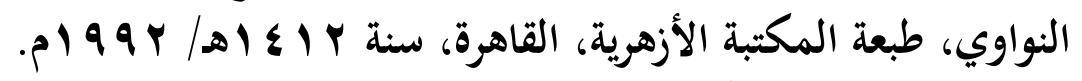

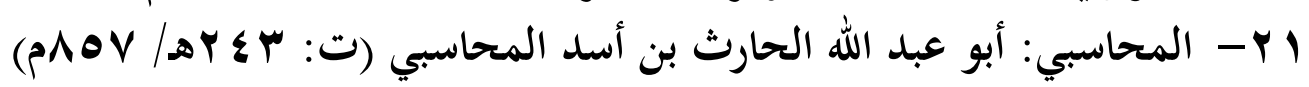

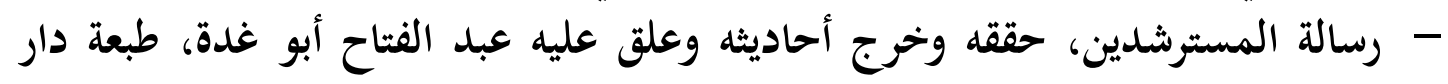

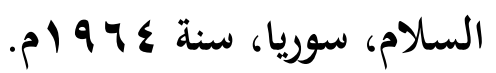




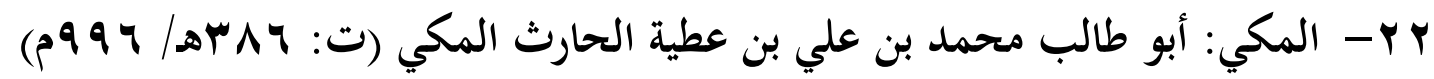

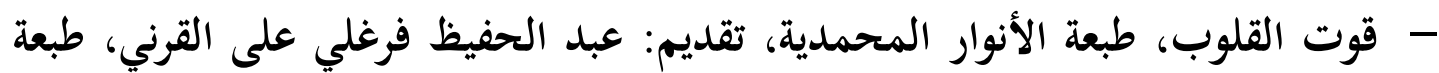

\section{م) 910}

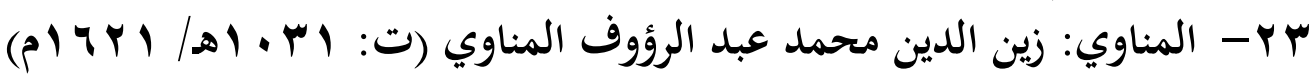

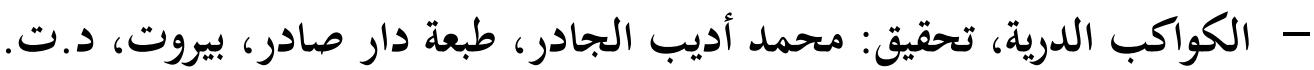

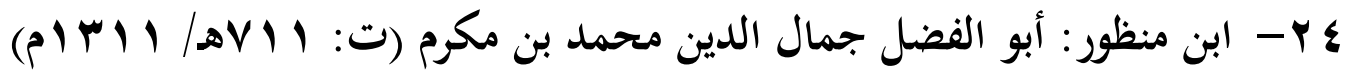

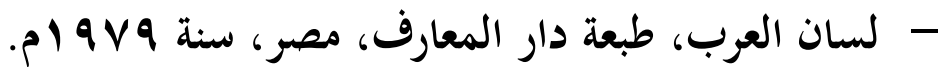
هץ - الهجويري: أبو الحسن علي بن عثمان بن أبي علي الجلابي (ت: حوالي سنة هـ ــهـ| (p) V V - كشف المحجوب، ترجمة وتحقيق: إسعاد عبد الهادي قنديل، مراجعة: أمين عبد الإدماديد

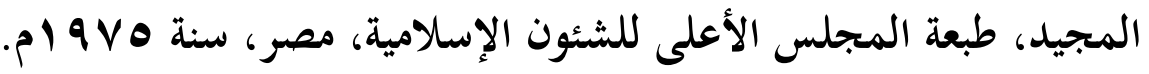

$$
\text { المراجع: جرجي زيدان: }
$$

- تاريخ آداب اللغة العربية، طبعة دار الهلال، القاهرة، د.ت.

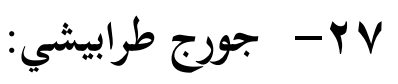

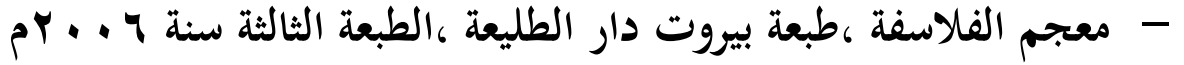

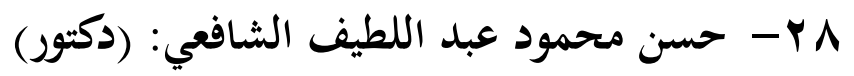

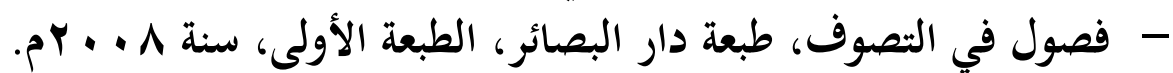

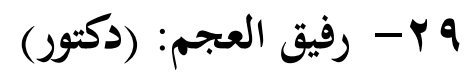

- موسوعة مصطلحات التصوف الإسلامي، طبعة بيروت، لبنان، سنة 999 ام ام.

$$
\text { • r- رينولد ـ أ. نيكلسون: }
$$

- في التصوف الإسلامي وتاريخه، نقلها إلى العربية وعلق عليها أبو العلا عفيفي، طبعة الت التهرة

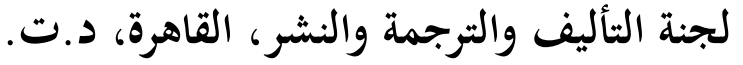

$$
\text { اب- زكي مبارك: (دكتور) }
$$

- التصوف الإسلامي في الأدب والأخلاق، الطبعة الثانية، دمشق، سنة بrأ اهـ|

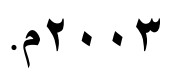

$$
\text { r r ب- عبد الحليم محمود: (دكتور) }
$$

- سلطان العارفين أبو زيد البسطامي، طبعة القاهرة، د.ت.

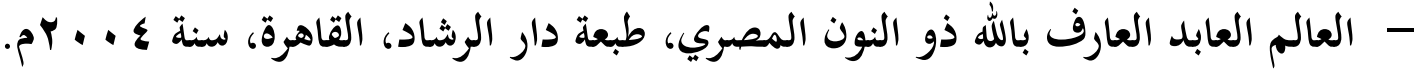
r ب- عبد الرحمن بدوي: (دكتور) 
- شهيدة العشق الإلهي (رابعة العدوية)، طبعة النهضة المصرية، سنة به 9 ام.

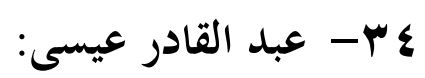

- حقائق عن التصوف، طبعة مطابع الديوان، نورويش، إنجلترا، د.ت.

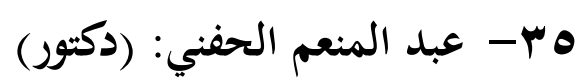

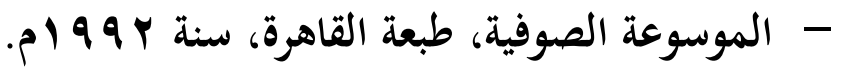
- - رابعة العدوية إمامة العاشقين والمحزونين، طبعة دار الرشاد، القاهرة، الطبعة الثانية، سنة

$$
\begin{aligned}
& \text { (1997 } 997 \\
& \text { باب- أبو العلا عفيفي: (دكتور) } \\
& \text { - التصوف والثورة الروحية في الإسلام، طبعة دار الشعب، بيروت، د.ت. }
\end{aligned}
$$

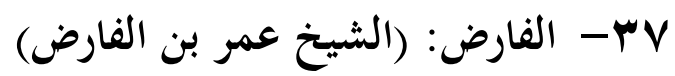

- ديوان الإمام العارف الشيخ عمر بن الفارض، مطبعة الحسينية المصرية، سنة

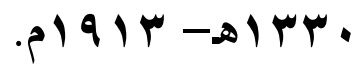

^ץ- ليلى زكي قطب (دكتورة) - رواشا محمود علي (دكتورة)

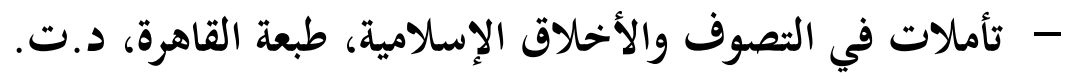

$$
\text { 9 - م- محمد شلبي شتيوي (دكتور) }
$$

- التصوف والصوفية في ضوء النصوص الدينية الدئية والبراهين العقلية، الطبعة الأولى، دار

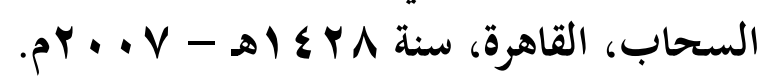

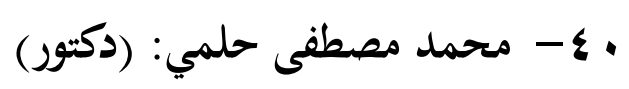

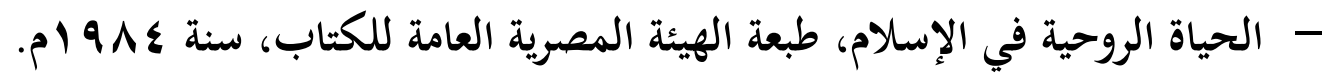

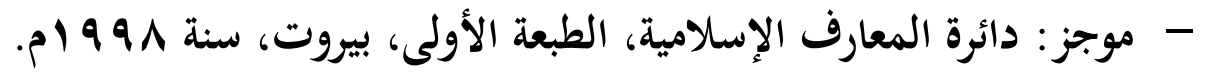

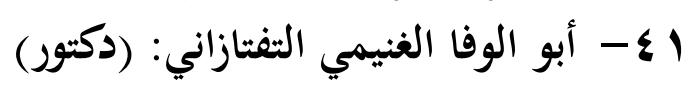

- مدخل إلى التصوف الإسلامي، طبعة دار الثقافة للنشر والثوزيع، القاهرة،

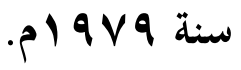

